Universidade de São Paulo

Faculdade de Medicina de Ribeirão Preto

Departamento de Genética

PAPEL DE NOTCH E NF-KB NA REGULAÇÃO DE FATORES DE TRANSCRIÇÃO DURANTE A DIFERENCIAÇÃO IN VITRO DE CÉLULAS T A PARTIR DE CÉLULAS PROGENITORAS HEMATOPOÉTICAS CD34 ${ }^{+}$

Josiane Lilian dos Santos Schiavinato

Ribeirão Preto - SP

2011 


\author{
Universidade de São Paulo \\ Faculdade de Medicina de Ribeirão Preto \\ Departamento de Genética
}

Josiane Lilian dos Santos Schiavinato

\title{
PAPEL DE NOTCH E NF-KB NA REGULAÇÃO DE FATORES DE TRANSCRIÇÃO DURANTE A DIFERENCIAÇÃO IN VITRO DE CÉLULAS T A PARTIR DE CÉLULAS PROGENITORAS HEMATOPOÉTICAS CD34 ${ }^{+}$.
}

Dissertação apresentada ao Programa de PósGraduação em Genética da Faculdade de Medicina de Ribeirão Preto da Universidade de São Paulo, como parte dos pré-requisitos para obtenção do título de Mestre em Genética.

Área de concentração: Genética

Orientador: Prof. Dr. Rodrigo Alexandre Panepucci 
Autorizo a reprodução e divulgação total ou parcial deste trabalho, por qualquer meio convencional ou eletrônico, para fins de estudo ou de pesquisa, desde que citada a fonte.

FICHA CATALOGRÁFICA

Schiavinato, Josiane Lilian dos Santos

Papel de Notch e NF-kB na regulação de fatores de transcrição durante a diferenciação in vitro de células $\mathrm{T}$ a partir de células progenitoras hematopoéticas CD $34^{+}$.

Ribeirão Preto, 2011.

Dissertação de Mestrado, apresentada à Faculdade de Medicina de Ribeirão Preto/USP. Área de concentração: Genética

Orientador: Panepucci, Rodrigo Alexandre

1. Células-tronco hematopoéticas. 2. Células CD34 ${ }^{+}$.

3. Sangue de cordão umbilical. 4. Via NF-kB. 5. Via NOTCH.

6. Células estromais de camundongos OP9. 


\section{FOLHA DE APROVAÇÃO}

\section{Josiane Lilian dos Santos Schiavinato}

Papel de Notch e NF-kB na regulação de fatores de transcrição durante a diferenciação in vitro de células T a partir de células progenitoras hematopoéticas CD34 ${ }^{+}$.

Dissertação apresentada ao Programa de PósGraduação em Genética da Faculdade de Medicina de Ribeirão Preto da Universidade de São Paulo, como parte dos pré-requisitos para obtenção do título de Mestre em Genética.

Área de concentração: Genética

Aprovado em

\section{Banca examinadora:}

Prof. Dr.

Instituição:

Assinatura:

Prof. Dr.

Instituição:

Assinatura:

Prof. Dr.

Instituição:

Assinatura: 
Dedico esse trabalho aos meus pais Luiz e Márcia, pelo amor e incentivo para a realização dos meus sonhos. 


\section{AGRADECIMENTOS}

Primeiramente gostaria de agradecer a Deus pela vida, pela saúde e por todos os aprendizados obtidos durante essa caminhada, pois sem eles eu não teria aprendido tanto, e não seria a pessoa que sou hoje.

Ao Prof. Dr. Rodrigo Alexandre Panepucci pela receptividade em seu laboratório, pelas idéias e discussões, por sua paciência, por sua confiança em mim, pela orientação e amizade.

À MATER de Ribeirão Preto, à enfermeira Maria Fernanda Lopes, que realizou todas as coletas de sangue, e a todas as mães que doaram o sangue de cordão umbilical de seus filhos para que essa pesquisa pudesse ser realizada.

As técnicas do laboratório de Biologia Molecular I e Hematologia Amélia Goes de Araújo, Marli Haydee Tavella, Cláudia Helena Avelar, Elizabete Tavares Figueiredo Auddino e Júlia Mieko Yoshida Komoto, que me receberam muito bem no laboratório e sempre colaboraram para a realização desse trabalho.

Aos amigos que fiz no laboratório de Hematologia Felipe Araújo, Francisco Careta, Lucila Oliveira, Carolina Dias, Fernanda Trigo, Mariane Fráguas, Rodrigo Hadadd, Antonio Roberto, Mariana Benício, Fábio Morato e Sabrina Cuevas que participaram intensamente da minha vida durante essa importante etapa, colaborando com sugestões, discussões ou mesmo com a amizade e companheirismo durante essa longa jornada. 
Aos meus queridos pais, Luiz e Márcia, por viabilizarem e investirem em minha formação, por acreditarem em mim, pelo amor e apoio nos momentos mais difíceis, sempre tento muita paciência comigo.

À minha irmã Patrícia, ao meu cunhado Rafael, e ao amor da minha vida Gustavo, pelo apoio, carinho, paciência e compreensão em todos os momentos.

Aos meus avós que sempre estiveram do meu lado, auxiliando nos momentos mais complicados, sempre incentivando com pensamentos positivos e com sua fé em Deus.

Obrigada ainda aos amigos e colaboradores do Hemocentro e do Laboratório de Hematologia II, especialmente à Patrícia, à Camila e à Aglair pelo auxílio com as análises de citometria de fluxo, e ao Reginaldo e Natália da Criobiologia.

À Susie e a Maria Aparecida, secretarias do departamento de Genética, que sempre se mostraram muito solicitas para esclarecimentos de dúvida e para resolução dos meus problemas.

À FAPESP pela bolsa concedida, a FAEPA e ao Hemocentro pelo auxílio financeiro junto aos congressos.

E a todos os demais que de forma direta ou indiretamente colaboraram de alguma forma com a realização desse trabalho e com a concretização de um grande sonho. 
“Apesar dos nossos defeitos, precisamos enxergar que somos pérolas únicas no teatro da vida e entender que não existem pessoas de sucesso e pessoas fracassadas. O que existem são pessoas que lutam pelos seus sonhos ou desistem deles." 


\section{RESUMO}

Schiavinato, J.L.S Papel de Notch e NF-kB na regulação de fatores de transcrição durante a diferenciação in vitro de células $\mathrm{T}$ a partir de células progenitoras hematopoéticas CD34 ${ }^{+}$. Dissertação de Mestrado - Faculdade de Medicina de Ribeirão Preto, Universidade de São Paulo, Ribeirão Preto, 2011.

Em estudos anteriores desenvolvidos por este grupo de pesquisa uma expressão mais elevada de alvos transcricionais e componentes da via NF-kB, bem como altos níveis de NOTCH1, foi identificada em células-tronco hematopoéticas $(\mathrm{CTH}) \mathrm{CD}^{+} 4^{+}$de sangue de cordão umbilical (SCU) quando comparadas às $\mathrm{CTH} \mathrm{CD}^{+} 4^{+}$de medula óssea $(\mathrm{MO})$. Este grupo verificou ainda, por comparação das células $\mathrm{CD}^{+} 4^{+}$com as $\mathrm{CD}_{133^{+}}$(mais primitivas) que diversos fatores de transcrição (FT) envolvidos com o potencial de hemangioblasto, com a autorenovação das CTH, e com a diferenciação linfóide; como: RUNX1/AML1, GATA3, USF1, TAL1/SCL, HOXA9 e HOXB4 apresentaram-se mais expressos em células mais primitivas. A potencial participação das vias Notch e NF-kB na regulação destes FT tem importância conceitual e prática no entendimento da biologia das $\mathrm{CTH}$, e dos processos envolvidos na diferenciação destas células. Com isto em vista, este projeto teve como objetivo, estudar o papel da via NF-kB e da via Notch na regulação destes FT. Para isso, um modelo experimental in vitro, de diferenciação de $\mathrm{CTH} \mathrm{CD}_{3} 4^{+}$em linfócitos $\mathrm{T}$, foi utilizado e a influência de fatores agonistas e inibidores farmacológicos destas vias, foram avaliados por citometria de fluxo e PCR em tempo real. Nossos resultados evidenciam o papel da via Notch na regulação transcricional de HOXB4 e GATA3 em células-tronco hematopoéticas CD34 ${ }^{+}$ humanas, o que foi confirmado com base na expressão dos alvos diretos de Notch (HEY1 e HES1). Notamos ainda, que a expressão dos transcritos HES1, GATA3 e HOXB4 é prejudicada pela síntese protéica das $\mathrm{CTH}$, uma vez que quando empregamos o prétratamento com a droga CHX há aumento da transcrição dos mesmos. Também podemos inferir que a ação do TNF- $\alpha$ é positiva sobre esses transcritos, já que quando o utilizamos há elevação do nível de expressão desses transcritos, com exceção a HES1. Em relação ao cocultivo das $\mathrm{CTH}$ com as células estromais de camundongos, verificamos que apenas a linhagem OP9-DL1 detém a capacidade de promover a diferenciação celular T, e isso foi comprovado pelo surgimento de células comprometidas com a linhagem linfocítica $T$, através

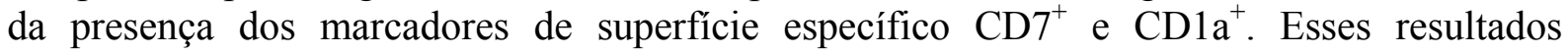
auxiliarão na compreensão dos mecanismos moleculares de regulação transcricional envolvidos não apenas na diferenciação de linfócitos $\mathrm{T}$, mas também na manutenção de um estado mais primitivo das CTH. Este conhecimento pode vir a contribuir com o desenvolvimento ou otimização de protocolos laboratoriais visando à expansão de CTH ou geração de células T para usos terapêuticos.

Palavras-chaves: Células-tronco hematopoéticas; Células $\mathrm{CD}_{34}^{+}$; Sangue de cordão umbilical; Via NF-kB; Via Notch; Células estromais de camundongos OP9. 


\begin{abstract}
Schiavinato, JLS Role of Notch and NF-kB in the regulation of transcription factors during in vitro differentiation of $\mathrm{T}$ cells from $\mathrm{CD} 34^{+}$hematopoietic progenitor cells. Faculdade de Medicina de Ribeirão Preto, Universidade de São Paulo, Ribeirão Preto, 2011.

In previous studies by this research group a higher expression of transcriptional targets and components via NF-kB, as well as high levels of NOTCH1, was identified in hematopoietic stem cells (HSC) CD34 + cells from umbilical cord blood (UCB) compared to CD34 + hematopoietic stem cells from bone marrow (BM). This group also found, by comparing the CD34 + cells with CD133 + (more primitive) that several transcription factors (TF) involved in the potential of hemangioblast, with self-renewal of hematopoietic stem cells and to differentiated lymphocytic; as Runx1 / AML1, GATA3, USF1, TAL1/SCL, HOXB4 and HOXA9 were more expressed in more primitive cells. The potential involvement of Notch signaling pathways and NF-kB in the regulation of FT has conceptual and practical importance in understanding the biology of HSC, and the processes involved in differentiation of these cells. With this in mind, this project aimed to study the role of NF-kB pathway and Notch signaling in the regulation of FT. For this, an experimental model in vitro differentiation of CD34 + hematopoietic stem cells into T lymphocytes, was used and the influence of pharmacological agonists and inhibitors of these pathways were evaluated by flow cytometry and real-time PCR. Our results highlight the role of Notch signaling in the transcriptional regulation of GATA3 and HOXB4 in hematopoietic stem cells CD34 + human, which was confirmed based on the expression of direct targets of Notch (HES1 and HEY1). We also note that the expression of transcripts HES1, GATA3 and HOXB4 protein synthesis is hampered by the HSC, since when we use the pre-treatment with the drug there $\mathrm{CHX}$ increased transcription thereof. We can also infer that the action of TNF- $\alpha$ is positive about these transcripts, since when we use it for raising the level of expression of these transcripts, except the HES1. In relation to the HSC coculture with stromal cells of mice, we found that only the line-DL1 Op9 has the ability to promote $\mathrm{T}$ cell differentiation, and this was evidenced by the appearance of cells committed to the $\mathrm{T}$ lymphocyte lineage, through the presence of specific surface markers CD7 + and CD1a + . These results will help understand the molecular mechanisms of transcriptional regulation involved not only in the differentiation of $\mathrm{T}$ lymphocytes, but also in maintaining a more primitive state of HSC. This knowledge may contribute to the development or optimization of laboratory protocols aimed at the expansion of HSC or generation of T cells for therapeutic use.
\end{abstract}

Keywords: Hematopoietic stem cells, CD $34^{+}$cells, umbilical cord blood; Via NF-kB; Via Notch; stromal cells of mice OP9. 


\section{LISTA DE FIGURAS}

Figura 1. Células-tronco hematopoéticas podem originar duas linhagens celulares, a linhagem mielóide e a linfóide. A primeira origina os eritrócitos, megacariócitos, macrófagos, monócitos e granulócitos enquanto, a linhagem linfóide forma os linfócitos T, B e NK.

(Página 18)

Figura 2. Esquema da sinalização da via Notch. Mediante a interação com o ligante, o receptor de Notch é clivado pelo complexo $\gamma$-secretase, resultando na liberação do domínio intracelular (NICD) que é transportado ao núcleo da célula. Esse se liga a um complexo de proteínas contendo a proteína ligante de DNA RBP-J/CSL e, após liberação de correpressores (CoR) e recrutamento de coativadores (CoA), inicia-se a transcrição de genes alvos (como HEY1 e HES1). O local de atuação da droga DAPT, que inibe a liberação do NICD através da inibição da clivagem mediada pela $\gamma$-secretase, também é evidenciado no esquema.

(Página 26)

Figura 3. Esquema ilustrativo do processo de diferenciação celular a partir das células-tronco hematopoéticas $\mathrm{CD} 4^{+}$ao longo da linfopoiese, destacando os principais marcadores de superfícies específicos de cada estágio da diferenciação. Inicialmente, há o aparecimento dos marcadores CD7 e CD1a, em seguida do CD4 e CD8, até a formação das células linfocíticas T $\mathrm{CD}^{+} \mathrm{CD}^{+}$e $\mathrm{CD} 8^{+} \mathrm{CD} 3^{+}$ simples positivas.

(Página 27)

Figura 4. Mecanismo de sinalização da via $N F-\kappa B$, evidenciando o local de ação de um dos inibidores farmacológicos desta via, o BAY (que impede a fosforilação, e consequentemente inibe a transcrição dos alvos dessa via).

(Página 29)

Figura 5. Esquema ilustrativo do isolamento imunomagnético das células-tronco hematopoéticas $\mathrm{CD}^{+} 4^{+}$a partir do sangue de cordão umbilical (SCU), destacando as principais etapas durante esse procedimento (separação por densidade de gradiente com Ficoll-Hypaque; isolamento das células mononucleares; e separação imunomagnética das $\mathrm{CTH} \mathrm{CD} 34^{+}$).

(Página 36)

Figura 6. Estratégia adotada para a determinação da expressão do marcador CD34 em citometria de fluxo. Durante a aquisição das células, foi desenhada uma gate na população de progenitores linfocitários (R1), estabelecida com base nos parâmetros de tamanho (FSC) por granularidade (SSC) (A). Os dot plots revelam a marcação dos eventos selecionados por R1, para os isotipos controles IgG1/IgG2a (B) e para o sinal de CD34-PerCP (C).

(Página 37)

Figura 7. Esquema representante do processamento do SCU, do cultivo das células OP9, além do preparo e manutenção do cocultivo das células $\mathrm{CD}^{+} 4^{+}$com as OP9, sempre em presença de IL-7 e Flt3-L, seguindo a linha temporal, até o momento de coleta das amostras e extração do RNA total.

...(Página 40)

Figura 8. Esquema de montagem da placa de cocultivo, com as células estromais (OP9-GFP e OP9-DL1) e CTH CD $34^{+}$e, a distribuição de todos os tratamentos empregados neste experimento (DAPT $10 \mu \mathrm{M}$, $0,25 \mathrm{ng} / \mathrm{ml}$ de TNF- $\alpha$ e CHX).

Figura 9. Análise da expressão do marcador de superfície DL1, nas células estromais de camundongo OP9GFP e OP9-DL1. Podemos observar que as primeiras praticamente não expressam tal marcador (aproximadamente 10\%), enquanto, que as células OP9-DL1 evidenciaram uma taxa de expressão do marcador de aproximadamente $90 \%$, independentemente da passagem em que as células estromais se encontravam.

Figura 10. Análise da pureza das células-tronco hematopoéticas $C D 34^{+}$após separação imunomagnética a partir de amostra de sangue de cordão umbilical. 
Figura 11. Imagem representativa da eficiência das sondas empregadas neste trabalho (curvas referentes à sonda GAPDH). Podemos verificar que não houve amplificação das sondas humanas para as condições em que apenas as células de camundongo (tanto OP9-GFP, quanto OP9-DL1) estavam presentes (indicado pelo ruído). Todas as demais condições apresentaram curva de amplificação, sendo que a curva 1 representa a amostra de $\mathrm{CD} 34^{+}$pura; a curva 2 representa as $\mathrm{CD} 34^{+}$em presença da mesma quantidade das OP9-DL1; a curva 3 indica a diluição de 10x; a curva 4 representa a diluição de 100x; a curva 5 ilustra a diluição de 1000x; a curva 6 corresponde à diluição de 10000x; e a curva 7 representa a diluição de $100000 x$. Podemos ainda calcular a eficiência das sondas através do slope (fornecido pelo programa do Real Time PCR). Para todas as sondas utilizadas, a eficiência foi superior a $100 \%$.

(Página 47)

Figura 12: Destino das CTH CD34 $4^{+}$cocultivadas com as células estromais murinas OP9-GFP e OP9-DL1 na presença das citocinas IL-7 e Flt3-L. Evidenciando que o cocultivo das CTH com a linhagem OP9-GFP leva a produção de células B, enquanto que o cocultivo com a linhagem OP9-DL1 leva a produção de células $\mathrm{T}$.

Figura 13. Análise da diferenciação das $\mathrm{CTH} C D 34^{+}$em linfócitos $\mathrm{T}$ por citometria de fluxo. As $\mathrm{CTH}$ $\mathrm{CD} 34^{+}$selecionadas imunomagneticamente de sangue de cordão umbilical foram cocultivadas com OP9-GFP e OP9-DL1 e a expressão de CD7 e CD1a foi avaliada após o $12^{\circ}$ dia. Para isso, utilizamos a seguinte marcação: um tubo contendo os controles inespecíficos IgG1 APC e IgG1 PerCP, um tubo contendo anti-CD45 APC e anti-CD34 PerCP, um tubo contendo IgG1 FITC e IgG1 PE e outro contento anti-CD1a PE e anti-CD7 FITC a fim de traçar as gates. As porcentagens presentes em cada quadrantes representam o total de células de cada tipo.

(Página 49)

Figura 14. Dependência da via de sinalização Notch para diferentes fatores transcricionais (HEY1, HES1, GATA3 e HOXB4), evidenciado pela maior taxa de expressão desses transcritos quando em presença do ligante de Notch, Delta-like 1, e, confirmado pela repressão desses fatores em presença de DAPT (droga inibitória da via de sinalização Notch), com exceção de GATA3, o qual não é reprimido em presença do inibidor. Além do papel positivo desempenhado pela citocina TNF- $\alpha$ sobre a transcrição dos fatores HEY1, GATA3 e HOXB4.

(Página 70)

Figura 15. Esquema ilustrativo da dependência da via de sinalização Notch para diferentes fatores transcricionais (HEY1, HES1, GATA3 e HOXB4). Evidenciado pela maior taxa de expressão desses transcritos quando em presença do ligante de Notch, Delta-like 1, e confirmado pela repressão desses fatores em presença de DAPT (droga inibitória da via de sinalização Notch). Além do papel desempenhado pela CHX sobre a transcrição desses fatores, evidenciando que para a maioria dos fatores avaliados há alguma proteína sintetizada pelas $\mathrm{CTH} \mathrm{CD} 34^{+}$, que reprimem sua transcrição.

(Página 70)

Figura 16. O modelo indica que as proteínas $\mathrm{IkB} \alpha$ são recrutadas pelo promotor de HES1, juntamente com elementos repressores, levando a repressão de sua transcrição. E que em presença de TNF- $\alpha$, há liberação do sistema, pois as IKKs são recrutadas para o promotor, resultando em liberação das IkB $\alpha$, e, consequentemente, causando a ativação transcricional desse gene. 


\section{LISTA DE GRÁFICOS}

Gráfico 1. Análise da diferenciação celular das células-tronco hematopoéticas $\mathrm{CD}_{3} 4^{+}$em cocultivo com as células OP9-GFP e OP9-DL1, com 12 e 24 dias de cocultivo. Avaliando a expressão dos marcadores de superfície CD7 e CD1a. Além de evidenciar a porcentagem de células comprometidas com a linhagem linfocítica $\mathrm{T}\left(\mathrm{CD} 7^{+} \mathrm{CD} 1 \mathrm{a}^{+}\right)$.

(Página 50)

Gráfico 2. Análise da diferenciação celular das células-tronco hematopoéticas $\mathrm{CD}_{3} 4^{+}$em cocultivo com as células OP9-DL1 durante 12 dias e 24 dias, em presença do pré-tratamento por 12 horas com TNF- $\alpha$. Avaliando a expressão dos marcadores de superfície CD7 e CD1a, além de evidenciar a porcentagem de células comprometidas com a linhagem linfocítica $\mathrm{T}\left(\mathrm{CD} 7^{+} \mathrm{CD} 1 \mathrm{a}^{+}\right)$.

(Página 51)

Gráfico 3. Avaliação temporal da transcrição de HEY1. A expressão do gene alvo da via Notch (HEY1) foi avaliada em diferentes tempos (2, 12, 24 e 48 horas) de cocultivo, utilizando as respectivas condições de cocultivo das células-tronco hematopoéticas $\mathrm{CD} 34^{+}$com as células OP9-GFP como referência para o cálculo da expressão relativa das condições de cocultivo das CTH com as OP9-DL1.

..(Página 52)

Gráfico 4. Determinação da concentração inibitória da droga DAPT. A ação da droga DAPT em diferentes concentrações $(10 \mu \mathrm{M}, 25 \mu \mathrm{M}, 50 \mu \mathrm{M}$ e $100 \mu \mathrm{M})$ foi avaliadas após 12 horas de cocultivo para determinar a concentração mínima suficiente para inibir a transcrição do alvo conhecido da via Notch (HEY1).

(Página 53)

Gráfico 5. Análise da expressão do transcrito HEY1, evidenciando a dependência da via de sinalização Notch para sua transcrição, através do cocultivo das CTH CD34 ${ }^{+}$com as células OP9-DL1 (células OP9 que foram transduzidas com o ligante de Notch, Delta-like 1), e tendo confirmação pelo uso do inibidor da via Notch (DAPT).

(Página 54)

Gráfico 6. A análise da transcrição de HEY1, além de ser dependente da via Notch, evidencia independência da síntese protéica para a ativação da expressão desse fator transcricional.

(Página 55)

Gráfico 7. O cocultivo conjunto das CTH pré-tratadas com CHX e o uso da droga DAPT indicam que as proteínas sintetizadas de novo atuariam positivamente na transcrição deste fator.

(Página 56)

Gráfico 8. Avaliando o papel desempenhado por TNF- $\alpha$, na transcrição de HEY1, aparentemente não observamos atuação deste, nem na presença, nem em ausência do pré-tratamento com CHX. .(Página 56)

Gráfico 9. Papel positivo de TNF- $\alpha$ na expressão de HEY1, comprovado através do tratamento concomitante do cocultivo com TNF- $\alpha$ e DAPT (inibidor da via Notch).

(Página 57)

Gráfico 10. A ação do pré-tratamento com CHX nas CTH conjuntamente com TNF- $\alpha$, evidencia que a inibição da síntese protéica implica em redução na expressão de HEY1, mesmo com a inibição da via Notch, comprovando o efeito positivo de TNF- $\alpha$, mediada por proteínas sintetizadas e de forma independente de Notch.

(Página 57)

Gráfico 11. A análise da transcrição de HES1, no cocultivo das CTH CD34 ${ }^{+}$com a linhagem OP9-DL1 (portadora do ligante de Notch), evidencia a participação da via de sinalização Notch no controle transcricional desse fator, e esse controle é confirmado através do uso de DAPT (inibidor de Notch). (Página 58)

Gráfico 12. O pré-tratamento das $\mathrm{CTH}$ com a droga $\mathrm{CHX}$ permite inferir que a inibição da síntese protéica atua de forma positiva na transcrição de HES1. 
Gráfico 13. A ação de DAPT nas células CTH que receberam o pré-tratamento com a CHX evidencia que as proteínas sintetizadas não atuam de forma direta sobre a via Notch.

(Página 59)

Gráfico 14. O TNF- $\alpha$ comportou-se de forma bastante heterogênea em relação à transcrição de HES1, tanto na presença, quanto na ausência da via Notch.

(Página 60)

Gráfico 15. A ação da $\mathrm{CHX}$, possivelmente, seria contrabalanceada pela indução da síntese protéica, com efeito negativo sobre a transcrição de HES1, mediada pelo TNF- $\alpha$. Evidenciando efeito negativo de TNF- $\alpha$ sobre a transcrição de HES1, independente da via Notch, e mediado por proteínas sintetizadas de novo.

(Página 60)

Gráfico 16. Análise da expressão de GATA3, evidenciando a participação parcial da via Notch no controle dessa transcrição, pois há indução desse fator no cocultivo com as OP9-DL1 (portadoras do ligante de Notch), porém em ausência da via Notch (com o uso de DAPT) não há a repressão.

(Página 61)

Gráfico 17. Observamos efeito positivo de TNF- $\alpha$, e CHX sobre a transcrição de GATA3 e, principalmente, do uso concomitante dos mesmos, evidenciando que a ação positiva de TNF- $\alpha$, é independente da síntese de novo de proteínas e, portanto, mediada por mecanismos de sinalização presentes na célula.

(Página 62)

Gráfico 18. A ação conjunta do pré-tratamento com CHX nas CTH, DAPT e TNF- $\alpha$ evidencia que o efeito positivo de TNF- $\alpha$ ocorre de forma dependente da via de sinalização Notch.

(Página 62)

Gráfico 19. Análise da expressão do HOXB4 ao longo do tempo (12h, 36h, 60h, 84h, 108h e 132h) de cocultivo das $\mathrm{CTH} \mathrm{CD} 34^{+}$em presença das células de camundongo (OP9-GFP e OP9-DL1). .(Página 63)

Gráfico 20. A análise da transcrição de HOXB4, através do cocultivo das $\mathrm{CTH}$ CD $34^{+}$com as linhagens OP9-GFP e OP9-DL1, evidenciou a participação da via de sinalização Notch no controle transcricional desse fator, e este é confirmado pelo uso de DAPT.

(Página 64)

Gráfico 21. Ação positiva do TNF- $\alpha$ sobre a transcrição de HOXB4, de maneira dependente da via Notch, uma vez que em presença da droga DAPT, não observamos aumento na expressão de HOXB4 mesmo em presença de TNF- $\alpha$.

(Página 65)

Gráfico 22. A ação positiva do TNF- $\alpha$, ocorre de forma dependente da síntese protéica, pois em presença de CHX o efeito de TNF- $\alpha$ deixa de ser notado.

(Página 65)

Gráfico 23. A regulação transcricional de HOXB4 é, indiretamente, mediada pela via Notch, pela ligação do complexo NICD/CSL à região promotora de HOXB4.

(Página 66)

Gráfico 24. Análise de expressão de RELA, RELB, NFKB1 e NFKB2 em CTH CD34 $4^{+}$pré-tratadas ou não com CHX, cocultivadas com células estromais de camundongos OP9-GFP e OP9-DL1, em presença ou ausência de DAPT e TNF- $\alpha$, e em presença simultânea dos mesmos.

(Página 67) 


\section{LISTA DE ABREVIATURAS E SIGLAS}

- $\mathrm{ACD}=$ do inglês "Acid Citrate Dextrose"

- $\mathrm{ADAM}=$ a disintegrin and metalloprotease

- Anti-CD34 = referente ao anticorpo contra o antígeno CD34

- $\mathrm{BAY}=$ droga inibitória da via de sinalização NF- $\mathrm{kB}$

- $\mathrm{CD}=$ do inglês "Cluster of Differentiation"

- $\mathrm{CD}_{4}{ }^{+}=$referente às células que expressam o marcador CD34

- $\quad \mathrm{DNA}=$ do inglês "Complementary Desoxiribonucleic Acid"

- $\mathrm{CHX}=$ cycloheximide

- $\quad \mathrm{CMN}=$ Células Mononucleares

- $\mathrm{CSL}=\mathrm{CBF} 1 / \mathrm{Su}(\mathrm{H}) / \mathrm{Lag}-1$

- $\quad \mathrm{CT}=$ célula-tronco

- $\quad \mathrm{CTA}=$ célula-tronco adulta

- $\mathrm{CTE}=$ célula-tronco embrionária

- $\quad \mathrm{CTH}=$ Células-tronco hematopoéticas

- $\mathrm{DAPT}=\gamma$-secretase (droga inibitória da via de sinalização Notch)

- $\quad \mathrm{DECH}=$ Doença do Enxerto Contra o Hospedeiro

- $\mathrm{DEPC}=$ dietilpirocarbonato

- $\quad$ DL1 = ligante de Notch, Delta-Like 1

- $\mathrm{DNA}=$ do inglês "Desoxirribonucleic Acid"

- FACS = do inglês "Fluorescence-Activated Cell Sorter"

- $\quad \mathrm{FITC}=$ do inglês "Fluorescein Isothiocyanate"

- Flt3-L = do inglês "fms-like tyrosine kinase 3 ligand"

- $\quad \mathrm{FSC}=$ do inglês "Forward Scatter"

- $\mathrm{FT}=$ fator de transcrição

- $\mathrm{HES}=$ hairy and enhancer of split

- $\mathrm{HEY}=$ Hes-related repressor

- $\mathrm{HLA}=$ do inglês "Human Leukocyte Antigen"

- $\quad$ IgG1 = Imunoglobulina Gama Isotipo 1

- $\quad \operatorname{IgG} 2 \mathrm{~A}=$ Imunoglobulina Gama Isotipo $2^{\mathrm{a}}$

- $\quad$ IL-7 = interleucina 7

- $\mathrm{MO}=$ medula óssea

- $\quad \mathrm{NF}-\mathrm{kB}=$ do inglês "Nuclear Factor kappa B"

- $\quad \mathrm{NICD}=$ domínio intracelular de Notch

- $\mathrm{ng}=$ nanograma

- $\mathrm{nM}=$ nanomolar

- $\quad$ OP9-GFP = célula estromal de camundongo (controle)

- $\quad$ OP9-DL1 = célula estromal de camundongo com o ligante de Notch (Delta-Like 1)

- $\mathrm{PBS}=$ do inglês "Phosphate Buffered Saline"

- $\quad \mathrm{PCR}=$ do inglês "Polymerase Chain Reaction"

- $\quad \mathrm{PE}=$ do inglês "Phycoeritrin"

- $\quad \mathrm{R} 1$ = Região 1 (representa a população celular delimitada)

- $\quad \mathrm{RBP}-\mathrm{J}=$ recombination recognition sequence binding protein at the JK site

- $\quad \mathrm{RNA}=$ do inglês "Ribonucleic Acid"

- $\mathrm{RPM}=$ rotação por minuto

- $\quad \mathrm{SCU}=$ sangue de cordão umbilical

- $\mathrm{SSC}=$ do inglês "Side Scatter"

- $\quad$ TNF- $\alpha=$ fator de necrose tumoral

- $\mu \mathrm{g}=$ micrograma

- $\mu \mathrm{l}=$ microlitro

- $\mu \mathrm{M}=$ micromolar 


\section{SUMÁRIO}

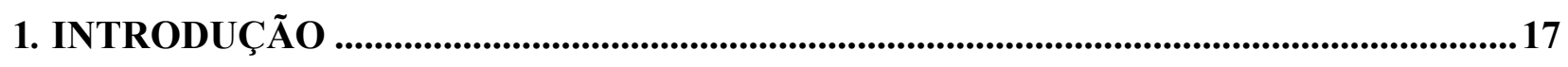

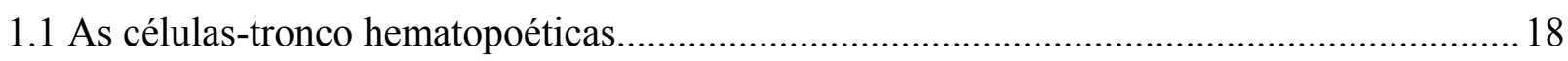

1.2 Origem Embrionária das CTH e Primitividade .............................................................. 19

1.3 Bases Moleculares da Primitividade das CTH: Fatores Intrínsecos e Extrínsecos............... 22

1.4 A Via de Sinalização Notch........................................................................................ 24

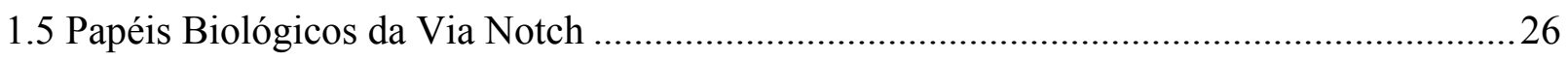

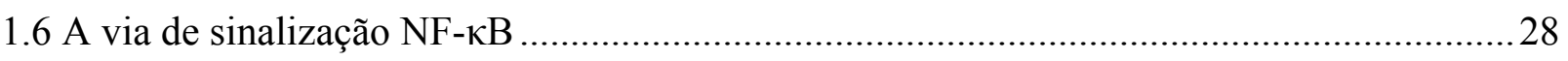

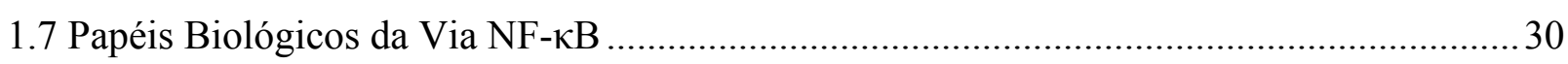

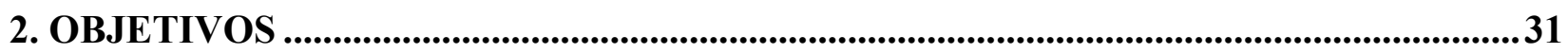

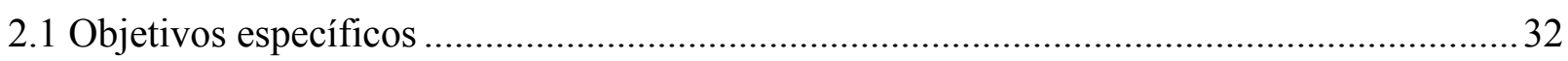

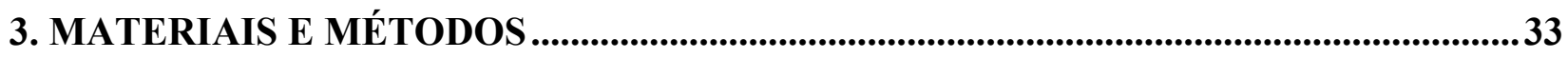

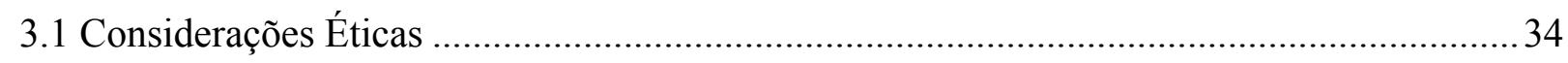

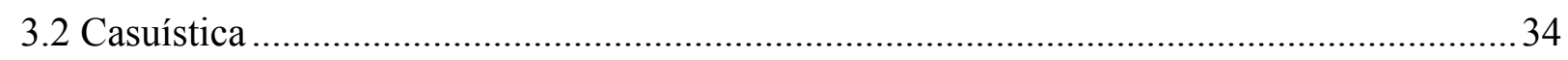

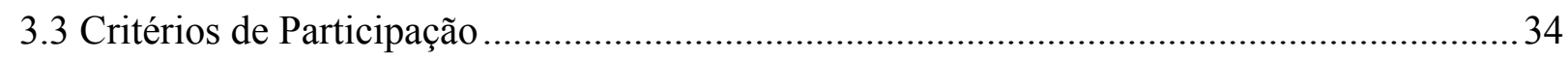

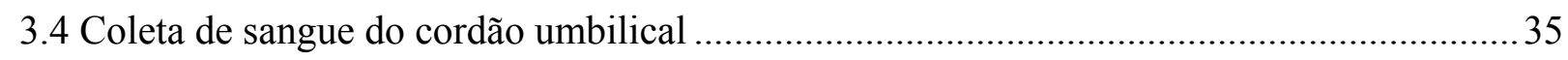

3.5 Isolamento das células mononucleares de Sangue de Cordão Umbilical ............................ 35

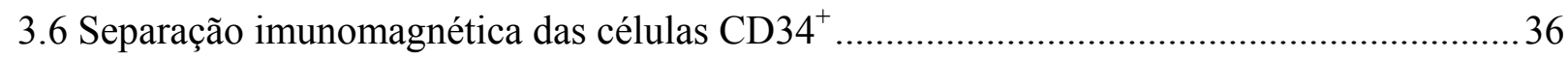

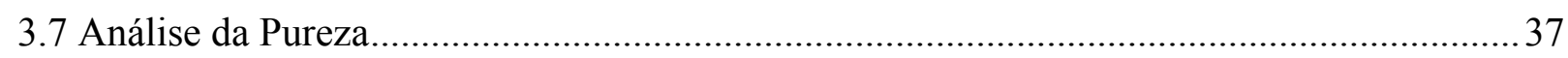

3.8 Ativação da Via Notch nas CTH CD34 ${ }^{+}$pelo Cocultivo com Células OP9 Expressando

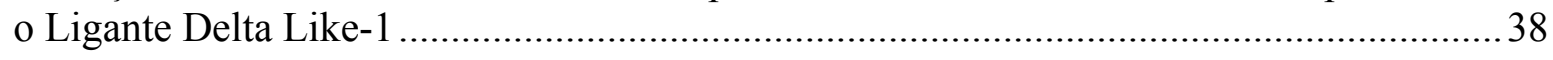

3.9 Avaliação da Diferenciação de Células T por Citometria de Fluxo ................................... 41

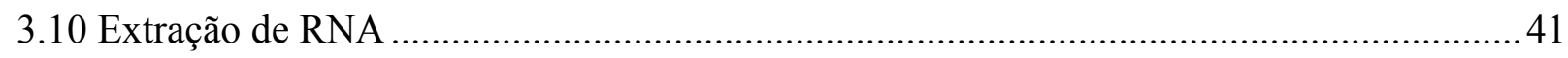

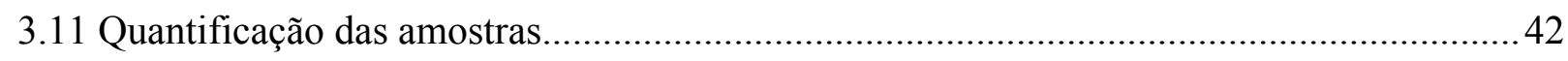

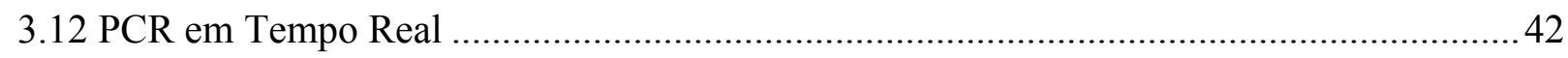

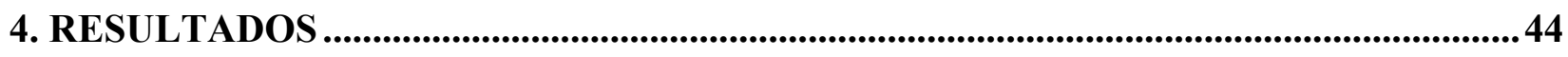

4.1 Expansão e produção de estoque das células estromais de camundongo OP9-GFP e

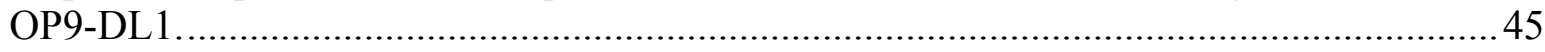

4.2 Análise da pureza das amostras de células-tronco hematopoéticas CD34 ${ }^{+}$isoladas do sangue de cordão umbilical. 
4.3 Determinação da especificidade dos ensaios de PCR em tempo Real na amplificação de transcritos das células-tronco hematopoéticas de humanos em presença de transcritos de células estromais de camundongos.

4.4 Caracterização do sistema de cocultivo das CTH com as células OP9.

4.5 Padronização das concentrações das drogas e do tempo para a avaliação da transcrição dos alvos de interesse.

4.6 Análise da expressão de diferentes transcritos nas $\mathrm{CTH} \mathrm{CD} 34^{+}$durante o cocultivo com

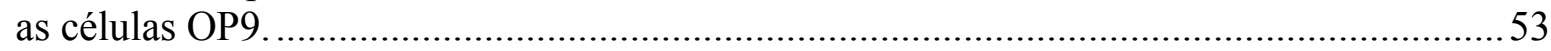

4.6.1 Análise da expressão de HEY1 com 12 horas de cocultivo.........................................54

4.6.2 Análise da expressão de HES1 com 12 horas de cocultivo...........................................58

4.6.3 Análise da expressão de GATA3 com 12 horas de cocultivo.....................................61

4.7 Determinação do tempo de cocultivo para análise de outros transcritos de interesse em sistema de cocultivo das células-tronco hematopoéticas $\mathrm{CD} 34^{+}$com as células OP9. 63

4.7.1 Análise da expressão de HOXB4 com 36 horas de cocultivo......................................64

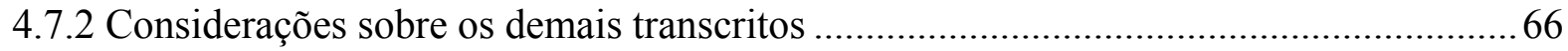

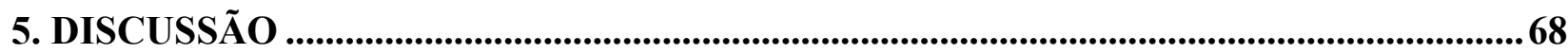

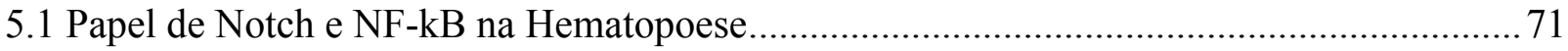

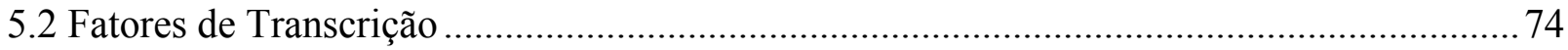

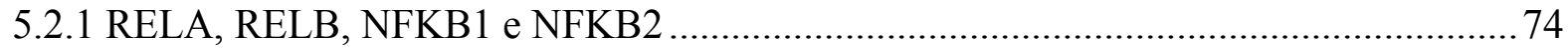

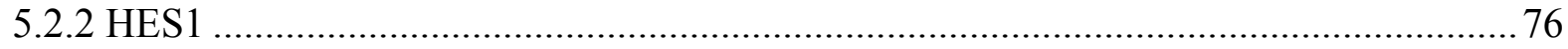

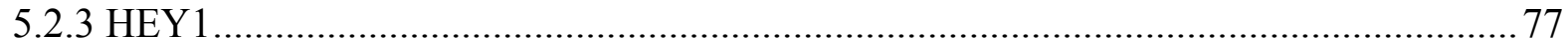

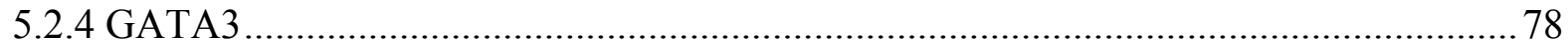

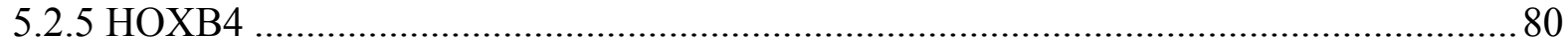

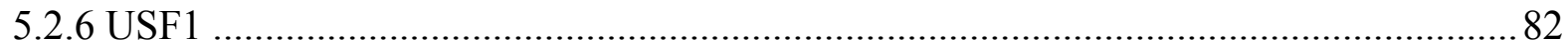

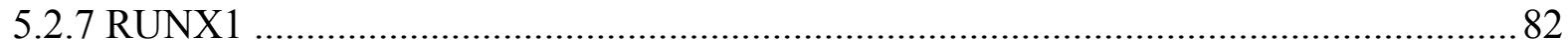

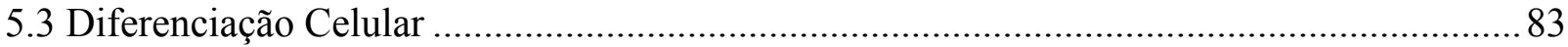

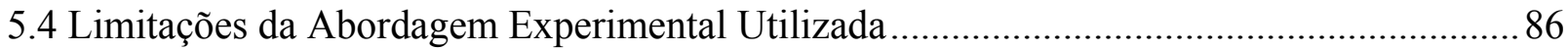

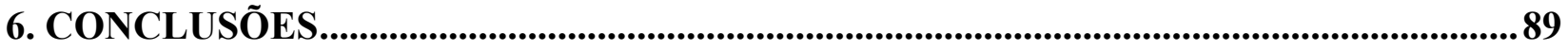

7. REFERÊNCIAS BIBLIOGRÁFICAS ........................................................................92

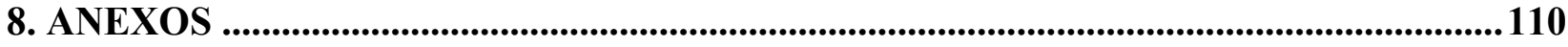


1. INTRODUÇÃO 


\subsection{As células-tronco hematopoéticas}

As células-tronco hematopoéticas $(\mathrm{CTH})$ são um tipo de células-tronco adultas, que possuem a habilidade de originar todas as linhagens hematopoéticas in vivo: a linhagem linfóide, que inclui linfócitos B, T e NK (Natural Killer) e a linhagem mielóide, que inclui eritrócitos, megacariócitos, monócitos e granulócitos (neutrófilos, eosinófilos e basófilos) (Gunsilius et al., 2001; Zago \& Covas, 2006) (Figura 1); sendo as responsáveis, portanto, pela manutenção e proteção do organismo (Ploemacher, 1997; Wognum et al., 2003; Cohen et al., 2004; Gomes et al., 2008).

Assim, essas células apresentam grande potencial para tratamento de desordens hematológicas, imunodeficiências e erros de metabolismo (Petters et al., 2003; Bhattacharya et al., 2005; Kekarainen et al., 2006).

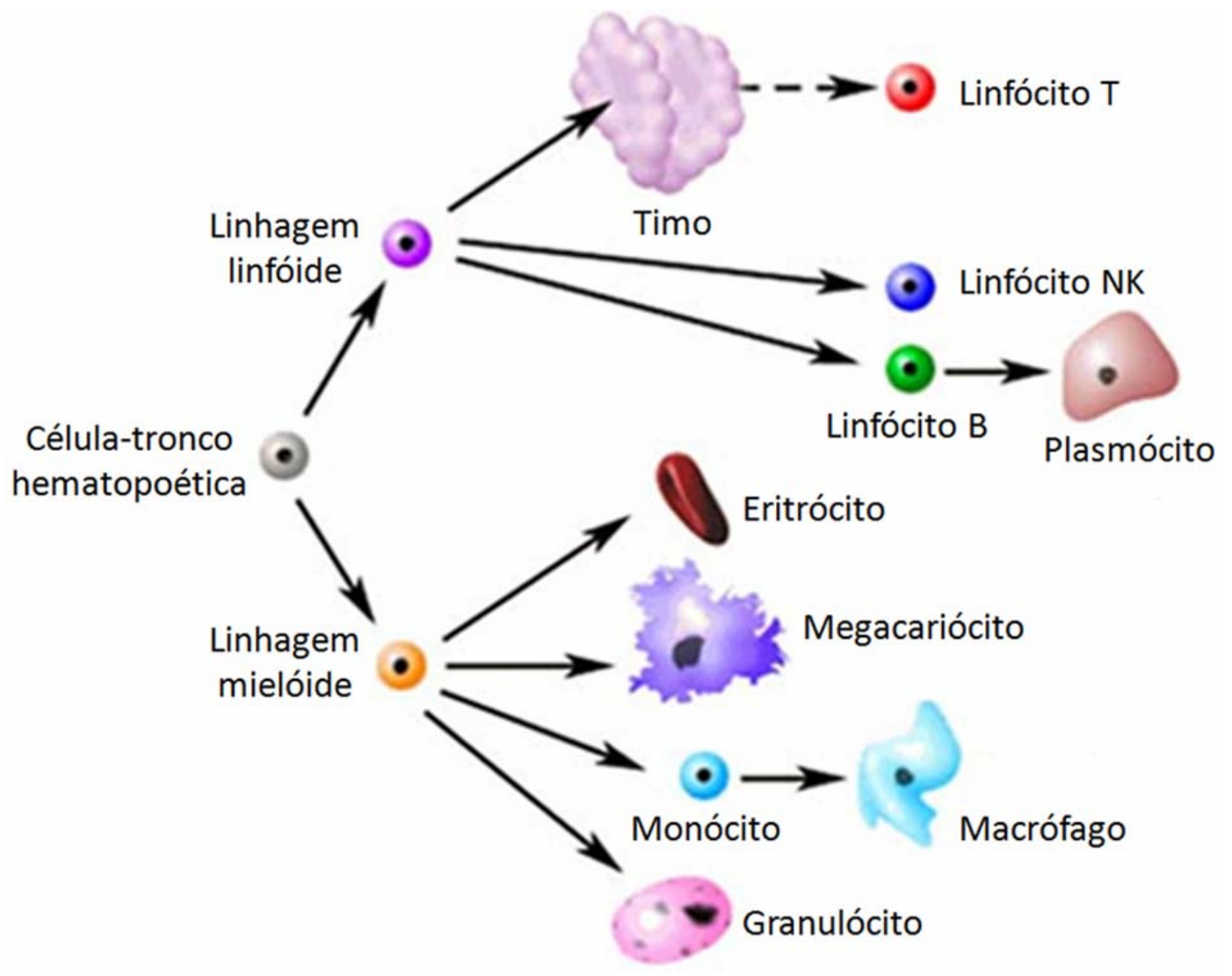

Figura 1. Células-tronco hematopoéticas podem originar duas linhagens celulares, a linhagem mielóide e a linfóide. A primeira origina os eritrócitos, megacariócitos, macrófagos, monócitos e granulócitos enquanto, a linhagem linfóide forma os linfócitos T, B e NK. 
As células-tronco hematopoéticas constituem populações celulares raras, correspondendo, em geral, a apenas de $0,05 \%$ a $0,5 \%$ do total de células de seus reservatórios naturais (medula óssea, sangue de cordão umbilical e sangue periférico) (Gunsilius et al., 2001; Haspel et al., 2008; Frey et al., 2009). Além disso, as CTH consistem em populações heterogêneas e apresentam morfologia bastante similar a dos linfócitos, em função disso, seu isolamento é dificultado, e apenas pode ser realizado com base na caracterização fenotípica das células, através do uso dos marcadores de superfície específicos, denominados por CD (cluster designation ou cluster of differentiation) (Gunsilius et al., 2001).

O principal marcador de superfície característico das células-tronco hematopoéticas é o CD34+ (Baum et al., 1992; Gunsilius et al., 2001; Wognum et al., 2003). Esse marcador é expresso em aproximadamente $1 \sim 4 \%$ das células nucleadas no sangue de medula óssea (MO) humana normal, em apenas $0,1 \sim 0,2 \%$ das células do sangue periférico e, em $0,8 \sim 1,2 \%$ no sangue de cordão umbilical (SCU) (Civin et al., 1990; Gunsilius et al., 2001; Wognum et al., 2003).

O CD34 consiste em uma glicoproteína de membrana com $110 \mathrm{kD}$, e seu domínio Nterminal extracelular possui epítopos que se ligam aos anticorpos usados na identificação das células $\mathrm{CD}^{+} 4^{+}$(Sutherland et al., 1992; Civin et al., 1993). Essa glicoproteína parece apresentar a função de regulação da adesão das células hematopoéticas em células estromais em ambiente hematopoético e, a capacidade de reconstruir a hematopoese humana (Healy et al., 1995). Desta forma, o CD34 tem a capacidade de controlar a localização das células através de interações com outras proteínas de membranas celulares (Sutherland et al., 1992).

\subsection{Origem Embrionária das CTH e Primitividade}

Apesar do marcador CD34 ser largamente utilizado no estudo das $\mathrm{CTH}$, outros marcadores definem populações mais primitivas. É o caso do marcador CD133 que 
caracteriza uma sub-população, as células $\mathrm{CD} 34^{+} \mathrm{CD} 133^{+}$, que demonstram maior capacidade de gerar progenitores em cultura de células por longo período (LTC-IC, long-term cultureinitiating cells) do que as células $\mathrm{CD} 4^{+} \mathrm{CD} 133^{-}$(De Wynter et al., 1996). Acredita-se que este marcador defina uma sub-polpulação dotada de potencial hemato-endotelial, reminiscente da origem embrionária das $\mathrm{CTH}$, a qual ocorreria numa região chamada aorta gônadomesonefros (AGM), a partir do chamado endotélio hemogênico (Dzierzak, 1999).

Após sua emergência, as CTH migram para órgãos como o fígado e o baço, onde a hematopoese ocorrera de forma predominante, durante o período fetal. Ao se aproximar da época do nascimento, as CTH migram novamente pela corrente sanguínea, desses órgãos para a medula óssea (MO) onde se dará a hematopoese no período pós-natal. Por este motivo, ao nascimento, uma grande quantidade de CTH pode ser encontrada no sangue do recém nascido, remanescente na placenta e no sangue de cordão umbilical.

Desta forma, o sangue de cordão umbilical representa uma alternativa para a obtenção de células-tronco hematopoéticas, as quais podem ser utilizadas em transplantes para diversas desordens e doenças (Laughlin et al., 2001). Esse tipo de transplante tem se tornado mais comum desde 1989, devido ao primeiro transplante realizado com sucesso em uma criança com a anemia de Fanconi (Gluckman et al. 1989). Isto porque o sangue de cordão umbilical é coletado logo após o parto e secção do cordão, a coleta não confere riscos nem a mãe nem ao neonato, seu armazenamento e criopreservação são bastante simples, e o risco de transmissão de infecções é reduzido (Rocha et al., 2000). Além disso, o SCU pode ser coletado em todos os partos e armazenados na forma de criopreservados, assim, há rápida acessibilidade desta fonte para transplante, principalmente porque exames de compatibilidade podem ser realizados logo após a coleta, e a exigência deste é menor quando comparada a de transplantes de MO, o que torna o processo mais rápido e eficiente (Sutherland et al., 1992; Wagner et al., 1996; Gluckman et al., 1997; Frey et al., 2009). 
As CTH no recém nascido possuem propriedades mais primitivas que derivam da necessidade do sistema hematopoético em fase de estabelecimento. Nesta fase, as CTH devem possuir um maior potencial de auto-renovação, assim como um potencial maior para a colonização e estabelecimento do sistema linfóide, com a migração das CTH para órgãos linfóides como o timo onde se dará a produção de linfócitos $\mathrm{T}$, um processo particularmente ativo em crianças (Spits et al., 2002).

Como reflexo deste caráter mais primitivo, o uso das células-tronco hematopoéticas do sangue de cordão umbilical em transplantes apresentam algumas vantagens em relação às de medula óssea. Como exemplo, pacientes transplantados com SCU apresentam melhor reconstituição dos progenitores mais primitivos e comprometidos quando comparados com pacientes transplantados com MO, indicando que CTH de SCU privilegiariam auto-renovação ao custo de diferenciação e maturação (Frassoni et al., 2003). Adicionalmente, a função tímica e a diversidade de receptores de células T (TCR) são maiores nos recipientes de SCU do que nos transplantados com MO (Talvensaari et al., 2002). Possivelmente ligado a isto, os receptores de SCU apresentam um menor risco de desenvolver a doença do enxerto contra hospedeiro - DECH (quando linfócitos $\mathrm{T}$ maturos originados a partir da medula óssea transplantada reagem contra o corpo do receptor, levando a uma rejeição severa), uma vez que as $\mathrm{CTH}$ de SCU, pelo seu caráter primitivo, estariam sujeitas aos processos de seleção, comuns nos recém nascidos (Riddell \& Appelbaum, 2007; Frey et al., 2009).

As diferentes propriedades observadas nas CTH de SCU e de MO resultam em parte, de diferenças na composição celular destas fontes (porcentagens distintas de sub-populações mais primitivas). De fato, resultados obtidos por nosso grupo revelaram que enquanto na $\mathrm{MO}$, somente cerca de $35 \%$ das células CD34+ expressam o marcador CD133, no SCU mais de 65\% o fazem (Panepucci et al., 2010). 


\subsection{Bases Moleculares da Primitividade das CTH: Fatores Intrínsecos e Extrínsecos}

Além das diferenças na composição, as CTH também possuem diferenças intrínsecas, que se devem a diferenças de maturidade em sua ontogenia. Estas diferenças intrínsecas se traduzem em mecanismos moleculares ligados a propriedades biológicas fundamentais destas células, como potencial de proliferação, auto-renovação, e diferenciação; que juntas conferem uma maior primitividade.

Estas diferenças, no entanto, refletem uma "programação" que resulta da exposição previa da célula, a fatores extrínsecos presentes em seu local de origem (ou nicho celular); neste nicho, fatores solúveis como citocinas, assim como componentes presentes na membrana de outras células ou na matriz extracelular estabelecem microambientes especializados, que dão suporte, tanto à manutenção do pool de células-tronco indiferenciadas, como à diferenciação em linhagens específicas (Schmitt et al., 2006; Mitsiadis et al., 2007).

As diferentes propriedades intrínsecas de $\mathrm{CTH}$ obtidas de fontes diferentes (SCU ou $\mathrm{MO})$, ou de diferentes sub-populações $\left(\mathrm{CD}^{+} 4^{+}\right.$ou $\left.\mathrm{CD} 133^{+}\right)$são um reflexo direto do programa genético atuante nestas células, o qual pode ser inferido por seus perfis transcricionais. Neste sentido, Panepucci e colaboradores (2010), comparando os perfis de expressão gênica de $\mathrm{CTH} \mathrm{CD} 34^{+}$com sub-populações mais primitivas enriquecidas de $\mathrm{CTH}$ $\mathrm{CD} 133^{+}$(de Wynter et al., 1998), verificaram que as células mais primitivas apresentam níveis de expressão mais altos de diversos fatores de transcrição (FT) envolvidos com os processos iniciais da emergência das $\mathrm{CTH}$ a partir do endotélio hemogênico, bem como, com os processos iniciais de comprometimento e diferenciação das CTH em linfócito T no timo; entre eles: RUNX1/AML1 (Hirai et al., 2005; Tsuzuki et al., 2007), GATA3 (Ho et al., 2007), USF1 (Giannola et al., 2000; Zhu et al., 2003), TAL1/SCL (Jaffredo et al., 2005; Reynaud et al., 2005; Kurita et al., 2006; Patterson et al., 2007), HOXA9 (Wagner et al., 
2004; Dorsam et al., 2004; Ferrell et al., 2005) e HOXB4 (Buske et al., 2002; Kyba et al., 2002; Dai et al., 2006).

Análises complementares dos promotores dos FT mais expressos nas $\mathrm{CTH}$ CD133 ${ }^{+}$

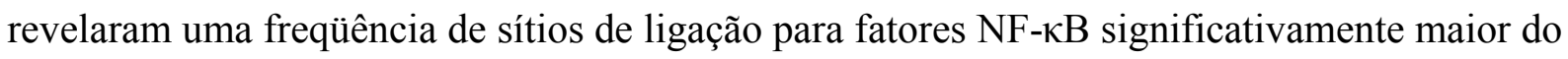
que a esperada, e presentes em potenciais alvos transcricionais como RUNX1, GATA3 e USF1. Além disso, verificaram que a maioria dos transcritos apresenta níveis de expressão significativamente maior nas células $\mathrm{CD}_{133^{+}}$de $\mathrm{MO}$, comparados com as células $\mathrm{CD} 34^{+}$de $\mathrm{MO}$, e que as células de $\mathrm{SCU}$, por sua vez, apresentam níveis significativamente mais elevados de NOTCH1, NF-кB2, RELB, RUNX1, TAL1 e HOXB4 do que as células de MO, para ambas as populações (CD34 e CD133). Finalmente, análises estatísticas utilizando estas quantificações permitiram a identificação de correlações positivas significantes entre todos os transcritos avaliados, sugerindo a existência de uma rede transcricional altamente

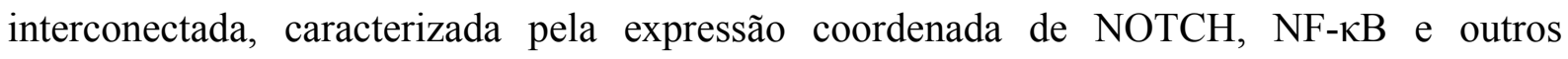
importantes FT, que atuariam na manutenção de um estado mais primitivo das $\mathrm{CTH}$, incluindo uma maior capacidade de auto-renovação e um maior potencial de diferenciação linfóide (Panepucci et al., 2007; Panepucci et al., 2010).

Os sinais providos pelo microambiente hematopoético resultam na ativação de diversas vias de sinalização, envolvidas com a biologia das CTH neste nicho (Blank et al., 2008). Entre outras, a via Notch tem papel de destaque por ser indispensável para o surgimento das células-tronco hematopoéticas durante o desenvolvimento embrionário, e pelo papel na diferenciação das CTH em linfócitos T (Bigas et al., 2010).

O papel da via de sinalização NF-אB nas células-tronco hematopoéticas ainda é pouco compreendido e teria papel na sobrevivência das CTH CD34+, uma vez que sua inibição correlaciona-se com a inibição da formação de colônias em ensaios clonogênicos (Pyatt et al., 
1999), provavelmente, prevenindo a apoptose em múltiplos níveis, através da eliminação de espécies reativas de oxigênio (Nakata et al., 2004).

Interessantemente, a interação (ou "cross-talk") entre as vias Notch e NF-kB tem sido relatada pela literatura recente. Espinosa e colaboradores (2002) afirmam que a interação direta de Notch-IC e p50-NFKB leva a inibição da atividade transcricional de NF- $\kappa$ B. Assim como, Guan e colaboradores (1996) os quais afirmam que a ativação de Notch promove a

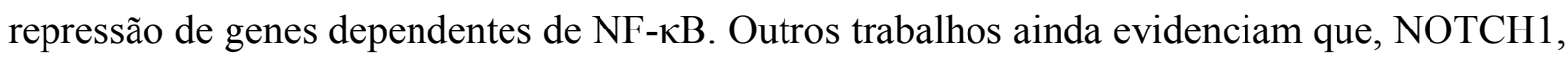
principal indutor do comprometimento de CTH para a diferenciação em células T (de Smedt

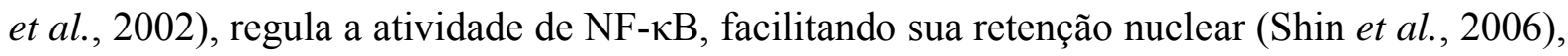
aumentando os níveis dos transcritos de suas diferentes subunidades (Cheng et al., 2001), e proporcionando a de-repressão do gene NF-кB2 (Nakazawa et al., 2001; Oswald et al., 1998). Dados recentes indicam a colaboração entre as vias NF- $\kappa$ B e Notch em processos normais e patológicos (Wang et al., 2006a; Wang et al., 2006b; Ramdass et al., 2007).

Como a interação entre as vias NF-אB e Notch na regulação de transcritos permanece pouco estudada, neste trabalho, investigamos o papel desempenhado por essas vias, na regulação transcricional de genes de fatores de transcrição selecionados, em células troncohematopoéticas, durante o período inicial da ativação da via Notch.

A seguir as vias Notch e NF-kB são detalhadas, com o objetivo de embasar o desenho experimental proposto neste trabalho.

\subsection{A Via de Sinalização Notch}

Notch é um receptor transmembrana celular, do tipo heterodimérico, conservado evolutivamente, é expresso em células-tronco hematopoéticas, células progenitoras e em células estromais (Chadwick et al., 2006; Curry et al. 2006; Ang et al., 2007; Beck et al., 2009; Borggrefe et al., 2009). 
Em mamíferos existem quatro tipos de receptores Notch: Notch 1, Notch2, Notch3 e Notch4 (Schmitt et al., 2002), e cinco ligantes transmembranas, sendo esses constituintes de duas famílias distintas, os conhecidos por Delta-like (Delta-like 1, Delta-like3 e Delta-like4) e os ligantes Jagged (Jagged1 e Jagged2) (Artavanis-Tsakonas et al., 1999; Radtke et al., 2004; Rao et al., 2009). A participação de receptores, ligantes e moduladores de Notch na regulação da linhagem T durante o desenvolvimento linfocitário já é descrito pela literatura e, o receptor que mais se destaca nessa função é o Notch 1 (Radtke et al., 2004; Wang et al., 2006b; Gravano et al., 2010).

A via Notch é ativada através do contato célula a célula, ou seja, é iniciada pela interação do receptor e ligante Notch, seguido por dois processos de clivagens proteolíticas, o primeiro é ocasionado por metaloproteases da família ADAM e, o segundo, pela $\gamma$-secretase, um complexo enzimático que contém presenilina, nicastrina, Pen2 e APH1 (Chadwick et al., 2006; Borggrefe et al., 2009). O segundo processo libera o domínio intracelular do Notch (NICD), que é translocado da membrana para o núcleo e atua como coativador transcricional (Lahmar et al., 2008). O Notch ativo (NICD) interage com o fator transcricional ubiquitinoso (RBPJk/CSL) para regular positivamente a transcrição dos genes alvos, como HEY1 e HES1 (Figura 2) (Espinosa et al., 2002; Lehar \& Bevan, 2002; Radtke et al., 2004; Lee et al., 2009; Magri et al., 2009).

Essa via de sinalização pode ser bloqueada através do uso de drogas farmacológicas como, por exemplo, a DAPT (N-[N-(3,5-Difluorophenacetyl-L-alanyl)]-S-phenylglycine tButyl Ester) (Calbiochem $\left.{ }^{\circledR}\right)$, a qual atua no complexo $\gamma$-secretase, impedindo sua atuação (Zúñiga-Pflücker, 2004; Dontje et al., 2006; Farnie et al., 2007; O’Neil et al., 2007; Chadwick et al., 2009). 


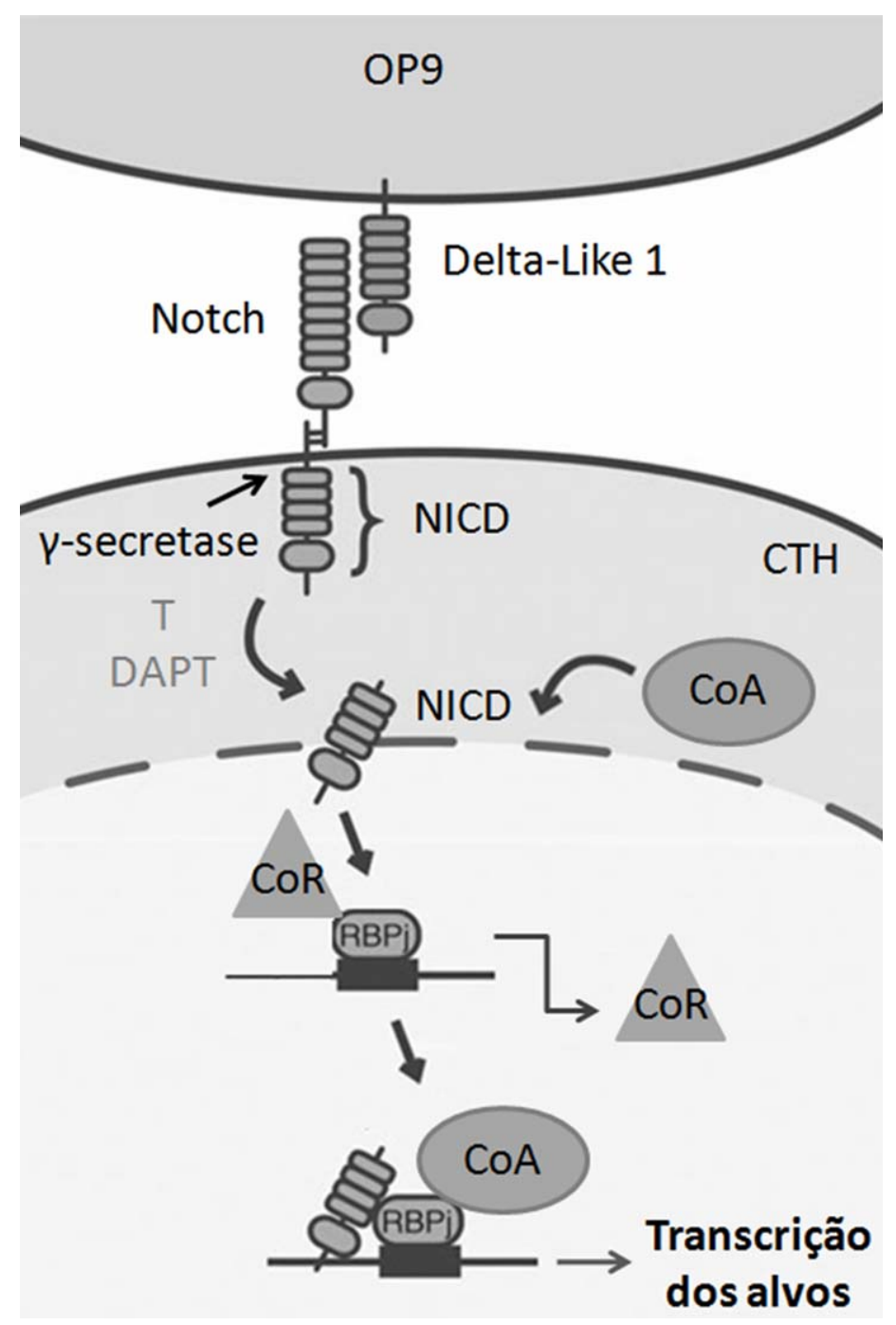

Figura 2. Esquema da sinalização da via Notch. Mediante a interação com o ligante, o receptor de Notch é clivado pelo complexo $\gamma$-secretase, resultando na liberação do domínio intracelular (NICD) que é transportado ao núcleo da célula. Esse se liga a um complexo de proteínas contendo a proteína ligante de DNA RBP-J/CSL e, após liberação de correpressores (CoR) e recrutamento de coativadores (CoA), inicia-se a transcrição de genes alvos (como HEY1 e HES1). O local de atuação da droga DAPT, que inibe a liberação do NICD através da inibição da clivagem mediada pela $\gamma$-secretase, também é evidenciado no esquema.

\subsection{Papéis Biológicos da Via Notch}

A via de sinalização Notch apresenta relação com diversos processos como, por exemplo, o de diferenciação, proliferação e apoptose durante o desenvolvimento embrionário e, com a homeostase durante a vida pós-natal, principalmente na diferenciação de progenitores hematopoéticos e no desenvolvimento de células T (Artavanis-Tsakonas et al., 1999; Singh et al., 2000; Jaleco et al., 2001; Walker et al., 2001; Schmitt et al., 2002; Iso et al., 2003; Radtke et al., 2004; Wilson et al., 2006; Kutlesa et al., 2009; Lee et al., 2009; Magri et al., 2009). 
A maioria das linhagens hematopoéticas sofre o processo de diferenciação dentro da medula óssea, no entanto, esse ambiente não é capaz de suportar a linfopoese $\mathrm{T}$, assim, os progenitores das células T migram para o timo, o único órgão que possui condições essenciais para o desenvolvimento dessas células como, por exemplo, a via de sinalização Notch, considerada crítica para o comprometimento das células e indução da linfopoiese T (Hare et al., 1999; Deftos et al. 2000; Schmitt et al., 2002; Rothenberg et al., 2005; Schmitt et al., 2006; Plum et al., 2008; Gravano et al., 2010).

A linfopoese $\mathrm{T}$ pode ter o seu processo acompanhado através dos diferentes marcadores de superfície que passam a ser expressos pelas células ao longo da diferenciação (Dudley et al., 2009). Inicialmente as $\mathrm{CTH} \mathrm{CD} 4^{+} \mathrm{CD}^{-} \mathrm{CD} 1 \mathrm{a}^{-\mathrm{CD}} 4^{-} \mathrm{CD} 8^{-}$passam a expressar $\mathrm{CD} 7^{+}$, em seguida $\mathrm{CD} \mathrm{a}^{+}$e por fim, $\mathrm{CD} 4^{+} \mathrm{CD} 8^{+}$, tornando-se células duplo positivas. Essas ainda passam posteriormente a expressar o marcador CD3. Ao final do processo de diferenciação as células tornam-se simples positivo, sendo algumas células apenas $\mathrm{CD}^{+} \mathrm{CD} 3^{+}$, enquanto outras são apenas $\mathrm{CD}^{+} \mathrm{CD}^{+}$(Spits et al., 2002; Blom et al., 2006) (Figura 3).

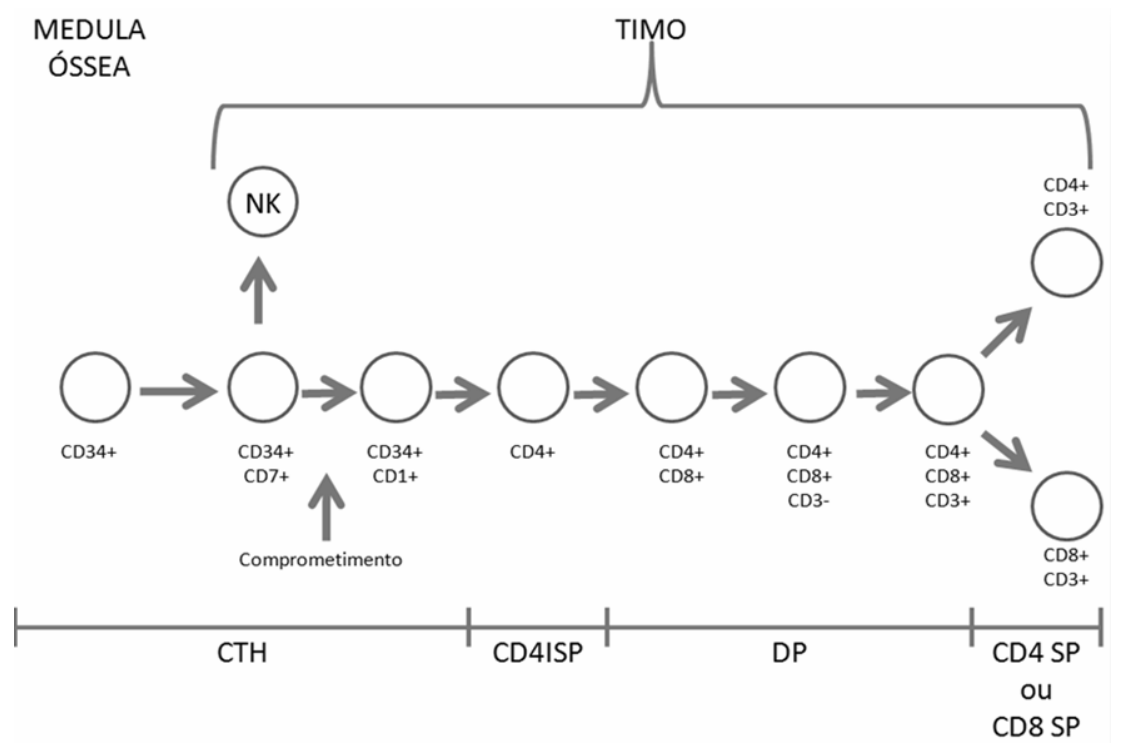

Figura 3. Esquema ilustrativo do processo de diferenciação celular a partir das células-tronco hematopoéticas $\mathrm{CD} 4^{+}$ao longo da linfopoiese, destacando os principais marcadores de superfícies específicos de cada estágio da diferenciação. Inicialmente, há o aparecimento dos marcadores CD7 e CD1a, em seguida do $\mathrm{CD} 4$ e CD8, até a formação das células linfocíticas $\mathrm{T} \mathrm{CD}^{+} \mathrm{CD}^{+}$e $\mathrm{CD}^{+} \mathrm{CD}^{+}$simples positivas. 


\subsection{A via de sinalização NF-кB}

O NF-kB (Nuclear Factor kappa B) é um fator transcricional eucariótico, composto por complexos de homo e heterodímeros de polipeptídios da família Rel (Beinke et al., 2004). Em mamíferos, o NF-кB consiste em cinco proteínas relacionadas: Rel A (p65), Rel B, c-Rel,

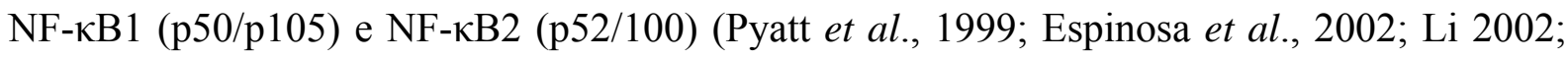
Beinke et al., 2004; Moynagh, 2005; Hoffman et al., 2006). Essas proteínas podem ser reunidas em dois grupos: um deles com as p100 e p105 que apresentam um domínio Cterminal com múltiplas cópias de anquirinas as quais reprimem a atividade da molécula e, portanto, permanecem como precursores inativos até que sejam alvo de proteólise, assim p105 é transformada em p50 e a p100 em p52 (Yamamoto, 2001; Espinosa et al., 2002; Suh et al., 2004). E o segundo grupo engloba as proteínas RelA, RelB e c-Rel que possuem maior número de domínios na região $\mathrm{C}$ terminal e apresentam-se em sua forma ativa (Yamamoto,

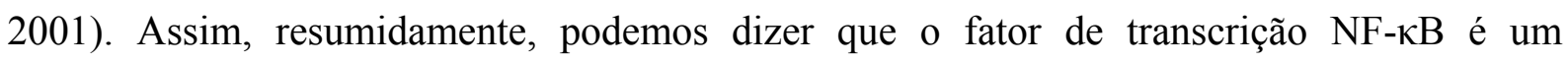

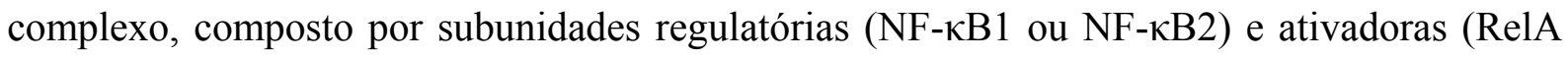
ou RelB), que permanece no citoplasma quando inativo.

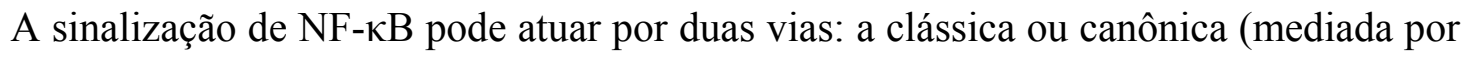

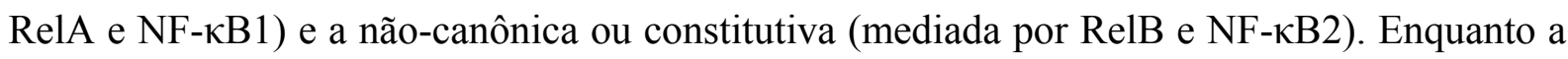
última é responsável pela ativação continuada de $\mathrm{NF}-\kappa \mathrm{B}$, a primeira pode influenciar sua duração e amplitude (Beinke et al., 2004).

A via canônica é mediada pela ativação do complexo das quinases IאB (IKK inibidor da ligação do complexo NF-אB), o qual medeia a fosforilação de resíduos específicos das moléculas I $\mathrm{KB}$ em resposta a estímulos como, por exemplo, o de TNF- $\alpha$, e por posterior processo de ubiquitinação e degradação de $\mathrm{I} \kappa \mathrm{B}$, que permite a ligação do DNA e acúmulo de

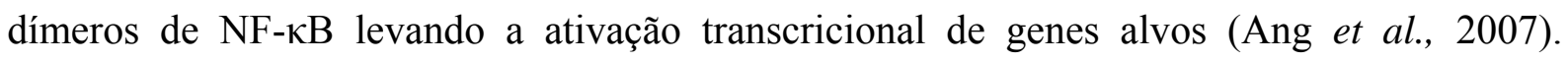
Enquanto, que a ativação da via não canônica é mediada por alguns estímulos como a 
linfotoxina $\beta$ que dependem do precursor p100 (Figura 4) (Chen et al., 2001; Beinke et al., 2004; Wang et al., 2006b; Ang et al., 2007). Assim, com a ligação de certos fatores agonistas (como IL1A, IL1B, TNF- $\alpha$, LTB ou TGFB1) a receptores (como TNFRSF1B ou TNFRSF4), proteínas citoplasmáticas promovem a translocação do complexo para o núcleo, ativando a transcrição de genes alvos (tais como CXCL2, CXCL3, ICAM1, IL8, CCL4L, IL1B, NF-אB2, RELB e LTB e outros).

Essa via de sinalização pode ser bloqueada atrás do uso de inibidores farmacológicos, como por exemplo, o BAY-117082 (\{(E)3-[(4-Methylphenyl)sulfonyl]-2-propenenitrile $\})$ (Calbiochem $\left.{ }^{\circledR}\right)$, que possui habilidade de impedir a fosforilação de IкB e, consequentemente,

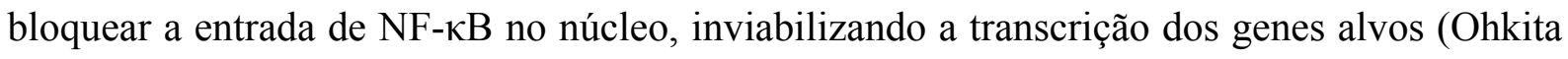
et al., 2002; Giraldo et al., 2009).

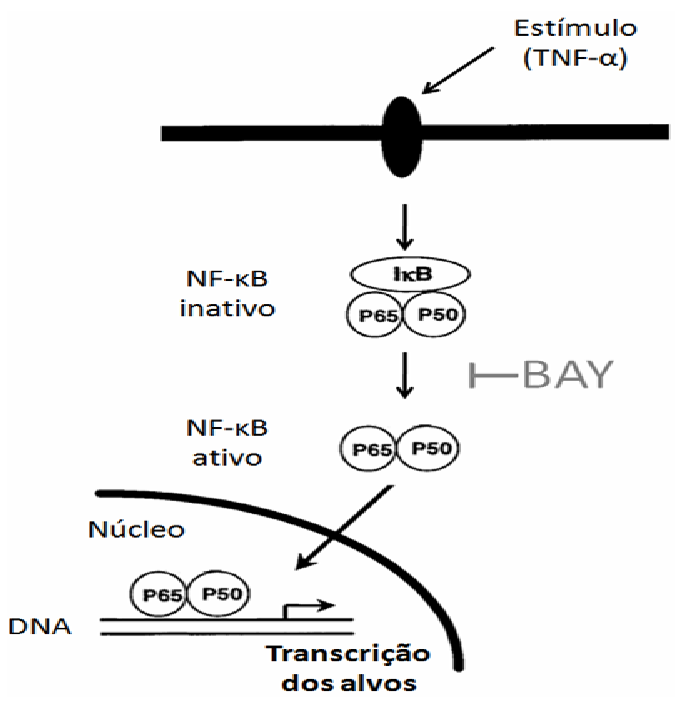

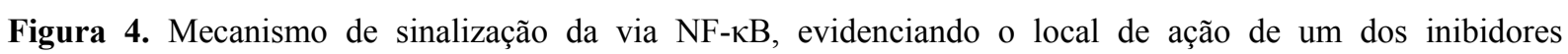
farmacológicos desta via, o BAY (que impede a fosforilação, e consequentemente inibe a transcrição dos alvos dessa via). 


\subsection{Papéis Biológicos da Via NF-кB}

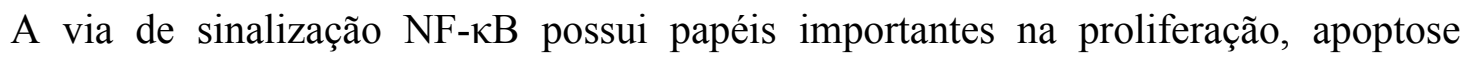
celular e na biologia de células do sistema imune (Ghosh et al., 1998; Pyatt et al., 1999; Espinosa et al., 2002; Li et al., 2002; Beinke et al., 2004; Bonizzi et al., 2004; Dejardin, 2006), bem como na ativação das células T, maturação das células B e transcrição do vírus da imunodeficiência humana (Pyatt et al., 1999). Além disso, é requerido para a expressão de diversos produtos gênicos relevantes a hematopoese, incluindo a interlecina $1 \beta$ (IL-1 $\beta$ ), fator de necrose tumoral (TNF- $\alpha$ ), IL-6, fator estimulante de colônia de macrófago (M-CSF), fator estimulante de colônia de macrófago e granulócitos (GM-CSF), eritropoiese (EPO) e interferon- $\gamma(\mathrm{INF}-\gamma)($ Pyatt et al., 1999). 
2. OBJETIVOS 
Avaliar a dependência da via Notch, bem como o papel de TNF- $\alpha$ em sua modulação, na expressão de potenciais alvos transcricionais, no período inicial do processo de comprometimento de $\mathrm{CTH} \mathrm{CD} 34^{+}$com a linhagem $\mathrm{T}$ linfocítica,

\subsection{Objetivos específicos}

- Isolar as células-tronco hematopoéticas CD $34^{+}$do sangue de cordão umbilical.

- $\quad$ Realizar ensaios in vitro de diferenciação de linfócitos T, a partir de CTH CD34 purificadas imunomagneticamente de amostras de SCU cocultivadas com células estromais de camundongo e avaliar o processo por citometria de fluxo.

- Avaliar a influência do TNF- $\alpha$ no processo de diferenciação de linfócitos T in vitro, a partir de $\mathrm{CTH} \mathrm{CD} 34^{+}$purificadas imunomagneticamente de amostras de SCU cocultivadas com células estromais de camundongo e avaliar o processo por citometria de fluxo.

- $\quad$ Avaliar diferentes transcritos nas $\mathrm{CTH}$ CD34 ${ }^{+}$cocultivadas (HEY1, HES1, GATA3,

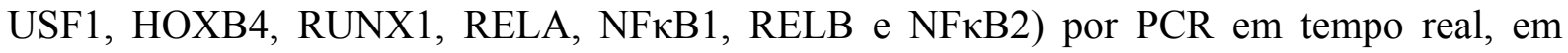
diferentes tempos de cocultura.

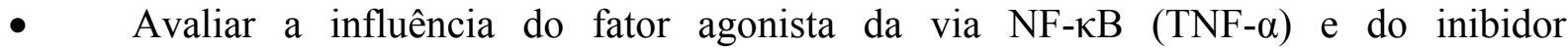
farmacológico (BAY11-7082); do inibidor da via Notch (DAPT), além da influência da droga cycloheximide (CHX) na regulação de diferentes transcritos (HEY1, HES1, GATA3, USF1,

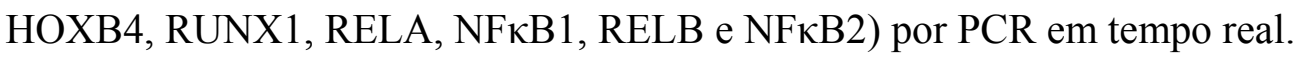


3. MATERIAIS E MÉTODOS 


\subsection{Considerações Éticas}

As amostras de células $\mathrm{CD}^{+} 4^{+}$de sangue de cordão umbilical foram obtidas com consentimento dos responsáveis de acordo com projeto aprovado pela Comissão de Ética em Pesquisa do Hospital das Clinicas da USP (n 1405/2009) de Ribeirão Preto (anexo 1) e pela Comissão de Pesquisa da Mater (Centro de Referencia para a Saúde da Mulher). O termo de consentimento livre e esclarecido (anexo 2) foi apresentado aos responsáveis pela enfermeira Maria Fernanda Lopes, contratada da Mater, responsável pela coleta de sangue de cordão umbilical.

\subsection{Casuística}

O número de amostras necessárias para o desenvolvimento deste projeto foi de 20 amostras, sendo quatro (4) para experimentos de padronização, quatro (4) para experimento de diferenciação e doze (12) para réplicas biológicas dos demais experimentos.

\subsection{Critérios de Participação}

Foram candidatas potenciais à doação de sangue de cordão umbilical e placentário as parturientes e seus filhos (independente de raça, classe social ou religião) atendidos no centro obstétrico (durante os anos de 2009 a 2010), entre as 7 horas de segunda até as 10 horas de sexta-feira com idade gestacional acima de 35 semanas; peso fetal maior que $2800 \mathrm{~g}$; bolsa rota há menos de 12 horas.

Critérios de exclusão:

Não consentimento da mãe para a coleta mediante esclarecimento da pesquisa ou gestantes que tenham:

apresentado complicações infecciosas durante a gestação ou que tenham patologia que comprometa a vitalidade da placenta.

$>$ risco aumentado para a transmissão de doenças virais ou sexualmente transmissíveis (usuárias de drogas injetáveis, comportamento sexual com risco acrescido).

doença congênita (talassemia, doença falciforme, plaquetopatias, etc.).

reação sorológica positiva para as doenças ou agentes infecciosos (Sífilis, Doença de Chagas, Hepatite B, Hepatite C, HTLV 1 e 2, HIV 1/ 2, Toxoplasmose, Citomegalovírus). 


\subsection{Coleta de sangue do cordão umbilical}

O SCU foi coletado pela equipe de obstetrícia do hospital da MATER de Ribeirão Preto, para tal fim utilizou-se técnicas de assepsia logo após o parto e secção do cordão umbilical. A punção da veia do cordão umbilical foi efetuada com agulha acoplada a uma bolsa de coleta (JP indústria farmacêutica, Ribeirão Preto, SP, Brasil), contendo $25 \mathrm{ml}$ de solução anticoagulante CPD (citrate phosphate dextrose). $\mathrm{O}$ material foi mantido a $4^{\circ} \mathrm{C}$ e processado num período de 12 horas.

\subsection{Isolamento das células mononucleares de Sangue de Cordão Umbilical}

As células mononucleares (CMN) foram isoladas por centrifugação em gradiente de densidade utilizando Ficoll-Hypaque PLUS (Amersham Biosciences, No.17-1440-02), para esse procedimento realizou-se uma pré-centrifugação a $1200 \mathrm{rpm}$ por 10 minutos a fim de retirar parte das plaquetas existentes no plasma do sangue de cordão umbilical. Posteriormente, adicionou-se PBS (tampão fosfato salina) com $0,6 \%$ ACD (acid citrate dextrose) ao sangue, na proporção de 1:3, após homogeneização foi adicionado lentamente 13 $\mathrm{ml}$ de Ficoll na parte inferior de cada tubo (falcon $50 \mathrm{ml}$ ), resultando na formação de duas fases, a orgânica (mais inferior, composta por solução de Ficoll) e a aquosa (mais superior composta pela amostra diluída). Em seguida, as amostras passaram por centrifugação de 2000 rpm por 30 minutos à temperatura ambiente, resultando na formação de um anel entre as fases, onde se localizam as CMNs. Essas foram recolhidas e transferidas para outros tubos, que passaram por processo duplo de lavagem com PBS $1 \mathrm{X}$ com $\mathrm{ACD}(0,6 \%)$ e centrifugação de $1500 \mathrm{rpm}$ por 10 minutos. Devido à grande concentração de eritroblastos presentes no SCU, as amostras foram submetidas ao processo de lise de hemácias, utilizando a solução de lise ACK (Cloreto de Amônio), mantidas em gelo por 10 minutos. Posteriormente, $30 \mathrm{ml}$ de PBS 1X com albumina humana foram adicionados e as amostras, em seguida, foram 
centrifugadas a $1500 \mathrm{rpm}$ por 10 minutos, a lavagem foi repetida, o pellet formado foi ressuspenso em tampão de coluna (PBS 1X, 0,6\% ACD e 0,5\% albumina) e as células foram contadas em câmara de Neubauer (Figura 5).

\subsection{Separação imunomagnética das células $\mathrm{CD34}^{+}$}

As células $\mathrm{CD}^{+} 4^{+}$(contidas entre as mononucleares) foram isoladas imunomagneticamente a partir das amostras utilizando o Kit MACS Direct CD34 Progenitor Cell Isolation Kit (No.130-046-702, Miltenyi Biotec), seguindo as instruções do fabricante, sob condições assépticas. Para isso, as células mononucleares foram incubadas com anticorpos monoclonais anti-CD34 (clone QBEND/10) ligados a partículas magnéticas (beads) por 30 minutos a $4^{\circ} \mathrm{C}$. As amostras foram passadas através da coluna de separação magnética sob campo magnético e, assim, as células $\mathrm{CD} 34^{+}$marcadas magneticamente ficaram retidas na coluna LS (Miltenyi Biotec, No. 130-042-201) por meio de um imã SuperMACS (Miltenyi Biotec, No. 130-044-104). A coluna, ainda na presença do imã, foi lavada com tampão de coluna, a fim de retirar as demais células. Posteriormente, a coluna foi retirada do campo magnético, realizou-se a eluição e contagem das células CD34+ (Figura 5).

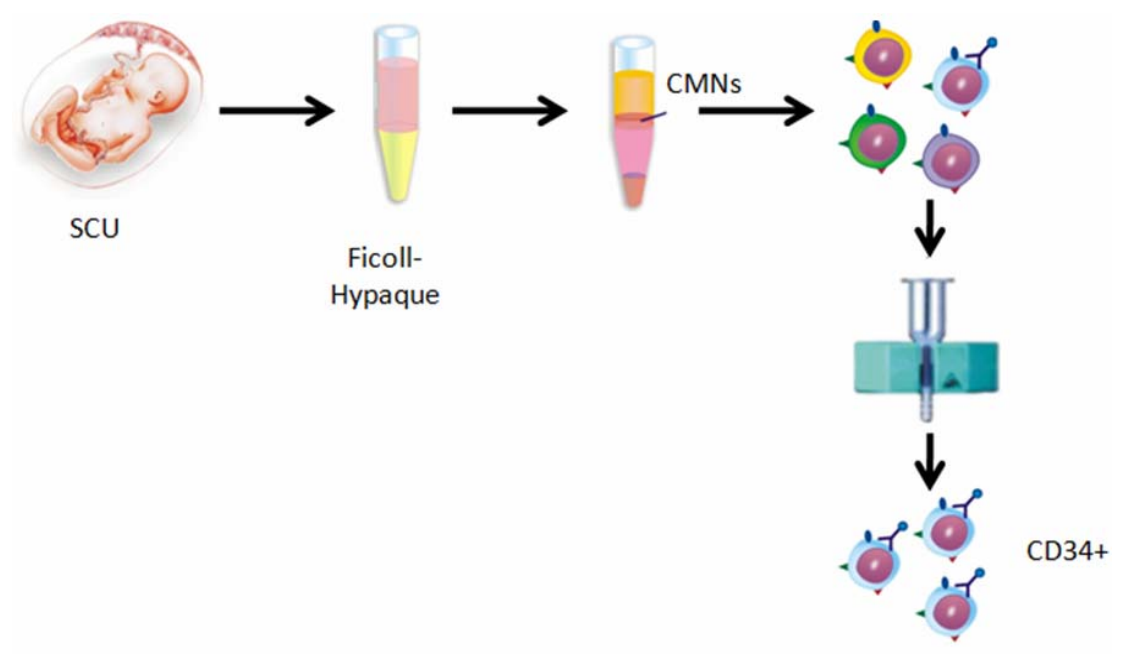

Figura 5. Esquema ilustrativo do isolamento imunomagnético das células-tronco hematopoéticas $\mathrm{CD} 34^{+}$a partir do sangue de cordão umbilical (SCU), destacando as principais etapas durante esse procedimento (separação por densidade de gradiente com Ficoll-Hypaque; isolamento das células mononucleares ; e separação imunomagnética das $\mathrm{CTH} \mathrm{CD} 34^{+}$). 


\subsection{Análise da Pureza}

Após a separação imunomagnética, cerca de $2{ }_{x} 10^{5}$ células foram reservadas para análise da pureza e caracterização da composição da amostra em citometria de fluxo. Para isso, a porção de células reservadas para a citometria, que foi separada imunomagneticamente, foram ressuspensas em $200 \mu \mathrm{l}$ de PBS 1X, e divididas em duas alíquotas de $100 \mu 1$. A uma delas adicionou-se $3 \mu 1$ do anticorpo anti-CD34 conjugado ao PerCP (Peridinin-chlorophyllprotein complex) e ao outro tubo (controle) foi adicionado $3 \mu 1$ do anticorpo inespecífico ỵ 1 conjugado com PerCP (Becton Dickinson, san Jose, CA, EUA). Os tubos foram incubados por 20 minutos no escuro, adicionou-se, em seguida, $2 \mathrm{ml}$ de PBS 1x e centrifugou-se a 1800 rpm por 5 minutos. O sobrenadante foi descartado e o pellet foi ressuspenso em $200 \mu 1$ PBS 1X Formol, após isso a análise foi realizada em citômetro FACSCalibur (Becton Dickinson, San Jose, Ca, EUA) utilizando o software específico CellQuest (Becton Dickinson, San Jose, CA, EUA). Neste, cerca de 10.000 a 50.000 eventos foram adquiridos e plotados em função dos parâmetros de FSC (forward scatter - tamanho celular) e SSC (side scatter granularidade celular), de acordo com esses parâmetros os eventos foram selecionados através de gates, isolando e calculando a porcentagem das células de acordo com as marcações por anticorpo (Figura 6).
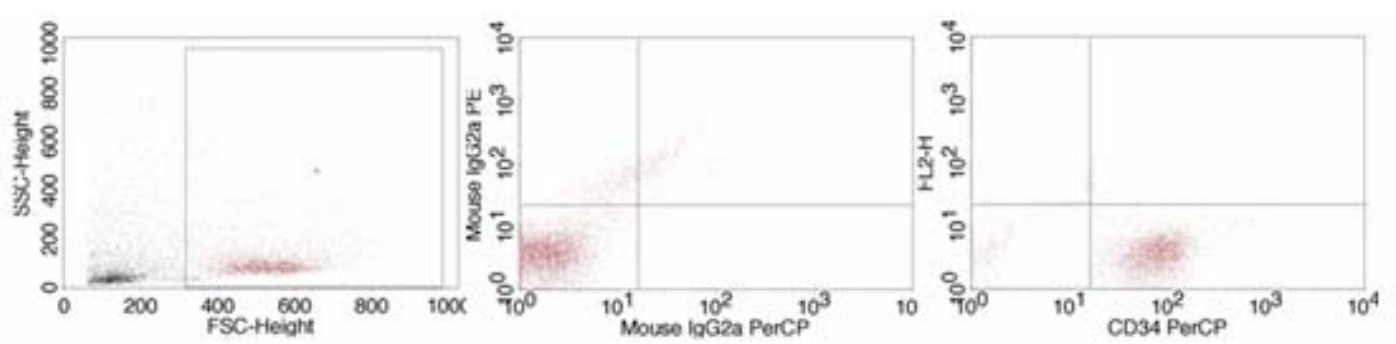

Figura 6. Estratégia adotada para a determinação da expressão do marcador CD34 em citometria de fluxo. Durante a aquisição das células, foi desenhada uma gate na população de progenitores linfocitários (R1), estabelecida com base nos parâmetros de tamanho (FSC) por granularidade (SSC) (A). Os dot plots revelam a marcação dos eventos selecionados por R1, para os isotipos controles $\operatorname{IgG} 1 / \operatorname{IgG} 2 \mathrm{a}$ (B) e para o sinal de CD34-PerCP (C). 


\subsection{Ativação da Via Notch nas CTH CD34 $^{+}$pelo Cocultivo com Células OP9 Expressando o Ligante Delta Like-1}

Com o objetivo de avaliar o efeito da ativação da via Notch na transcrição de fatores transcricionais selecionados, utilizamos o sistema OP9-DL1, composto por células OP9 expressando o ligante de Notch, Delta-like 1 (De Smedt et al., 2004; La Motte-Mohs et al., 2005; Schmitt \& Zuniga-Pflucker, 2002).

A linhagem OP9 consiste em células estromais da medula óssea de camundongo, deficientes para o fator de estimulação de colônia de macrófagos (M-CSF - macrophage colony-stimulating factor), sendo capazes de suportar a hematopoese de linhagens mielóides e de linfócitos B, a partir de CTH (Zúñiga-Pflücker, 2004; Awong et al., 2008). Com morfologia similar a dos fibroblastos, estas células não expressam marcadores de superfícies hematopoéticos como CD45 e CD34 e expressam marcadores típicos de células-tronco mesenquimais (Gao et al., 2010).

A transdução retroviral das células OP9 com o ligante de Notch, Delta-like 1, origina a linhagem celular OP9-DL1, que perde a habilidade de suportar a linfopoiese de células B, e adquire a capacidade de induzir a diferenciação de células progenitoras hematopoéticas em células T (Schmitt et al., 2002; De Smedt et al., 2004; La Motte-Mohs et al., 2005; Pooter \& Zúñiga-Pflücker, 2007; Awong et al., 2008).

Cerca de $1_{x} 10^{4}$ células da linhagem OP9-GFP e OP9-DL1 (cedidas pelo Dr. ZunigaPflucker) foram semeadas em cada poço de uma placa (24 poços de fundo chato) e cultivadas até confluência por 3 dias em estufa de $\mathrm{CO}_{2}(5 \%)$ a $37^{\circ} \mathrm{C}$. Para o cultivo foi utilizado meio $\alpha$-MEM suplementado com $20 \%$ de soro bovino fetal (SBF), $50 \mathrm{U} / \mathrm{mL}$ de penicilina e $50 \mu \mathrm{g} / \mathrm{mL}$ streptomicina.

Após serem selecionadas imunomagneticamente, cerca de $4_{x} 10^{6} \mathrm{CTH} \mathrm{CD}^{+} 4^{+}$são obtidas a partir de uma bolsa de SCU, deste total cerca de $2{ }_{\mathrm{x}} 10^{5}$ células foram semeadas em cada poço, contendo uma monocamada confluente de células estromais OP9-GFP e OP9DL1. As citocinas recombinantes Flt-3L (5 ng/mL) e IL-7 $(5 \mathrm{ng} / \mathrm{mL})$ foram adicionadas no início da cocultura (também realizada a $37^{\circ} \mathrm{C}$ em estufa com $5 \% \mathrm{CO}_{2}$ ) juntamente com as 
CTH CD $34^{+}$, nos experimentos de diferenciação celular, os quais duram em torno de 21 dias, além de iniciarmos o cocultivo com um menor número de $\operatorname{CD} 34^{+}\left(5_{\mathrm{x}} 10^{4}\right)$, realizamos a troca de tapete a cada 8 dias e a troca de meio e reposição das citocinas a cada 4 dias (Figura 7).

Inicialmente, a fim de determinar se, e em que ponto, ocorre variação na expressão dos transcritos propostos, as $\mathrm{CTH} \mathrm{CD} 34^{+}$isoladas foram cocultivadas com as células OP9-GFP e OP9-DL1 por diferentes períodos (2, 12, 24 e 48 horas) sendo a análise efetuada por PCR em tempo real. Após o estabelecimento do tempo de cocultivo, buscamos determinar as concentrações das drogas DAPT (inibitória da via Notch) e BAY11-7082 (inibitória da via NF-kB). Para a droga DAPT testamos quatro concentrações $(10 \mu \mathrm{M}, 25 \mu \mathrm{M}, 50 \mu \mathrm{M}$ e $100 \mu \mathrm{M})$, enquanto que para o BAY avaliamos cinco $(10 \mu \mathrm{M}, 1 \mu \mathrm{M}, 100 \mathrm{nM}, 10 \mathrm{nM}$ e $1 \mathrm{nM})$.

Com o objetivo de melhor compreender os mecanismos envolvidos na regulação transcricional dos alvos avaliados, utilizamos a droga cycloheximide (CHX) (Calbiochem $\left.{ }^{\circledR}\right)$, que bloqueia a síntese protéica em eucariotos. O uso dessa droga permite distinguir entre mecanismos regulatórios primários, que resultam da sinalização mediada por componentes já presentes na célula (ocorrendo mesmo na presença da $\mathrm{CHX}$ ), daqueles dependentes de efeitos secundários (mediados por proteínas sintetizadas de novo (Satterthwaite et al., 1990; Ring et al., 1997; Iso et al., 2001; Bachmann et al., 2007; Sakata et al., 2007; Borggrefe, et al., 2009).

Assim, experimentos empregando ou não o fator agonista da via NF- $\kappa B(T N F-\alpha)$ e o inibidor de síntese protéica, cycloheximide (CHX), em associação ou não com as demais drogas foram realizados posteriormente, a fim de avaliar qual o papel das vias Notch e NF- $\mathrm{B}$ na expressão dos diferentes fatores transcricionais. Visando avaliar o efeito de TNF- $\alpha$ em condições mais próximas às fisiológicas, utilizamos o TNF- $\alpha$ numa concentração de 0,25ng/ml, uma vez que variações de efeitos biológicos em função da concentração deste fator são evidenciadas com concentrações abaixo de cerca de 1ng/ml (Tartaglia , 1993; Corredor, 2002). Em relação ao tratamento com $\mathrm{CHX}$ realizado nas $\mathrm{CTH}$, empregamos a concentração de $10 \mu \mathrm{g} / \mathrm{ml}$ por 2 horas a $37^{\circ} \mathrm{C}$, uma vez que nessas condições há inibição de $95 \%$ da síntese protéica (Figura 8) (Satterthwaite et al., 1990; Sakata et al., 2007; Borggrefe, et al., 2009). 


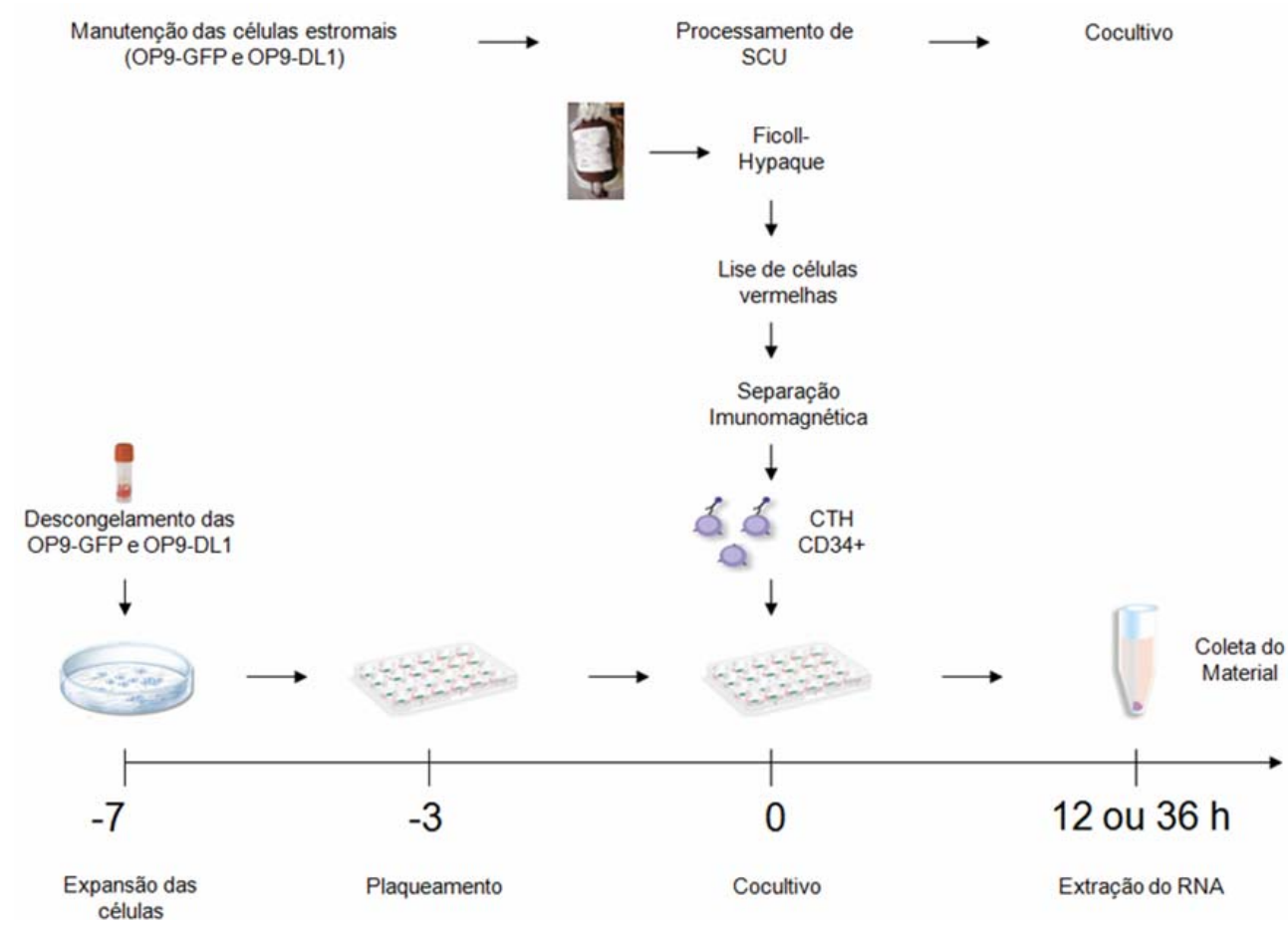

Figura 7. Esquema representante do processamento do $\mathrm{SCU}$, do cultivo das células OP9, além do preparo e manutenção do cocultivo das células $\mathrm{CD} 34^{+}$com as OP9, sempre em presença de IL-7 e Flt3-L, seguindo a linha temporal, até o momento de coleta das amostras e extração do RNA total.

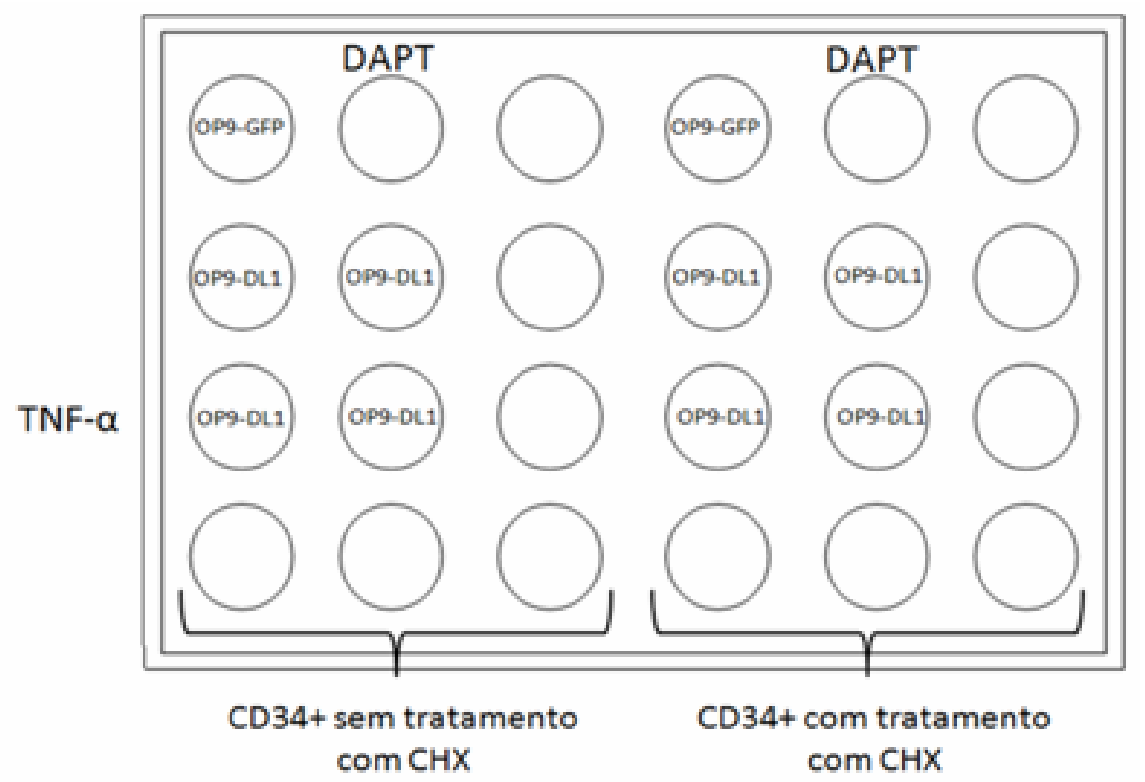

Figura 8. Esquema de montagem da placa de cocultivo, com as células estromais (OP9-GFP e OP9-DL1) e CTH $\mathrm{CD}^{2} 4^{+}$e, a distribuição de todos os tratamentos empregados neste experimento (DAPT $10 \mu \mathrm{M}, 0,25 \mathrm{ng} / \mathrm{ml}$ de TNF- $\alpha$ e CHX). 


\subsection{Avaliação da Diferenciação de Células T por Citometria de Fluxo}

As $\mathrm{CTH} \mathrm{CD}_{3} 4^{+}$recém purificadas e os linfócitos produzidos nas coculturas foram caracterizados por citometria de fluxo, quanto à expressão de marcadores específicos do processo de diferenciação de linfócitos T. As células em cocultura foram recuperadas por ressuspensão. Alíquotas das amostras contendo cerca de $1-2_{\mathrm{x}} 10^{5}$ células foram incubadas com os anticorpos a serem avaliados e com os controles de isotipo. Após incubação em geladeira por 20 minutos, os tubos foram centrifugados por 5 minutos a $2000 \mathrm{rpm}$ a $5^{\circ} \mathrm{C}$, o sobrenadante descartado, e o pellet de células ressuspenso em $2 \mathrm{ml}$ de PBS azida contendo SBF. Os tubos foram novamente centrifugados por 5 minutos a $2000 \mathrm{rpm}$ a $5^{\circ} \mathrm{C}$, o sobrenadante descartado, e o pellet de células ressuspenso em $500 \mu 1$ de PBS formol (1\%) para aquisição das células pelo citômetro (FACScalibur, Becton Dickinson).

O painel para caracterização imunofenotípica foi composto pelos anticorpos antiCD45 APC, anti-CD34 PE, anti-CD1a PerCP e anti-CD7 FITC (PharMingen - BDBiosciences, San Diego-CA). Os linfócitos, $\mathrm{CD}^{+} 5^{+}$(eliminando possíveis células contaminantes da cultura, inclusive as células estromais de camundongos), foram caracterizados visando identificar o percentual de células em processo de diferenciação nas seguintes sub-populações: progenitores mais primitivos $\left(\mathrm{CD} 34^{+} \mathrm{CD} 7^{+} \mathrm{CD} 1 \mathrm{a}^{-}\right)$, progenitores comprometidos com a linhagem $\mathrm{T}\left(\mathrm{CD} 34^{+} \mathrm{CD} 7^{++} \mathrm{CD} 1 \mathrm{a}^{+}\right)$e linfócitos pre-T1 $\left(\mathrm{CD} 34^{+} \mathrm{CD}^{+} \mathrm{CD} \mathrm{a}^{+}\right)$.

\subsection{Extração de RNA}

Após coleta das amostras de cocultivo e separação imunomagnética das células $\mathrm{CD}^{+} 4^{+}$, essas foram ressuspensas em $250 \mu \mathrm{l}$ de PBS $1 \mathrm{X}$ com DEPC (Dietilpirocarbonato; Sigma-Aldrich, Steinhein, Alemanha) e $750 \mu$ de TRIZOL (solução monofásica de fenol e 
isotiocianato de guanidina - Invitrogen, Carlsbad, CA, USA) e mantidas em freezer a $-80^{\circ} \mathrm{C}$ para posterior extração de RNA.

As amostras foram descongeladas e a cada uma foi adicionado $10 \mu \mathrm{l}$ de glicogênio e $200 \mu 1$ de clorofórmio, homogeneizou-se as amostras em vortex e, em seguida, os tubos foram centrifugados a $14000 \mathrm{rpm}$ por 15 minutos a $4^{\circ} \mathrm{C}$. Retirou-se cuidadosamente os anéis formados em cada amostra, transferindo-os a outros tubos, nestes adicionamos $500 \mu \mathrm{de}$ isopropanol gelado e deixamos precipitar em temperatura ambiente por 15 minutos, centrifugamos a $14000 \mathrm{rpm}$ por 15 minutos a $4^{\circ} \mathrm{C}$, e descartamos o sobrenadante. O pellet formado foi ressuspenso em etanol $70 \%$ e centrifugado a $14000 \mathrm{rpm}$ por 10 minutos a $4^{\circ} \mathrm{C}$, descartamos o sobrenadante e ressuspendemos o pellet em $15 \mu l$ de água livre de RNAse. Os RNAs foram congelados em freezer $-80^{\circ} \mathrm{C}$.

\subsection{Quantificação das amostras}

O RNA total obtido das amostras foi quantificado em Nanovue no comprimento de onda de $260 \mathrm{~nm}$, utilizando equivalência de $40 \mu \mathrm{g} / \mathrm{ml}$ para 1 unidade de absorbância. $\mathrm{O}$ grau de pureza das amostras foi avaliado através da razão $260 / 280 \mathrm{~nm}$, sendo considerada uma boa extração aquela que apresentou valores entre 1,6 e 1,8.

\subsection{PCR em Tempo Real}

Parte do RNA extraído (500 ng) de cada amostra foi empregado na síntese do cDNA (25 $\mu 1$ ), realizado por transcrição reversa utilizando o kit "High Capacity cDNA Archive Kit" (Applied Biosystems, Foster City, CA), seguindo as instruções do fabricante. O cDNA por sua fez foi diluído 5 vezes para ser utilizado nas reações de PCR.

Os transcritos diretos de Notch (HEY1 e HES1) e dos potenciais alvos transcricionais (GATA3, USF1, HOXB4, RUNX1, RELA, RELB, NFKB1 e NFKB2) tiveram a expressão 
avaliada, por PCR em tempo real, nas $\mathrm{CTH} \mathrm{CD} 34^{+}$recém purificadas e nas condições de cocultivo.

As reações de PCR em tempo real foram realizadas em duplicata utilizando sondas TaqMan ("Assay on demand") (anexo 3) em conjunto com o reagente MasterMix, em um aparelho 7300 Real Time PCR System (Applied Biosystems, Foster City, CA). As condições de termociclagem compreenderam uma incubação a $50^{\circ} \mathrm{C}$ por 2 minutos, $95^{\circ} \mathrm{C}$ por 10 minutos (para ativação da DNA polimerase), seguidos por 40 ciclos de $95^{\circ} \mathrm{C}$ por 15 segundos (desnaturação) e $60^{\circ} \mathrm{C}$ por 1 minuto (anelamento e extensão simultâneos). Os resultados foram avaliados através do software Sequence Detection System V1.3 para obtenção dos valores de CT, no final das corridas os dados foram então exportados para planilhas do software Excel para cálculo dos valores de $\Delta \mathrm{CT}$.

Posteriormente, os resultados do PCR em tempo real (CTs) para cada transcrito foram normalizados para cada amostra, subtraindo o valor do CT obtido para o controle endógeno GAPDH (obtendo o valor de $\Delta \mathrm{Ct}$ ). Como referência para cálculo de valores de expressão relativa $\left(2^{-\Delta \Delta C t}\right)$ (Pfaffl, 2001), utilizamos a condição de cocultura com OP9-GFP, uma vez que esta representa uma condição mais próxima às outras condições do experimento.

As análises estatísticas foram realizadas através do software GraphPad Prism 5 (GraphPad Software, Inc., San Diego, CA), utilizando testes adequados a cada tipo de análise. Os resultados foram apresentados com média e SEM. A significância estatística foi determinada usando o teste $\mathrm{T}$ não pareado e os resultados foram considerados significativos quando $\mathrm{p} \leq 0,05$. 
4. RESULTADOS 


\subsection{Expansão e produção de estoque das células estromais de camundongo OP9-GFP e} OP9-DL1.

Em nosso laboratório já possuíamos um estoque prévio das linhagens celulares estromais de camundongo OP9-GFP e OP9-DL1, entretanto, as mesmas encontravam-se em diferentes passagens e haviam sido cultivadas sobre diferentes condições. Assim, com o intuito de amenizar as possíveis diferenças ocasionadas por essas variações, refizemos o estoque dessas linhagens, de tal forma, que apenas utilizamos células em quatro diferentes passagens $\left(12^{\mathrm{a}}, 13^{\mathrm{a}}, 14^{\mathrm{a}}\right.$ e $15^{\mathrm{a}}$ passagem $)$. Além disso, realizamos a análise de expressão do marcador de superfície DL1 nas quatro passagens, a fim de confirmar que a taxa de expressão do mesmo não sofria alteração de acordo com a passagem em que a célula se encontrava (Figura 9).
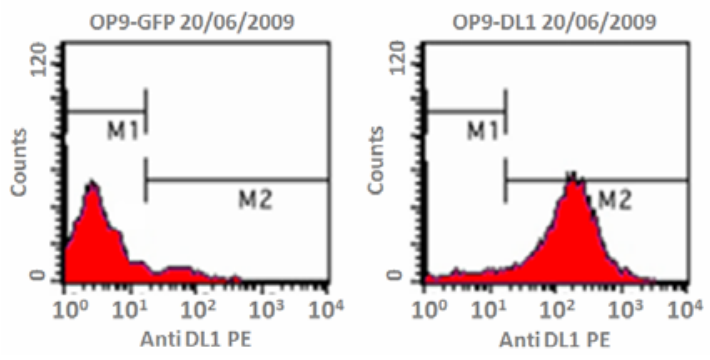

Figura 9. Análise da expressão do marcador de superfície DL1, nas células estromais de camundongo OP9-GFP e OP9-DL1. Podemos observar que as primeiras praticamente não expressam tal marcador (aproximadamente 10\%), enquanto, que as células OP9-DL1 evidenciaram uma taxa de expressão do marcador de aproximadamente $90 \%$, independentemente da passagem em que as células estromais se encontravam.

\subsection{Análise da pureza das amostras de células-tronco hematopoéticas CD34 ${ }^{+}$isoladas do sangue de cordão umbilical.}

Após o recebimento e processo do SCU realizamos a análise da pureza de todas as amostras, por citometria de fluxo, levando em conta a porcentagem de células CD34 ${ }^{+}$ (principal marcador das $\mathrm{CTH}$ ) seguindo o protocolo descrito anteriormente (Figura 10). De 
acordo com essas análises, podemos afirmar que trabalhamos com uma pureza de CD34 variando entre 71,56 e $95,41 \%$, sendo que a média foi de $87,45 \%$.
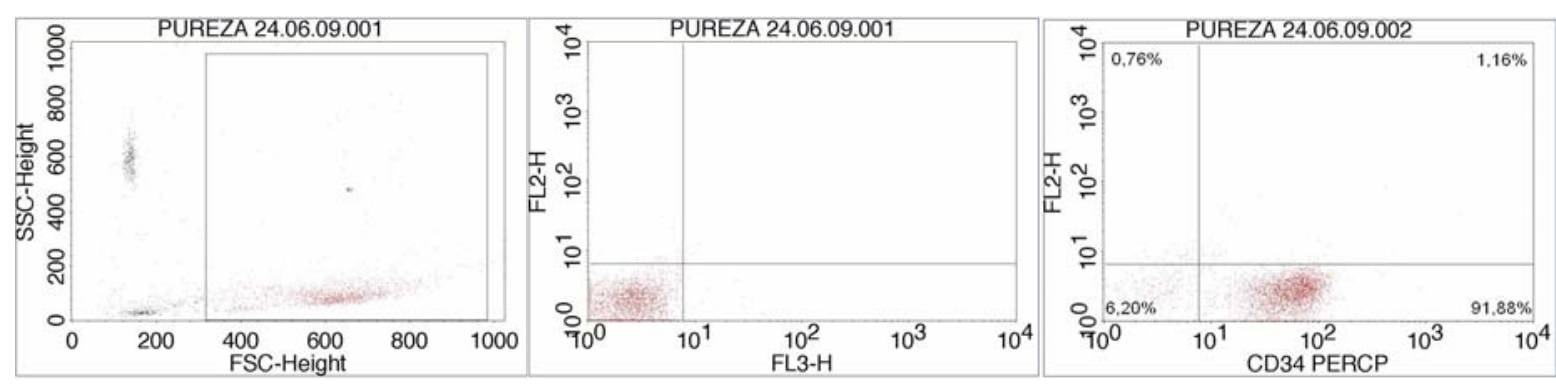

Figura 10. Análise da pureza das células-tronco hematopoéticas $C D 34^{+}$após separação imunomagnética a partir de amostra de sangue de cordão umbilical.

\subsection{Determinação da especificidade dos ensaios de PCR em tempo Real na amplificação de transcritos das células-tronco hematopoéticas de humanos em presença de transcritos de células estromais de camundongos.}

Durante a realização desse trabalho, verificamos que ao longo do cocultivo, as célulastronco hematopoéticas $\mathrm{CD} 34^{+}$de humanos se aderem fortemente às células estromais de camundongos OP9-GFP e OP9-DL1. Esta aderência dificulta a recuperação exclusiva das células-tronco hematopoéticas por simples pipetagem e nos levou a adotar outra estratégia para a realização das análises.

Passamos a coletar tanto as células estromais de camundongo como as células-tronco hematopoéticas humanas $\mathrm{CD} 34^{+}$, extraindo o RNA conjuntamente. Para garantir que isso não afetaria as análises efetuadas neste trabalho, realizamos ensaios, utilizando RNA das células estromais de camundongos (OP9-GFP e OP9-DL1), testando a especificidade de todas as sondas de interesse, inclusive de dois genes endógenos humanos (GAPDH e $\beta$-actina). Com isso, constatamos que nenhuma das sondas humanas amplificou o cDNA obtido das células de camundongo, o que permitiu desprezar a influência de possíveis contaminações por estas células. 
Para garantir que os resultados não seriam influenciados pela presença e, consequentemente, pela diluição das células-tronco hematopoéticas $\mathrm{CD}^{+} 4^{+}$nas células estromais de camundongo (tanto OP9-GFP, quanto OP9-DL1), realizamos outro teste para confirmar a sensibilidade das sondas. Neste, utilizamos o RNA isolado a partir das célulastronco hematopoéticas $\mathrm{CD} 34^{+}$fresca e o RNA das células estromais de camundongo OP9GFP e OP9-DL1, além de realizar diversas diluições (de 10x, 100x 1000x, 10000x e 100000x) do RNA das $\mathrm{CTH} C D 34^{+}$no RNA das células de camundongo. Após as diluições, realizamos a transcrição reversa de todas as condições, para então, avaliarmos os resultados por PCR em tempo real (Figura 11).

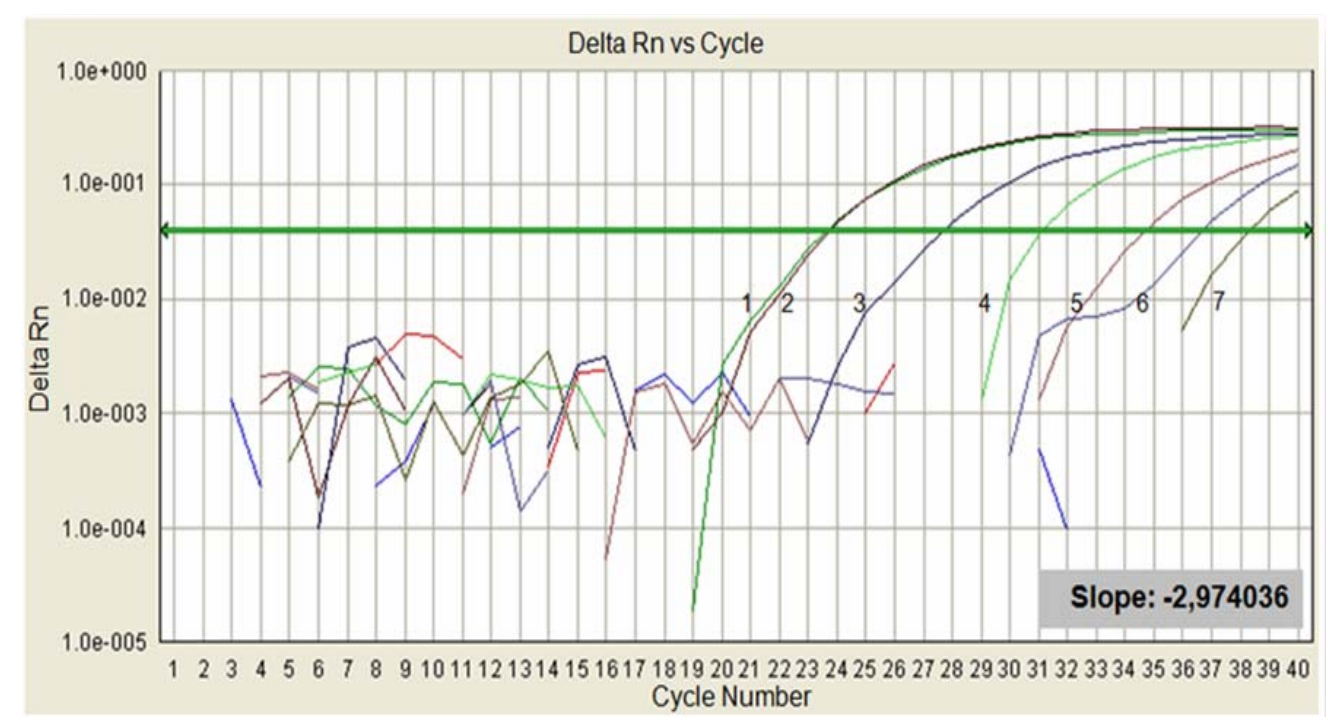

Figura 11. Imagem representativa da eficiência das sondas empregadas neste trabalho (curvas referente à sonda GAPDH). Podemos verificar que não houve amplificação das sondas humanas para as condições em que apenas as células de camundongo (tanto OP9-GFP, quanto OP9-DL1) estavam presentes (indicado pelo ruído). Todas as demais condições apresentaram curva de amplificação, sendo que a curva 1 representa a amostra de $\mathrm{CD}_{3} 4^{+}$pura; a curva 2 representa as $\mathrm{CD}^{+} 4^{+}$em presença da mesma quantidade das OP9-DL1; a curva 3 indica a diluição de 10x; a curva 4 representa a diluição de $100 x$; a curva 5 ilustra a diluição de 1000x; a curva 6 corresponde a diluição de 10000x; e a curva 7 representa a diluição de 100000x. Podemos ainda calcular a eficiência das sondas através do slope (fornecido pelo programa do Real Time PCR). Para todas as sondas utilizadas, a eficiência foi superior a $100 \%$.

Observamos que a taxa de expressão das células $\mathrm{CD}^{+} 4^{+}$em presença ou não das células OP9 não sofria alteração e, que as amplificações das amostras diluídas ocorriam com 
atraso de 3CTs ao longo da diluição seriada, evidenciando que as sondas possuem uma elevada sensibilidade e eficiência (slope $=-2,97 ; \mathrm{E}=2,16$ ). Desta forma, podemos concluir que a coleta de todas as células do cocultivo (ou seja, a coleta das $\mathrm{CTH} \mathrm{CD} 34^{+}$e das células OP9) e a extração conjunta do RNA não interfere em nossos resultados finais sendo, portanto, viável as análises de expressão gênica.

\subsection{Caracterização do sistema de cocultivo das CTH com as células OP9.}

Inicialmente realizamos um experimento a fim de garantir que o sistema de cocultivo das células-tronco hematopoéticas $\mathrm{CD}^{+} 4^{+}$com as células OP9-DL1 produziria células comprometidas com a linhagem linfocítica T, enquanto que a cocultura com a linhagem OP9GFP não apresentaria tal habilidade (Figura 12).

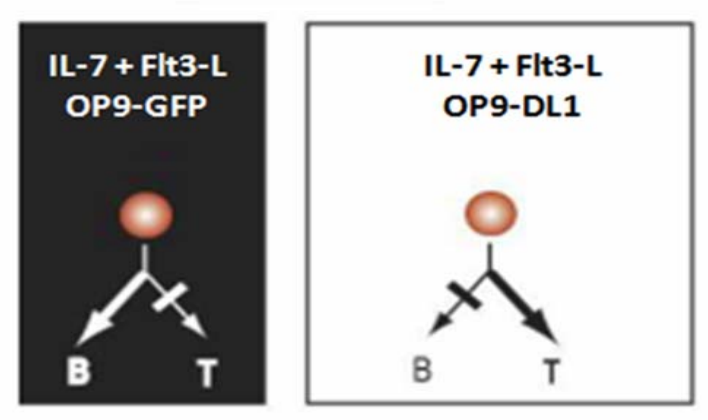

Figura 12: Destino das $\mathrm{CTH} C \mathrm{CD} 34^{+}$cocultivadas com as células estromais murinas OP9-GFP e OP9-DL1 na presença das citocinas IL-7 e Flt3-L. Evidenciando que o cocultivo das CTH com a linhagem OP9-GFP leva a produção de células B, enquanto que o cocultivo com a linhagem OP9-DL1 leva a produção de células $\mathrm{T}$.

De acordo com esse experimento, podemos certificar-nos que apenas o cocultivo com as células estromais de camundongo OP9-DL1 consegue gerar grande quantidade de células $\mathrm{CD}^{+}$já com 12 dias de cocultivo, enquanto que a porcentagem de células com esse fenótipo geradas pelo cocultivo com as células OP9-GFP é bastante reduzido (Figura 13). 

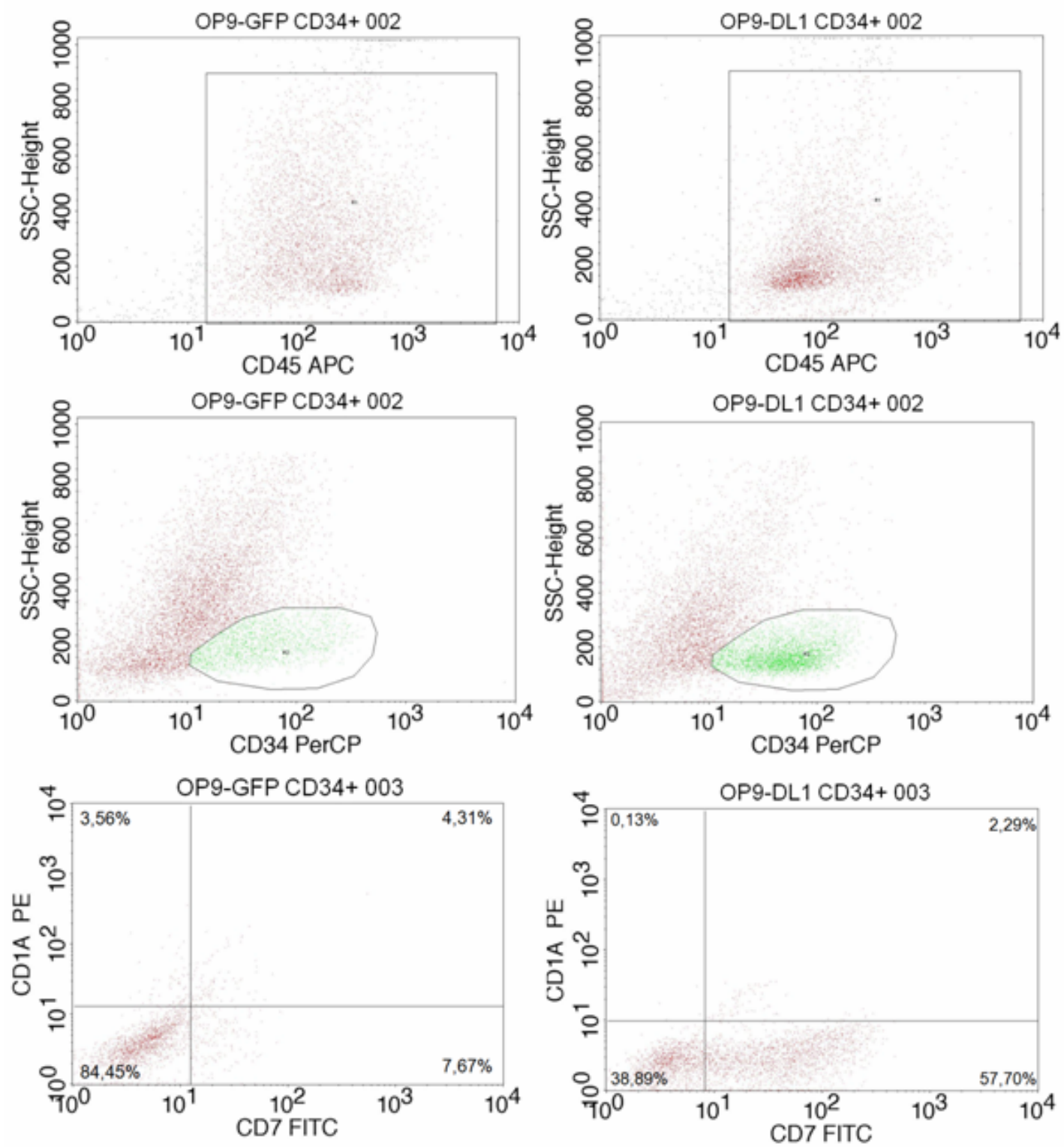

Figura 13. Análise da diferenciação das $\mathrm{CTH} \mathrm{CD} 34^{+}$em linfócitos $\mathrm{T}$ por citometria de fluxo. As $\mathrm{CTH} \mathrm{CD} 34^{+}$ selecionadas imunomagneticamente de sangue de cordão umbilical foram cocultivadas com OP9-GFP e OP9-DL1 e a expressão de CD7 e CD1a foi avaliada após o $12^{\circ}$ dia. Para isso, utilizamos a seguinte marcação: um tubo contendo os controles inespecíficos IgG1 APC e IgG1 PerCP, um tubo contendo antiCD45 APC e anti-CD34 PerCP, um tubo contendo IgG1 FITC e IgG1 PE e outro contento anti-CD1a PE e anti-CD7 FITC a fim de traçar as gates. As porcentagens presentes em cada quadrantes representam o total de células de cada tipo.

Após esse experimento prévio, realizamos mais três experimentos com amostras independentes os quais foram mantidos em cocultivo por 24 dias, e nos quais realizamos as análises acima, a fim de acompanhar o processo de diferenciação. 
De acordo com esses experimentos podemos confirmar que apenas o sistema de cocultivo com as OP9-DL1 é eficaz para a diferenciação de CTH CD34 $4^{+}$em linfócitos T, isso porque em cocultivo com as OP9-GFP uma baixa porcentagem de células $\mathrm{CD}^{+}$e $^{\mathrm{CD} 1 \mathrm{a}^{+}}$foi gerada, enquanto que em cocultivo com as OP9-DL1 verificamos que elevada porcentagem de expressão dos primeiros marcadores de superfície, os quais indicam o comprometimento celular das CTH, CD7 e CD1a. Ainda de acordo com esses experimentos, podemos afirmar que a porcentagem de $\mathrm{CD}^{+}$aumenta com o decorrer do tempo, assim como a porcentagem de $\mathrm{CD} \mathrm{a}^{+}$e principalmente de $\mathrm{CD}^{+} \mathrm{CD}^{-} \mathrm{a}^{+}$(progenitor comprometido com a linhagem de células T) (Gráfico 1).
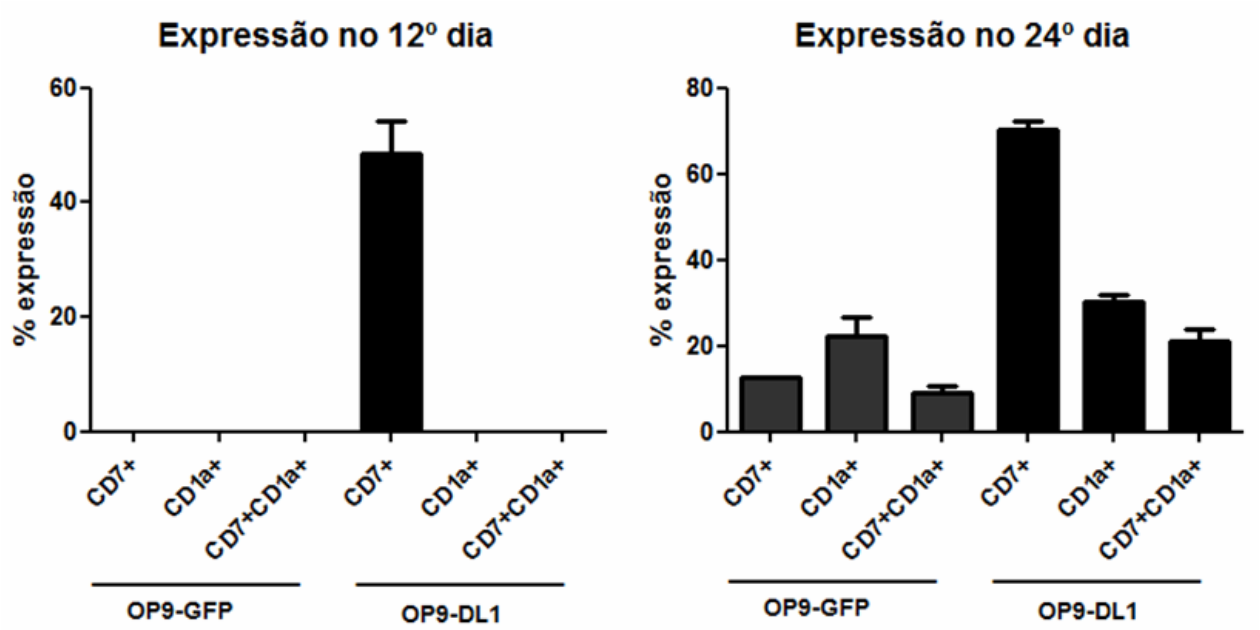

Gráfico 1. Análise da diferenciação celular das células-tronco hematopoéticas $\mathrm{CD} 34^{+}$em cocultivo com as células OP9-GFP e OP9-DL1, com 12 e 24 dias de cocultivo. Avaliando a expressão dos marcadores de superfície CD7 e CD1a. Além de evidenciar a porcentagem de células comprometidas com a linhagem linfocítica $\mathrm{T}\left(\mathrm{CD}^{+} \mathrm{CD} 1 \mathrm{a}^{+}\right)$.

Considerando a condição de diferenciação que recebeu pré-tratamento de 12 horas com TNF- $\alpha(0,25 \mathrm{ng} / \mathrm{ml})$, podemos observar que a diferença das porcentagens dos tipos celular não é diferente significativamente $(\mathrm{p}>0,05)$ das verificadas sem o devido tratamento (Gráfico 2). 


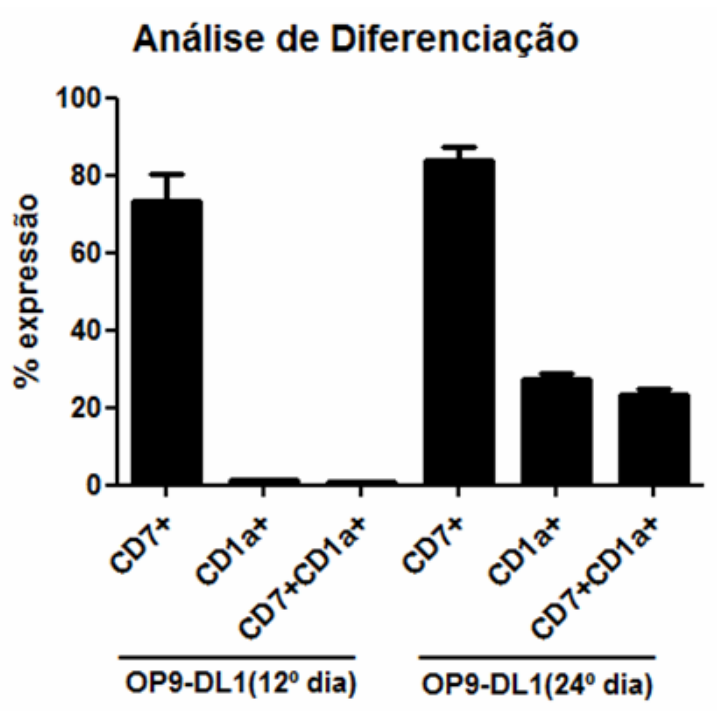

Gráfico 2. Análise da diferenciação celular das células-tronco hematopoéticas $\mathrm{CD} 34^{+}$em cocultivo com as células OP9-DL1 durante 12 dias e 24 dias, em presença do pré-tratamento por 12 horas com TNF- $\alpha$. Avaliando a expressão dos marcadores de superfície CD7 e CD1a, além de evidenciar a porcentagem de células comprometidas com a linhagem linfocítica $\mathrm{T}\left(\mathrm{CD} 7^{+} \mathrm{CD} 1 \mathrm{a}^{+}\right)$.

\subsection{Padronização das concentrações das drogas e do tempo para a avaliação da}

\section{transcrição dos alvos de interesse.}

A fim de avaliarmos a expressão dos transcritos de interesse no sistema de cocultivo, primeiramente fez-se necessário o estabelecimento do tempo ideal para a realização das análises, assim como, a padronização das concentrações das drogas empregadas nesse trabalho. Como a literatura evidencia a importância da via de sinalização Notch na linfopoese T, buscamos avaliar inicialmente a transcrição de um dos alvos diretos dessa via, o HEY1, a fim de verificar em que momento ocorre a ativação da via Notch sob as condições de cocultivo. Para isso, utilizamos diferentes intervalos de cocultivo $(2,12,24$ e 48 horas $)$ das CTH CD $34^{+}$com as células OP9-GFP e OP9-DL1, de acordo com metodologia previamente descrita.

Observamos que apesar de haver transcrição de HEY1 com 2 horas de cocultura (duas vezes mais expresso nas células hematopoéticas cocultivadas com as OP9-DL1, quando comparada à cocultura com OP9-GFP), é com 12 horas que esta diferença tem um aumento significativamente maior (sete vezes) (Gráfico 3). Verificamos ainda, uma redução nos níveis 
de transcrição de HEY1 com 24 horas de cocultivo isso, provavelmente, se deve a flutuações da taxa de expressão desse transcrito. Com 48 horas de cocultivo um novo aumento, ainda maior do que o observado com 12 horas, foi constatado.

\section{HEY1}

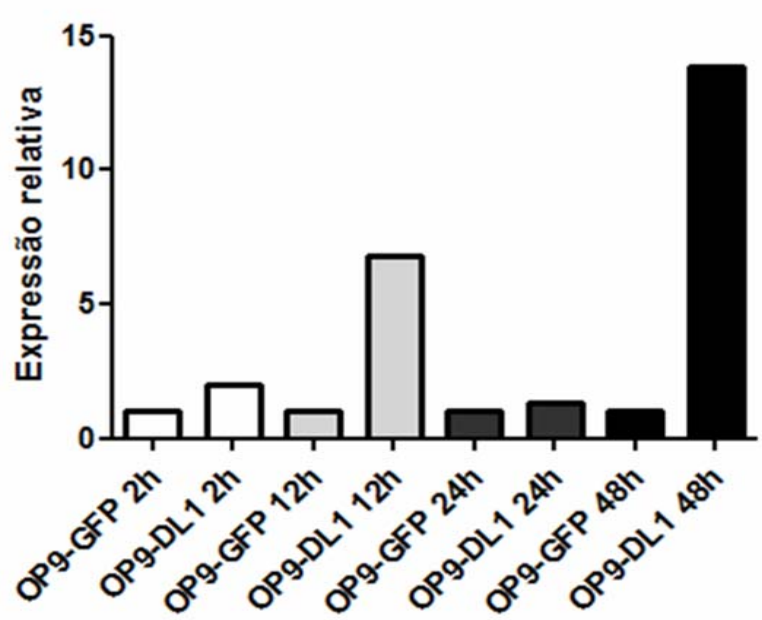

Gráfico 3. Avaliação temporal da transcrição de HEY1. A expressão do gene alvo da via Notch (HEY1) foi avaliada em diferentes tempos (2, 12, 24 e 48 horas) de cocultivo, utilizando as respectivas condições de cocultivo das células-tronco hematopoéticas $\mathrm{CD} 34^{+}$com as células OP9-GFP como referência para o cálculo da expressão relativa das condições de cocultivo das CTH com as OP9-DL1.

Com base nestes resultados, estabelecemos o tempo de 12 horas de cocultivo como o ideal para a realização dos ensaios posteriores, mesmo de posse da informação de que com 48 horas a taxa de transcrição de HEY1 era superior a de 12 horas. Isso devido ao nosso interesse pelas primeiras respostas ocasionadas pela via de sinalização de Notch, responsável pelo início do processo de diferenciação.

Em seguida, buscamos determinar a concentração da droga farmacológica (DAPT) suficiente para inibir a via Notch. Para isso, quatro concentrações da droga $(10 \mu \mathrm{M}, 25 \mu \mathrm{M}$, $50 \mu \mathrm{M}$ e $100 \mu \mathrm{M})$ foram avaliadas após 12 horas de cocultivo.

Com isso, verificamos que a concentração mínima da droga DAPT, necessária para inibir a transcrição de HEY1 com 12 horas de cocultura, correspondeu à menor concentração utilizada em nosso experimento $(10 \mu \mathrm{M})$ (Gráfico 4), e esta concentração foi utilizada em todos os experimentos subsequentes. 


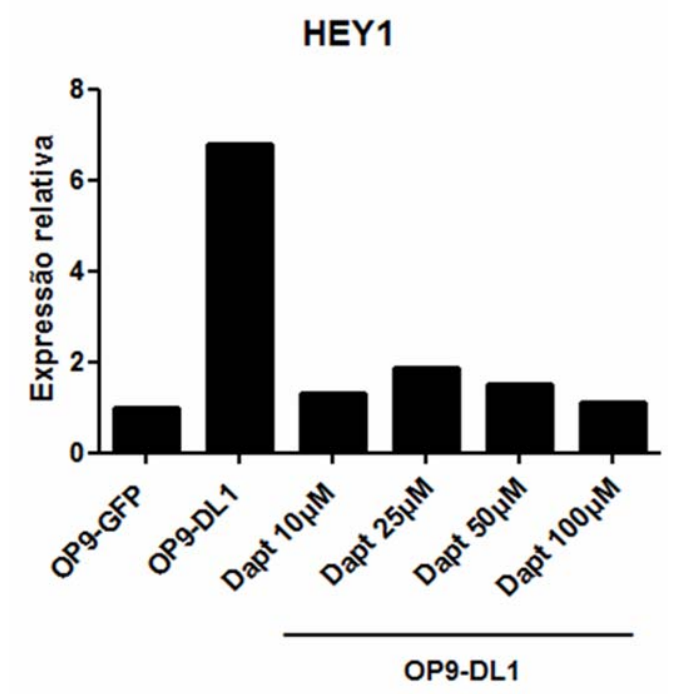

Gráfico 4. Determinação da concentração inibitória da droga DAPT. A ação da droga DAPT em diferentes concentrações $(10 \mu \mathrm{M}, 25 \mu \mathrm{M}, 50 \mu \mathrm{M}$ e $100 \mu \mathrm{M})$ foi avaliadas após 12 horas de cocultivo para determinar a concentração mínima suficiente para inibir a transcrição do alvo conhecido da via Notch (HEY1).

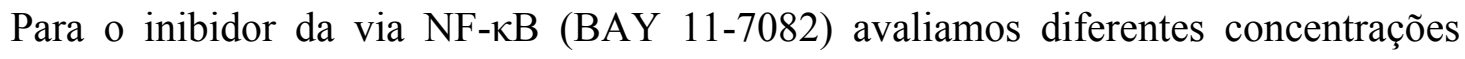
$(10 \mu \mathrm{M}, 1 \mu \mathrm{M}, 100 \mathrm{nM}, 10 \mathrm{nM}$ e $1 \mathrm{nM})$ num período de 12 horas de cocultivo, já que esse tempo havia sido definido anteriormente. Porém, essa droga mostrou-se bastante tóxica as células, proporcionando apoptose e, portanto, interferindo em demasia na viabilidade das células. Assim, resolvemos desconsiderar os resultados obtidos com as células tratadas com o BAY, pois esses seriam influenciados pelo nível de degradação das células e, portanto, não representariam diretamente o efeito da ausência da via de sinalização NF-אB.

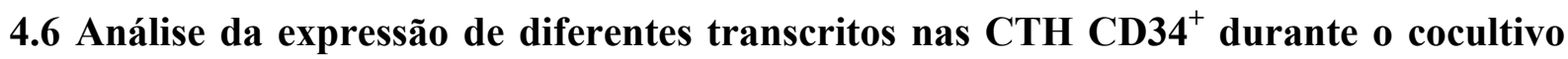 com as células OP9.}

Após o estabelecimento do tempo de cocultivo e da concentração satisfatória da droga DAPT, realizamos nove experimentos independentes a fim de avaliarmos a variação na expressão de diferentes transcritos. Nestes, empregamos a droga inibidora da via Notch

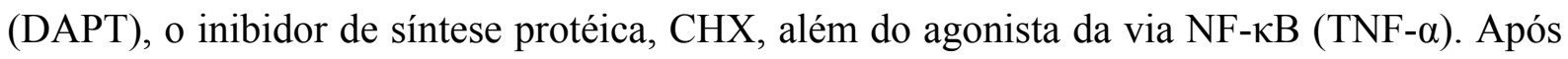
cocultivo de 12 horas, sob as diferentes condições, coletamos as amostras e extraímos o RNA total de cada condição, para posterior análise de expressão gênica por PCR em tempo real. 


\subsubsection{Análise da expressão de HEY1 com 12 horas de cocultivo.}

A análise do cocultivo por PCR em tempo real permitiu inferir que o sistema de cocultivo OP9-DL1 é eficaz na ativação da transcrição de HEY1, isso porque quando comparamos o cocultivo das $\mathrm{CTH} \mathrm{CD} 34^{+}$com as OP9-DL1 a taxa de expressão deste transcrito é superior a verificada no cocultivo com as OP9-GFP (Gráfico 5). Isso ocorre, pois apenas as células OP9DL1 apresentam o ligante de Notch (Delta-Like 1) e, consequentemente, possuem a habilidade de induzir a expressão de genes alvo de Notch, como o HEY1.

A dependência da via de sinalização Notch na transcrição de HEY1 também pode ser inferida através da condição de cocultivo com a droga DAPT. Isso porque, quando empregamos a droga inibitória da via Notch, a taxa de transcrição de HEY1 sofre drástica redução, quando comparada a taxa de expressão verificada no cocultivo das OP9-DL1 com as CTH CD34 $4^{+}$(Gráfico 5). Isso é devido ao fato do DAPT impedir a ação da enzima $\gamma$ secretase, que é responsável por uma das clivagens dos receptores Notch, que libera o NICD para o núcleo. Assim, na presença de DAPT, a via Notch fica interrompida e se comporta como nas células OP9-GFP, implicando em baixa taxa de transcrição de HEY1.

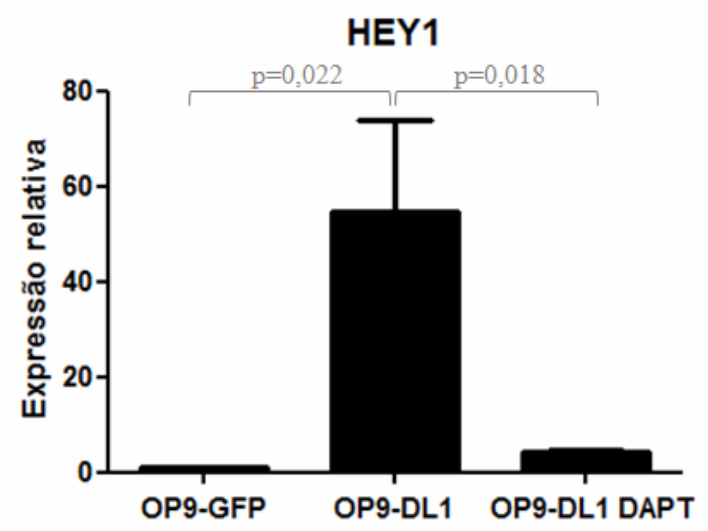

Gráfico 5. Análise da expressão do transcrito HEY1, evidenciando a dependência da via de sinalização Notch para sua transcrição, através do cocultivo das CTH CD34 ${ }^{+}$com as células OP9-DL1 (células OP9 que foram transduzidas com o ligante de Notch, Delta-like 1), e tendo confirmação pelo uso do inibidor da via Notch (DAPT). 
Também podemos deduzir que a ativação de HEY1 não depende da síntese protéica, pois quando pré-tratamos as $\mathrm{CD}_{3} 4^{+}$com $\mathrm{CHX}$ e cocultivamos com as células OP9-DL1 a expressão de HEY1 ainda é significativamente superior a verificada na condição de cocultivo de OP9-GFP com $\mathrm{CD} 4^{+}$sem pré-tratamento. No entanto, as proteínas sintetizadas ao longo do cocultivo atuam de forma positiva sobre a expressão deste fator, pois, quando as célulastronco hematopoéticas $\mathrm{CD} 34^{+}$recebem pré-tratamento com a droga $\mathrm{CHX}$, a taxa de expressão de HEY1 sofre redução quando comparada a taxa do cocultivo apenas com as OP9-DL1 $(\mathrm{p}=0,054)($ Gráfico 6).

Mediante a inibição da via Notch por DAPT, a inibição da síntese protéica por prétratamento com CHX não causa uma redução adicional significativa no nível de expressão de HEY1, indicando que as proteínas sintetizadas de novo atuariam positivamente na transcrição deste fator, principalmente através da modulação direta da sinalização pela via Notch (Gráfico 7).

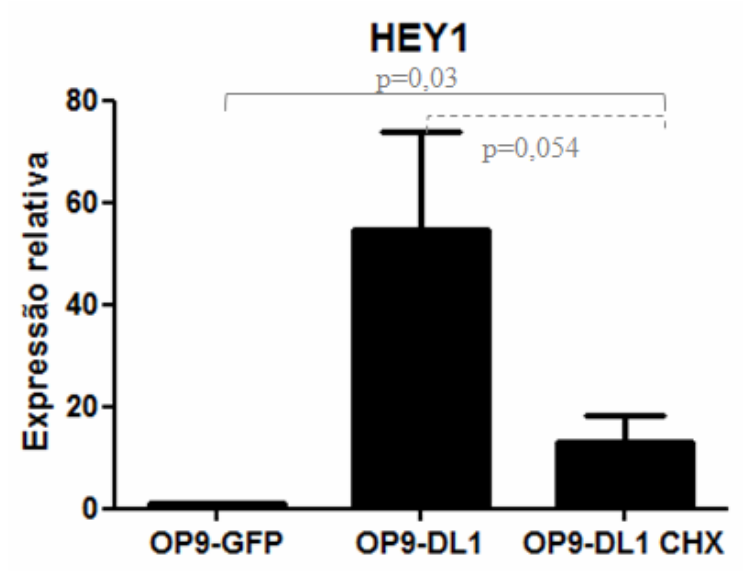

Gráfico 6. A análise da transcrição de HEY1, além de ser dependente da via Notch, evidencia independência da síntese protéica para a ativação da expressão desse fator transcricional. 


\section{HEY1}

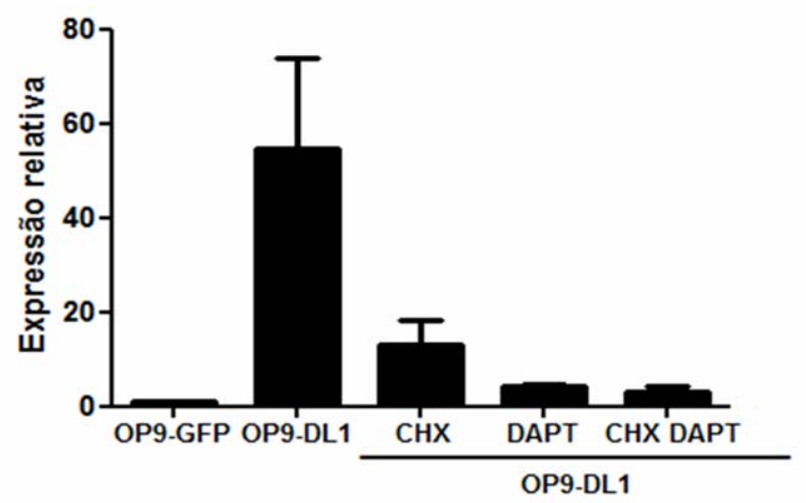

Gráfico 7. O cocultivo conjunto das CTH pré-tratadas com CHX e o uso da droga DAPT indicam que as proteínas sintetizadas de novo atuariam positivamente na transcrição deste fator.

Por outro lado, apesar do uso de TNF- $\alpha(0,25 \mathrm{ng} / \mathrm{ml})$ não ter efeito aparente sobre a transcrição de HEY1, tanto na ausência como na presença de CHX (Gráfico 8); com a inibição da via Notch (DAPT), o TNF- $\alpha$ causa um aumento perceptível na expressão de HEY1 $(p=0,09)$ (Gráfico 9); o efeito da inibição da síntese protéica sobre a redução na expressão de HEY1 é mais evidente (estatisticamente significativo) nas células pré-tratadas com TNF- $\alpha$, mesmo com a inibição da via Notch (Gráfico 10). Assim, TNF- $\alpha$ exerce um efeito positivo sobre a transcrição de HEY1, independente da via Notch, e mediado por proteínas sintetizadas de novo.

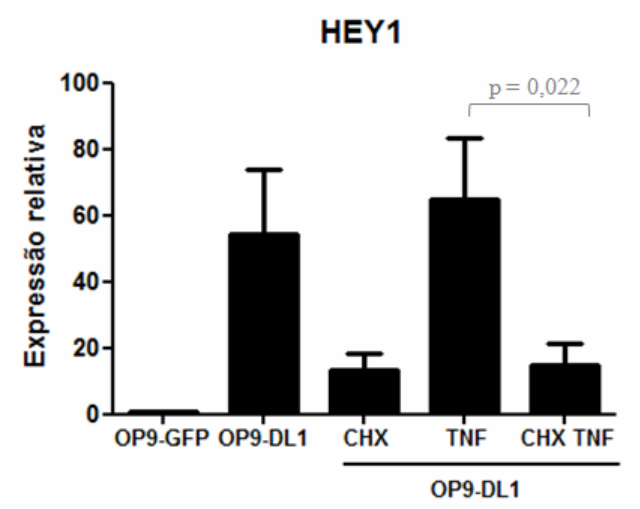

Gráfico 8. Avaliando o papel desempenhado por TNF- $\alpha$, na transcrição de HEY1, aparentemente não observamos atuação deste, nem na presença, nem em ausência do pré-tratamento com CHX. 


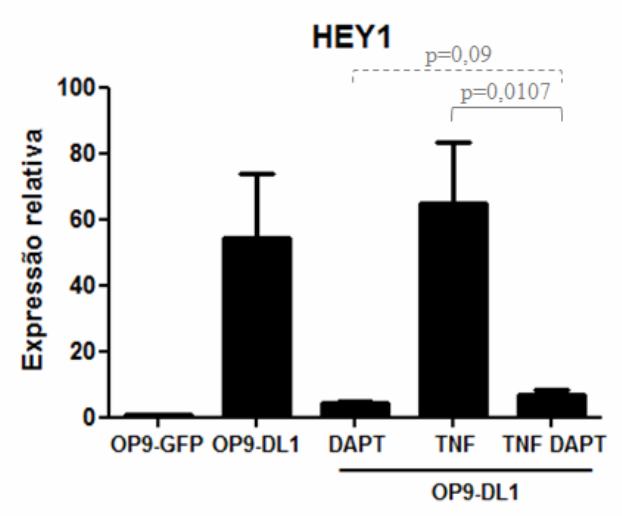

Gráfico 9. Papel positivo de TNF- $\alpha$ na expressão de HEY1, comprovado através do tratamento concomitante do cocultivo com TNF- $\alpha$ e DAPT (inibidor da via Notch).



Gráfico 10. A ação do pré-tratamento com CHX nas CTH conjuntamente com TNF- $\alpha$, evidencia que a inibição da síntese protéica implica em redução na expressão de HEY1, mesmo com a inibição da via Notch, comprovando o efeito positivo de TNF- $\alpha$, mediada por proteínas sintetizadas e de forma independente de Notch. 


\subsubsection{Análise da expressão de HES1 com 12 horas de cocultivo.}

Tal qual o observado para HEY1, a transcrição de HES1 foi induzida nas CTH CD34 cocultivadas com as células OP9-DL1 (comparado ao cocultivo com células OP9-GFP) e; mediante inibição da via Notch por DAPT, a indução transcricional não ocorreu, como esperado para este alvo transcricional de Notch (Gráfico 11).

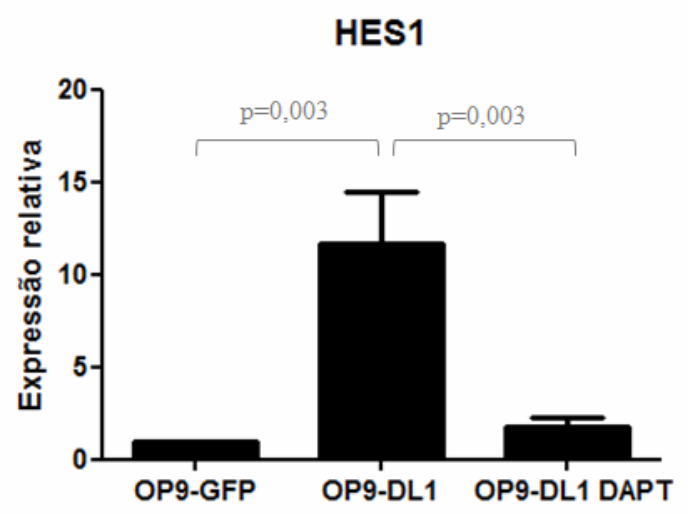

Gráfico 11. A análise da transcrição de HES1, no cocultivo das CTH CD34 ${ }^{+}$com a linhagem OP9-DL1 (portadora do ligante de Notch), evidencia a participação da via de sinalização Notch no controle transcricional desse fator, e esse controle é confirmado através do uso de DAPT (inibidor de Notch).

Contudo, uma grande diferença foi observada em relação à transcrição de HES1, pois em presença de CHX a indução transcricional de HES1 é intensificada (de maneira oposta a observada na transcrição de HEY1), porém sem diferença estatística significante $(0,09)$. Este resultado indica que a $\mathrm{CHX}$ atua bloqueando a síntese de proteínas com ação inibitória sobre a transcrição de HES1 (Gráfico 12).

O efeito positivo da inibição da síntese protéica (pelo uso da $\mathrm{CHX}$ ), sobre a transcrição de HES1, também é observado mediante a inibição da via Notch $(p=0,09)$, indicando que as proteínas sintetizadas de novo, durante o período avaliado, não atuariam diretamente na via Notch (Gráfico 13). 


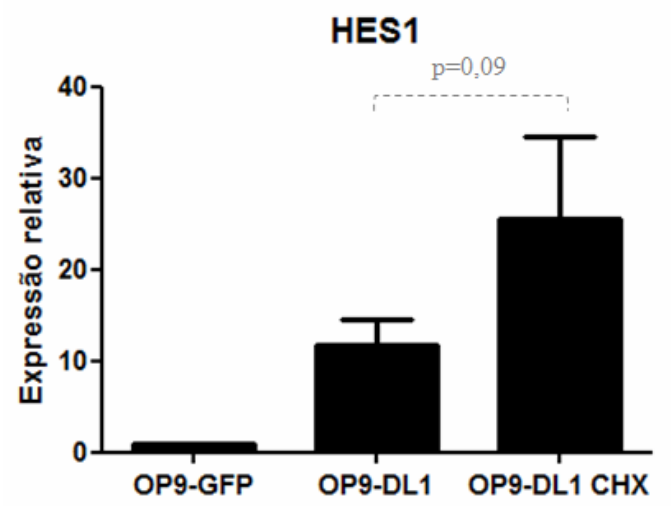

Gráfico 12. O pré-tratamento das CTH com a droga CHX permite inferir que a inibição da síntese protéica atua de forma positiva na transcrição de HES1.

\section{HES1}

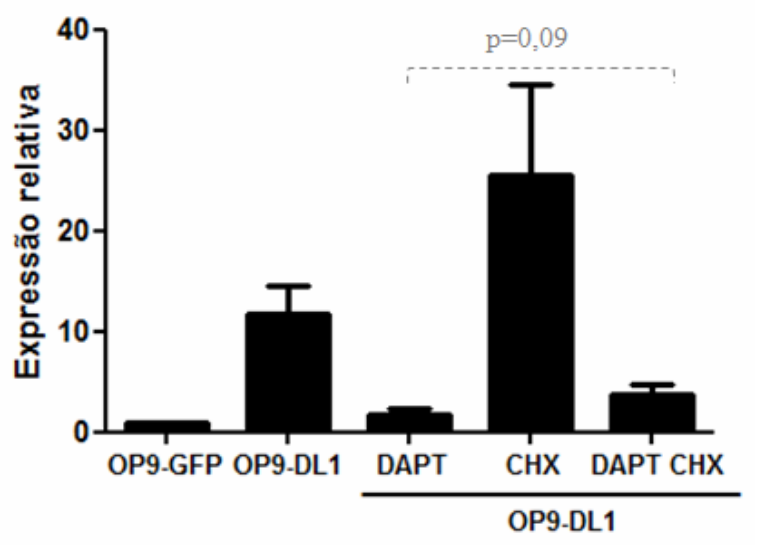

Gráfico 13. A ação de DAPT nas células CTH que receberam o pré-tratamento com a CHX evidencia que as proteínas sintetizadas não atuam de forma direta sobre a via Notch.

Ao avaliarmos o papel de TNF- $\alpha(0,25 \mathrm{ng} / \mathrm{ml})$ observamos um comportamento heterogêneo nos experimentos sem alteração significativa no nível de HES1, tanto na presença quanto na ausência de DAPT (Gráfico 14), como na presença ou ausência de CHX (Gráfico 15). Apesar de não detectarmos uma ação significativa do TNF- $\alpha$ nas condições mencionadas acima, na presença de TNF- $\alpha$ o efeito positivo do tratamento com a CHX, sobre a expressão de HES1, é reduzido. Isto indicaria que a inibição da síntese protéica de novo (pela CHX) estaria sendo contrabalanceada pela indução da síntese de proteínas com efeito negativo sobre a transcrição de HES1, mediada pelo TNF- $\alpha$. Finalmente, na presença de TNF- 
$\alpha$ e DAPT, o efeito positivo da inibição da síntese protéica (pela $\mathrm{CHX}$ ) sobre a transcrição de HES1 passa a ser significativo (Gráfico 15). Em suma, os resultados indicam que existe um efeito negativo de TNF- $\alpha$ sobre a transcrição de HES1, independente da via Notch, e mediado por proteínas sintetizadas de novo.

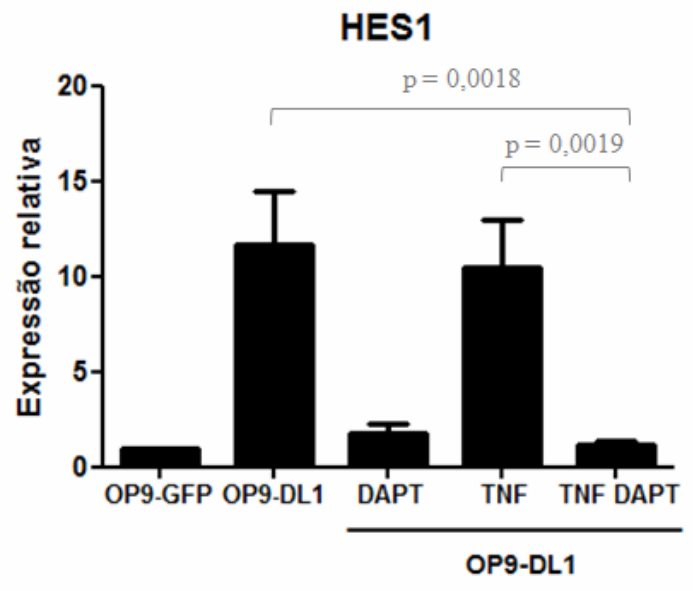

Gráfico 14. O TNF- $\alpha$ comportou-se de forma bastante heterogênea em relação à transcrição de HES1, tanto na presença, quanto na ausência da via Notch.

\section{HES1}

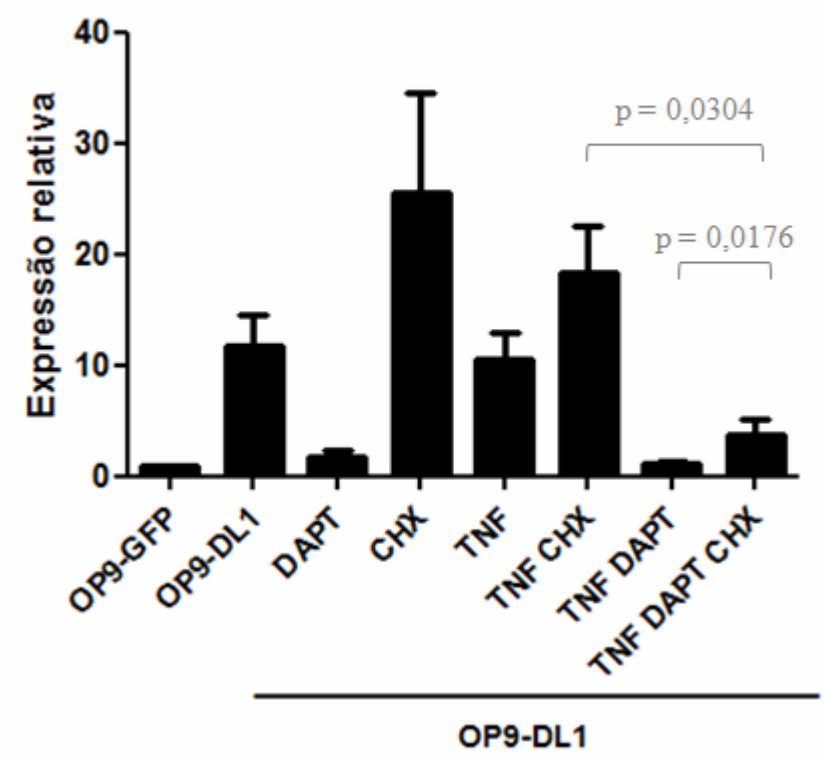

Gráfico 15. A ação da $\mathrm{CHX}$, possivelmente, seria contrabalanceada pela indução da síntese protéica, com efeito negativo sobre a transcrição de HES1, mediada pelo TNF- $\alpha$. Evidenciando efeito negativo de TNF- $\alpha$ sobre a transcrição de HES1, independente da via Notch, e mediado por proteínas sintetizadas de novo. 


\subsubsection{Análise da expressão de GATA3 com 12 horas de cocultivo.}

Ao avaliarmos a expressão de GATA3 nas CTH cocultivadas com as células OP9DL1, observamos uma pequena, porém significativa indução que, no entanto, não foi impedida pela inibição da via Notch (através do uso de DAPT), caracterizando uma indução não dependente da via Notch (Gráfico 16).

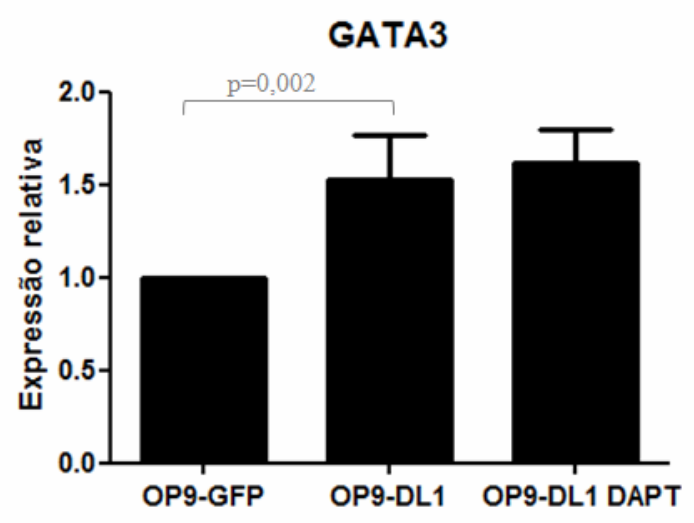

Gráfico 16. Análise da expressão de GATA3, evidenciando a participação parcial da via Notch no controle dessa transcrição, pois há indução desse fator no cocultivo com as OP9-DL1 (portadoras do ligante de Notch), porém em ausência da via Notch (com o uso de DAPT) não há a repressão.

Ao avaliarmos a ação de TNF- $\alpha$ sobre a transcrição de GATA3 observamos um efeito positivo, com aumento significativo na transcrição desse fator (Gráfico 17). A inibição da síntese protéica (utilizando a CHX) também implicou num aumento dos níveis de GATA3, mas sem significância estatística $(\mathrm{p}=0,06)$ (Gráfico 17), indicando o bloqueio da síntese de proteínas com efeito negativo sobre a transcrição de GATA3. Em linha, na presença concomitante da CHX e do TNF- $\alpha$ ocorreu um aumento significativo ainda maior dos níveis de GATA3, demonstrando ainda, que a ação positiva de TNF- $\alpha$ sobre a transcrição de GATA3 é independente da síntese de novo de proteínas e, portanto, mediada por mecanismos de sinalização presentes na célula (Gráfico 17). 


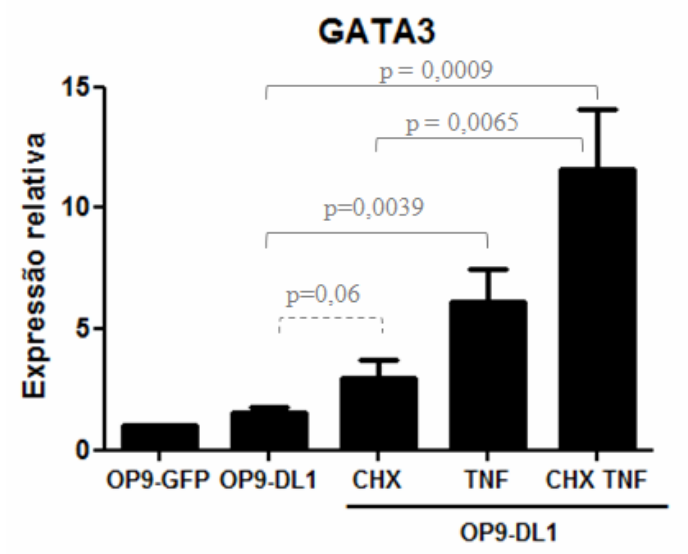

Gráfico 17. Observamos efeito positivo de TNF- $\alpha$, e CHX sobre a transcrição de GATA3 e, principalmente, do uso concomitante dos mesmos, evidenciando que a ação positiva de TNF- $\alpha$, é independente da síntese de novo de proteínas e, portanto, mediada por mecanismos de sinalização presentes na célula.

Ao avaliarmos o efeito da inibição da via Notch (com uso de DAPT) em células tratadas com TNF- $\alpha$, com CHX ou por ambos, evidenciamos que o efeito positivo de TNF- $\alpha$ sobre a transcrição de GATA3 ocorre por mecanismos atuando diretamente sobre a via Notch (independente de efeitos secundários mediados por proteínas sintetizadas de novo), como indicado pela redução significativa dos níveis de GATA3 mediante a inibição da via Notch (com DAPT) nas células tratadas com TNF- $\alpha$ e CHX (Gráfico 18).

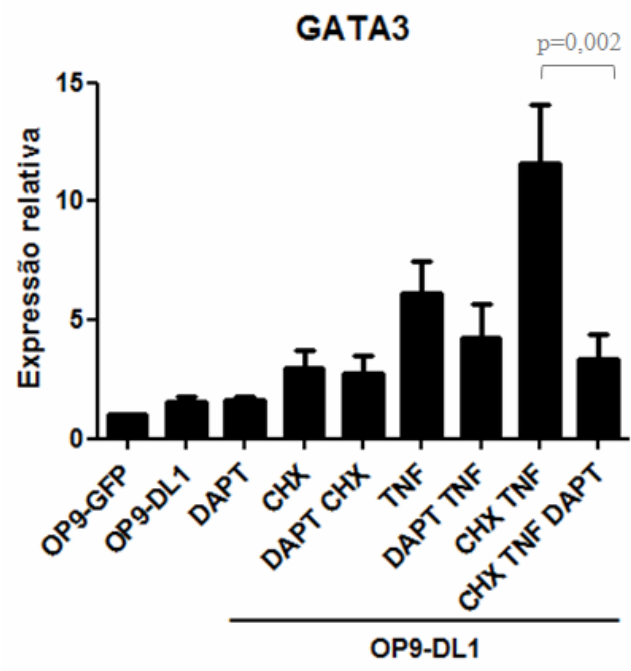

Gráfico 18. A ação conjunta do pré-tratamento com CHX nas CTH, DAPT e TNF- $\alpha$ evidencia que o efeito positivo de TNF- $\alpha$ ocorre de forma dependente da via de sinalização Notch. 


\subsection{Determinação do tempo de cocultivo para análise de outros transcritos de interesse} em sistema de cocultivo das células-tronco hematopoéticas $\mathrm{CD34}^{+}$com as células OP9.

A realização de outro experimento de padronização do tempo de cocultivo foi essencial a fim de avaliarmos os transcritos de interesse propostos nesse trabalho, já que com 12 horas de cocultura, tempo estipulado de acordo com a expressão do transcrito alvo direto de Notch (HEY1), não observamos a transcrição dos demais transcritos propostos.

Nesse experimento, as linhagens celulares OP9-GFP e OP9-DL1 $\left(1_{\mathrm{x}} 10^{4}\right.$ células $)$ foram plaqueadas (placa de 24 poços), após três dias, as $\mathrm{CTH} \mathrm{CD} 34^{+}$isoladas foram colocadas em cocultivo com a monocamada de células estromais e mantidas por diferentes períodos de cultivo (12h, 36h, 60h, 84h, 108h e 132h), experimento realizado em duplicata.

Avaliamos os transcritos de interesse (RUNX1, HOXB4, USF1, NFKB1, NFKB2, RELA e RELB) ao longo do tempo de cocultivo, para verificarmos se há expressão dos mesmos, e estabelecer o melhor período para efetuar as análises. Porém, apenas verificamos ativação da expressão de HOXB4 (Gráfico 19). Esse transcrito apresentou seu pico de transcrição com 36 horas de cocultivo, desta forma, realizamos outros experimentos em triplicata a fim de avaliar seu comportamento em presença das drogas (DAPT, CHX e do TNF- $\alpha$ ).

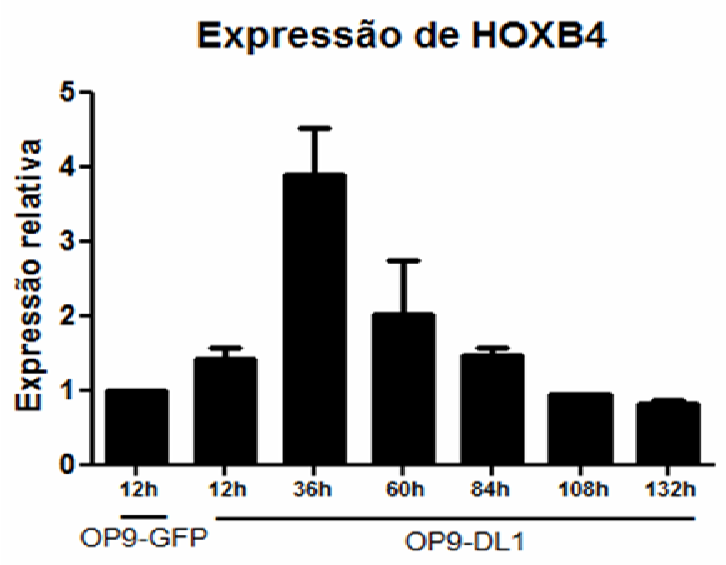

Gráfico 19. Análise da expressão do HOXB4 ao longo do tempo (12h, 36h, 60h, 84h, 108h e 132h) de cocultivo das CTH CD34+ em presença das células de camundongo (OP9-GFP e OP9-DL1). 


\subsubsection{Análise da expressão de HOXB4 com 36 horas de cocultivo.}

Ao analisarmos a expressão de HOXB4 verificamos a dependência da via Notch, isso porque apenas no cocultivo com as células expressantes do ligante DL1 que ocorria transcrição, e em presença de DATP essa era reprimida (Gráfico 20).

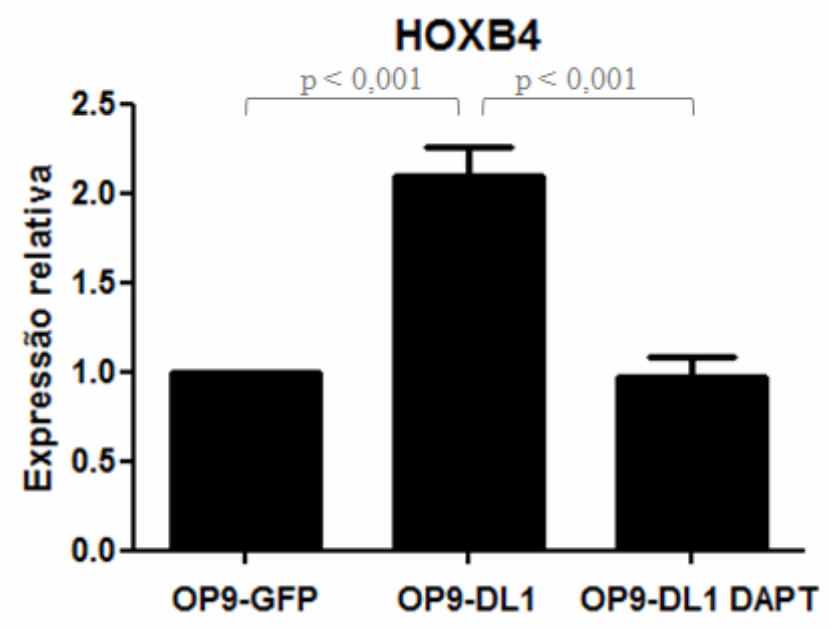

Gráfico 20. A análise da transcrição de HOXB4, através do cocultivo das CTH CD $34^{+}$com as linhagens OP9GFP e OP9-DL1, evidenciou a participação da via de sinalização Notch no controle transcricional desse fator, e este é confirmado pelo uso de DAPT.

Ao avaliarmos a ação de TNF- $\alpha$ sobre a expressão de HOXB4 identificamos um efeito positivo significante sobre a transcrição deste fator que, no entanto, foi completamente eliminado mediante a inibição da via Notch, evidenciando uma ação sobre a mesma (Gráfico 21).

Mediante tratamento com CHX, o efeito positivo de TNF- $\alpha$ sobre a expressão de HOXB4 deixou de ser significativo, evidenciando um efeito indireto de TNF- $\alpha$ dependente da síntese protéica de novo (Gráfico 22). Ao mesmo tempo, na ausência de TNF, a inibição da síntese protéica (pela $\mathrm{CHX)}$ resulta num pequeno aumento na transcrição de HOXB4, indicando um potencial efeito negativo de proteínas sintetizadas de novo. 


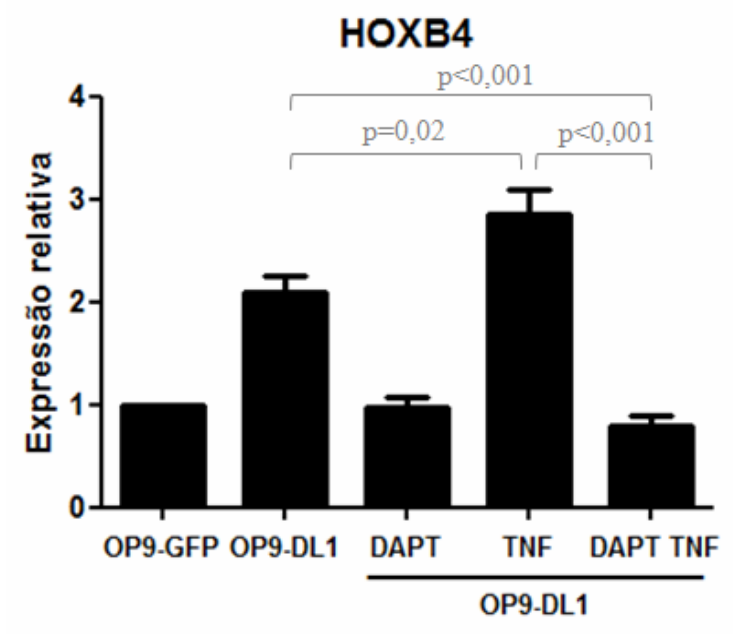

Gráfico 21. Ação positiva do TNF- $\alpha$ sobre a transcrição de HOXB4, de maneira dependente da via Notch, uma vez que em presença da droga DAPT, não observamos aumento na expressão de HOXB4 mesmo em presença de TNF- $\alpha$.

\section{HOXB4}

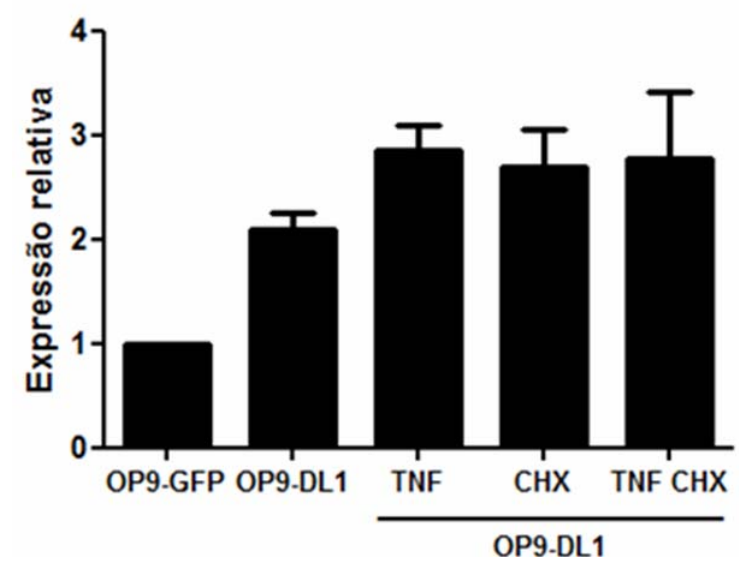

Gráfico 22. A ação positiva do TNF- $\alpha$, ocorre de forma dependente da síntese protéica, pois em presença de CHX o efeito de TNF- $\alpha$ deixa de ser notado.

Interessantemente, mediante inibição da via Notch (na presença de DAPT), o bloqueio da síntese protéica pela CHX leva à indução transcricional de HOXB4 a níveis equiparáveis aos observados mediante a ativação da via Notch (Gráfico 23). Este resultado implica que a regulação transcricional de $\mathrm{HOXB} 4$, mediada pela via Notch, não se daria necessariamente de forma direta, mas de forma indireta, uma vez que a transcrição ocorre mesmo na ausência da ativação da via Notch (Gráfico 23). 


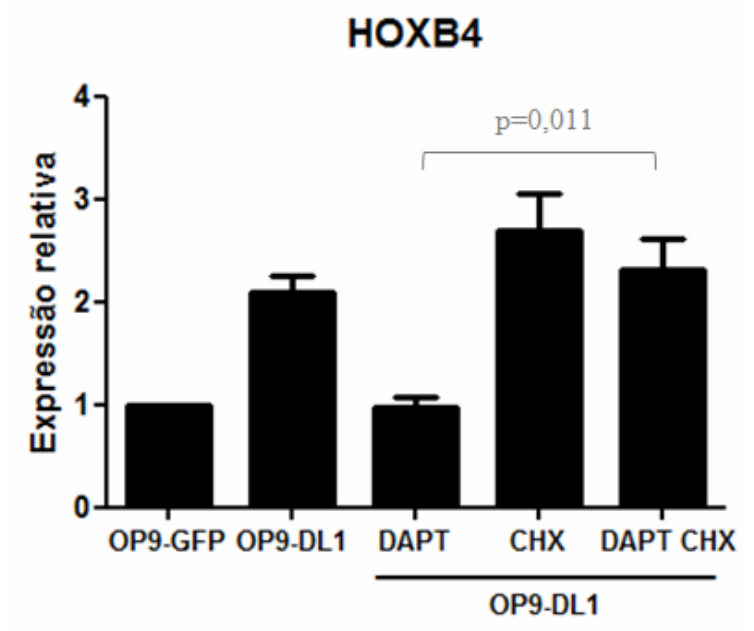

Gráfico 23. A regulação transcricional de HOXB4 é, indiretamente, mediada pela via Notch, pela ligação do complexo NICD/CSL à região promotora de HOXB4.

\subsubsection{Considerações sobre os demais transcritos}

Dentre os demais transcritos avaliados neste trabalho (RELB, RELA, NFKB1, NFKB2, USF1, RUNX1), nenhum teve sua expressão induzida pela ativação da via Notch, durante as 12 horas do cocultivo com as OP9-DL1.

Em presença de TNF- $\alpha$, houve aumento significativo $(\mathrm{p} \leq 0,05)$ nos níveis transcricionais de RELA ( $\mathrm{p}=0,12)$, RELB, NFKB1 e NFKB2, enquanto que os transcritos USF1 e RUNX1 não apresentaram diferenças significativas no nível de expressão independente do tratamento empregado.

Além disso, podemos verificar para os transcritos NFKB1 e NFKB2 que as CTH $\mathrm{CD}^{+} 4^{+}$pré-tratadas com $\mathrm{CHX}$ apresentaram níveis transcricionais ainda maiores em presença de TNF- $\alpha$, se comparadas às células não tratadas, o que evidencia, que alguma(s) proteína(s) sintetizada(s) pelas $\mathrm{CTH} \mathrm{CD} 34^{+}$atua de forma negativa sobre a expressão desses transcritos. Interessantemente, na presença de TNF e CHX, a inibição da via Notch (por DAPT) resulta numa redução perceptível no nível transcricional de NFKB1 $(p=0,13 ; n=2)$ e de NFKB2 $(\mathrm{p}=0,21 ; \mathrm{n}=2)$ (Gráfico 24). Um comportamento similar foi observado para RELA e RELB, no entanto, de forma menos evidente. Finalmente, nas CTH em cocultivo com as células OP9- 
DL1, com a inibição da síntese protéica, e na ausência de TNF, observamos um aumento nos níveis transcricionais de NFKB1 $(p=0,053)$ e RELA $(p=0,107)$, apesar desta comparação ser feita com CTH em cocultivo com células OP9-GFP sem CHX.

NFKB1

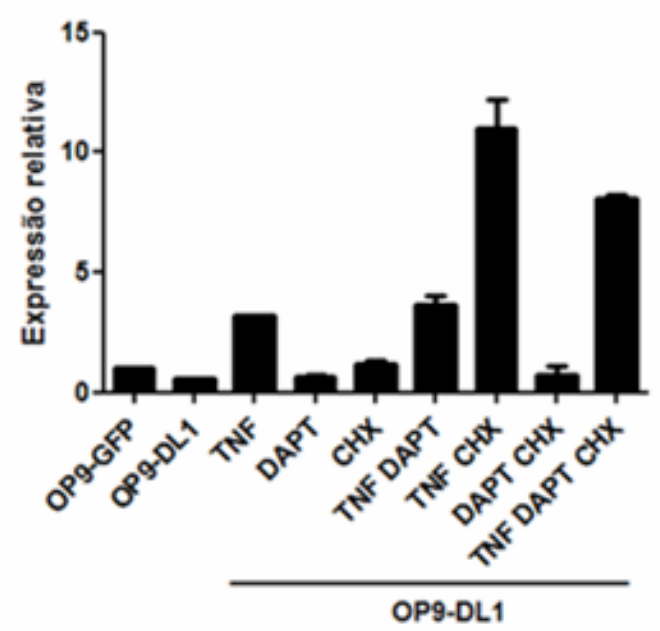

RELA

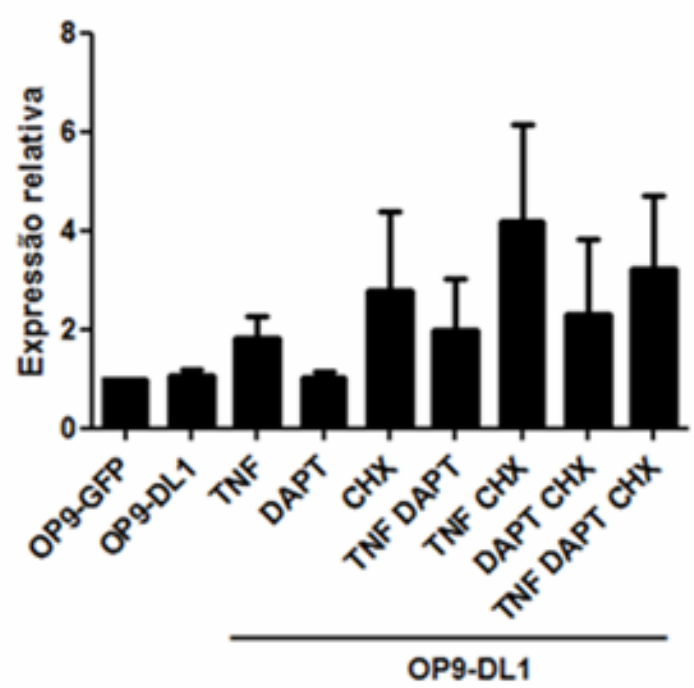

NFKB2

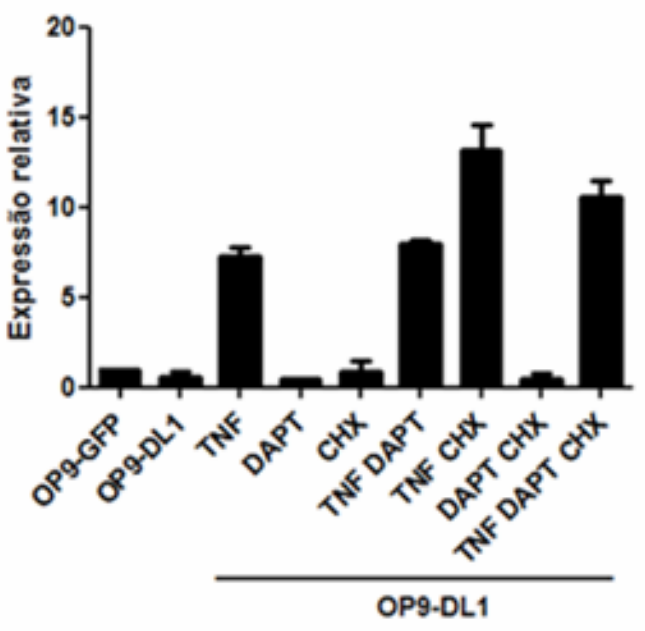

RELB

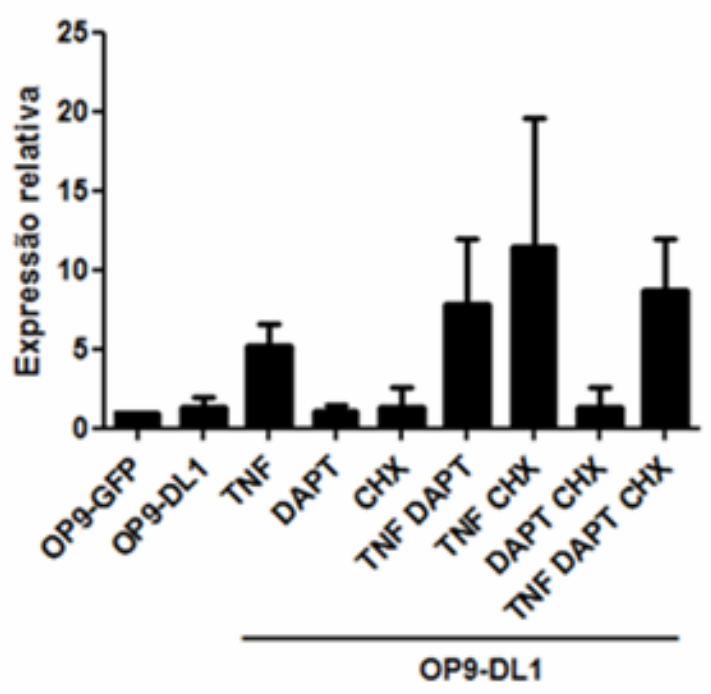

Gráfico 24. Análise de expressão de RELA, RELB, NFKB1 e NFKB2 em CTH CD34+ pré-tratadas ou não com CHX, cocultivadas com células estromais de camundongos OP9-GFP e OP9-DL1, em presença ou ausência de DAPT e TNF- $\alpha$, e em presença simultânea dos mesmos. 
5. DISCUSSÃO 
No presente trabalho, nós avaliamos o papel desempenhado pela via Notch no controle

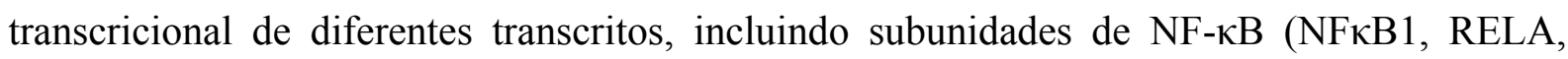
NFkB2 e RELB), bem como outros fatores transcricionais envolvidos com a biologia de células-tronco e com o processo de diferenciação linfocítica (HEY1, HES1, RUNX1, GATA3, USF1 e HOXB4). Ainda, o efeito de TNF- $\alpha$ (um agonista da via NF- $\kappa$ B) sobre a transcrição, também foi avaliado.

Nossos resultados confirmam um efeito direto da ativação de Notch sobre a expressão de HEY1, HES1 e GATA3 e revelam pela primeira vez, a regulação transcricional de HOXB4 pela via Notch, estabelecendo uma ligação direta entre o papel proposto para esta via, na autorenovação e proliferação de progenitores hematopoéticos, com o papel estabelecido de HOXB4 nestes processos. Ainda, observamos que o TNF- $\alpha$ atua de forma positiva sobre a expressão desses fatores transcricionais (com exceção de HES1; Figura 14) e que o bloqueio da síntese protéica nas $\mathrm{CTH}$, pela $\mathrm{CHX}$, tem efeito positivo sobre a expressão de HES1, GATA3 e HOXB4; enquanto tem efeito negativo sobre HEY1(Figura 15). 


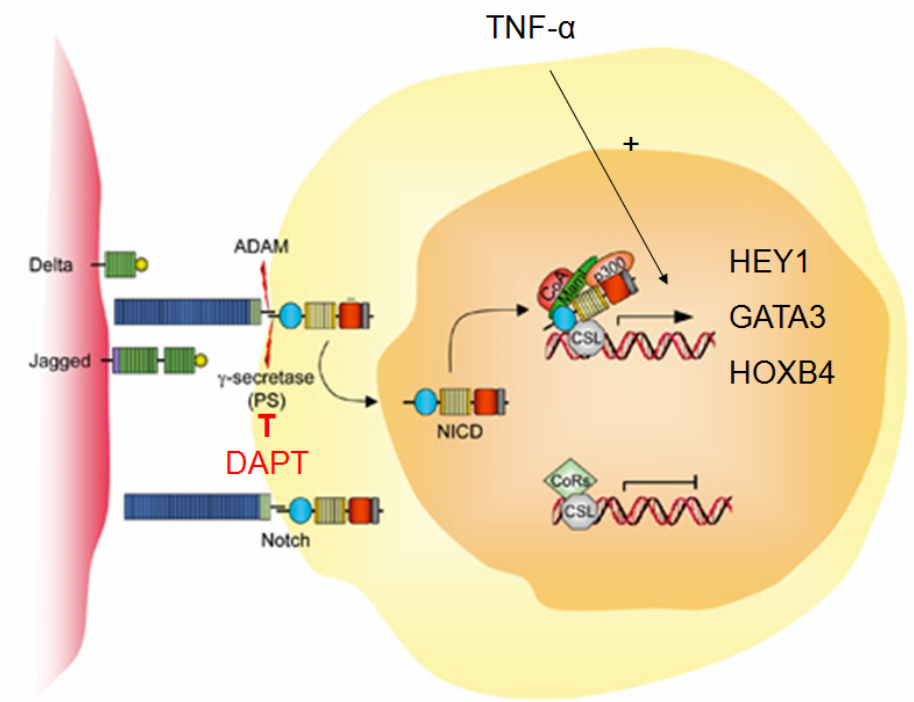

Figura 14. Dependência da via de sinalização Notch para diferentes fatores transcricionais (HEY1, HES1, GATA3 e HOXB4), evidenciado pela maior taxa de expressão desses transcritos quando em presença do ligante de Notch, Delta-like 1, e, confirmado pela repressão desses fatores em presença de DAPT (droga inibitória da via de sinalização Notch), com exceção de GATA3, o qual não é reprimido em presença do inibidor. Além do papel positivo desempenhado pela citocina TNF- $\alpha$ sobre a transcrição dos fatores HEY1, GATA3 e HOXB4.

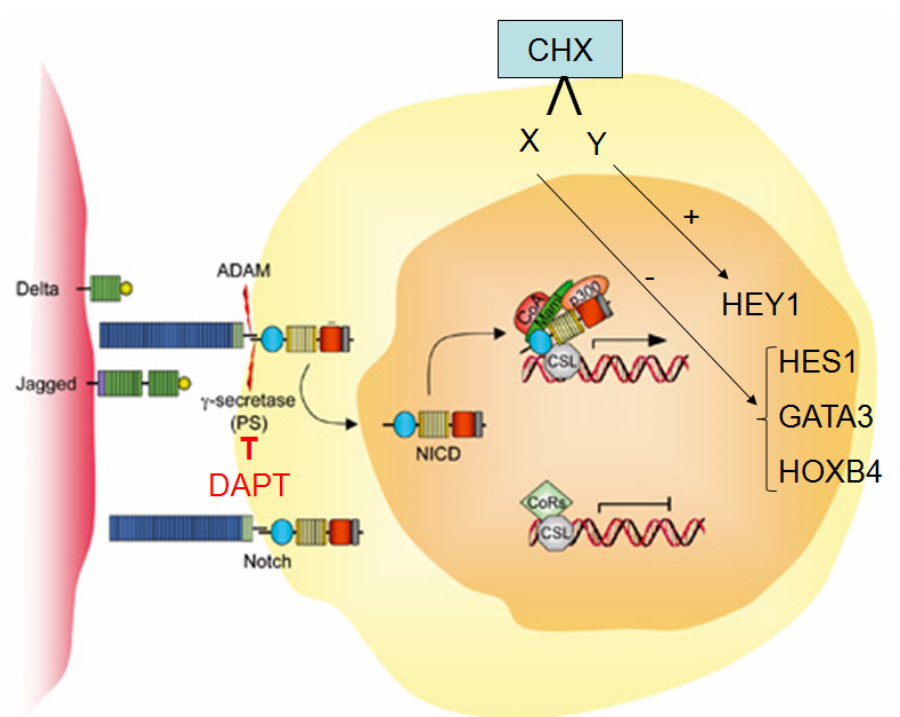

Figura 15. Esquema ilustrativo da dependência da via de sinalização Notch para diferentes fatores transcricionais (HEY1, HES1, GATA3 e HOXB4). Evidenciado pela maior taxa de expressão desses transcritos quando em presença do ligante de Notch, Delta-like 1, e confirmado pela repressão desses fatores em presença de DAPT (droga inibitória da via de sinalização Notch). Além do papel desempenhado pela CHX sobre a transcrição desses fatores, evidenciando que para a maioria dos fatores avaliados há alguma proteína sintetizada pelas $\mathrm{CTH} \mathrm{CD} 34^{+}$, que reprimem sua transcrição. 


\subsection{Papel de Notch e NF-kB na Hematopoese}

Durante o desenvolvimento embrionário, as células-tronco hematopoéticas (CTH) definitivas surgem numa região chamada aorta gônado-mesonefros (AGM), a partir do chamado endotélio hemogênico. Após sua emergência, as CTH migram para órgãos como o fígado e o baço, onde a hematopoese ocorre de forma predominante, durante o período fetal até que, próximo à época do nascimento, as $\mathrm{CTH}$ migram novamente para a medula óssea $(\mathrm{MO})$ onde se dará a hematopoese no período pós-natal (Dzierzak, 1999). As CTH também migram da MO para órgãos linfóides, como o timo, onde se dará a produção de linfócitos T (Spits et al., 2002)

Nestas fases, as CTH devem possuir um maior potencial de auto-renovação e proliferação, de forma a suprir a demanda de progenitores indiferenciados. Estas propriedades intrínsecas destas células-tronco derivam em parte, de sinais extrínsecos presentes nos locais onde elas se encontram. Nestes nichos celulares, fatores solúveis como citocinas, assim como componentes presentes na membrana de outras células ou na matriz extracelular, estabelecem microambientes especializados, dando suporte, tanto à manutenção do pool de células-tronco indiferenciadas, como à diferenciação em linhagens específicas (Schmitt et al., 2006; Mitsiadis et al., 2007).

De maneira geral, atribuem-se à via Notch, importantes papéis na diferenciação e na autorenovação de diferentes tipos de células-tronco (Chiba, 2006). De fato, a ativação de Notch1 promove aumento da auto-renovação das CTH in vivo e favorece a linfopoese (Stier, 2002). A via de sinalização canônica de Notch é indispensável durante a emergência das primeiras CTH definitivas (Kumano et al., 2003) e também tem papel durante a colonização do timo, nas fases inicial de proliferação, promovendo o comprometimento $\mathrm{T}$ linfocítico e contribuindo com a maturação em várias etapas durante o desenvolvimento das células T (Deftos, 2000).

A importância de Notch durante a linfopoiese $\mathrm{T}$ foi observada por Radtke e colaboradores (1999), através de camundongos knockout para Notch1, verificando a redução no tamanho do timo, perda das células $\mathrm{T}$, além de produção excessiva de células B. Outras 
pesquisas que comprovam essa participação essencial, foram realizadas por Jaleco et al., (2001), Schmitt et al., (2002), Hozumi et al., (2004) e Schmitt et al., (2004); esses, através do uso de cultura de linhagens de células estromais de medula óssea em presença do ligante DL1 evidenciaram a produção de células T ao custo do desenvolvimento das células B.

Nestes processos, a via Notch atuaria, coordenando a expressão de outros fatores transcricionais envolvidos na programação responsável pelos mecanismos moleculares ligados às propriedades biológicas específicas destas células, como potencial de proliferação, auto-renovação, e diferenciação.

Assim, entre outros, a família de fatores de transcrição HEY (composta por HEY1, HEY2 e HEYL) e HES podem ser induzidos por Notch (Maier et al., 2000; Iso et al., 2003; Fischer et al., 2007).

O fator transcricional HES1 é uma proteína que pertence à família básica de fatores de transcrição hélice-alça-hélice (bHLH), e atua como repressor da transcrição de genes que requerem uma proteína bHLH para a sua transcrição (Kageyama et al., 2000; Iso et al., 2003; Dudley et al., 2009; Borggrefe et al., 2009, Lee et al., 2009).

HES1 é expresso em timócitos e no estroma, possui papel essencial no desenvolvimento normal das células $\mathrm{T}$, além de regularem a morfogênese dos tecidos, mantendo as células indiferenciadas (Tomita 1999; Deftos et al., 2000 Hoebeke et al., 2006; Fischer et al., 2007; van de Walle et al., 2009; Kageyama et al., 2000). No caso do desenvolvimento de células T, a mutação HES1 leva a defeitos de expansão dos primeiros precursores de células T e, assim, suprime a especificação T (Kageyama et al., 2000). Ainda, camundongos deficientes para o gene HES1 morrem ainda durante a gestação ou logo após o nascimento, e apresentam um bloqueio do desenvolvimento de células $\mathrm{T}$, sem alterar o desenvolvimento das demais linhagens hematopoéticas. (Tomita et al., 1999). 
Outro fator transcricional importante tanto na produção quanto na função das células T é GATA3 (Pai et al., 2003; Ho et al., 2007). Este fator pertence a uma família de proteínas conservadas formada por seis membros, sendo três deles associados a fatores hematopoéticos e, os outros três, a fatores endodermais (Ho et al., 2009). Entre os fatores transcricionais que controlam o sistema hematopoético destaca-se o GATA3 (Fischer et al., 2007; Ho et al., 2009).

O fator transcricional GATA3 é expresso em células do sistema imune e pode ser facilmente detectado em células T maturas ou em desenvolvimento e em células NK (Ho et al., 2009). Ele é requerido para o desenvolvimento inicial de progenitores da linhagem $\mathrm{T}$ e em outros estágios do desenvolvimento dessas células (Rothenberg et al., 2005; Singer et al., 2008; Hosoya et al., 2009, van de Walle et al., 2009). Em células do sistema imune, GATA3 apresenta a função de principal regulador da diferenciação celular T helper 2 (Th2) e, recentemente, vem sendo descrito como participante do comprometimento das células $T$, na $\beta$-seleção e no desenvolvimento de células T CD4 ${ }^{+}$(Singer et al., 2008; Ho et al., 2009). Ainda, camundongos deficientes para este fator apresentam letalidade na fase embrionária, enquanto que, outro experimento realizado com camundongos quiméricos para deficiência no gene GATA3 permitiu apenas a detecção de células $\mathrm{B}$ e NK, mas não de células $\mathrm{T}$, evidenciando a necessidade de GATA3 para o desenvolvimento de células T (Ting et al., 1996).

Apesar da ativação da via Notch em CTH adultas, promover a auto-renovação e a manutenção do fenótipo indiferenciado, em condições fisiológicas, esta via não tem importância aparente na manutenção da auto-renovação das CTH após sua geração (Duncan, 2005). De acordo com as idéias correntes, tanto a via Notch como a via Wnt/B-catenina atuariam na manutenção de um fenótipo indiferenciado e a proliferação/auto-renovação das CTH; no entanto, controvérsias existem quanto aos mecanismos de interação entre estas vias, bem como os responsáveis por seus papéis (Reya, 2003; Duncan, 2005; Weerkamp, 2006; Stall, 2010). 
Dentre as funções atribuídas à via Wnt, estaria o controle transcricional de um fator de transcrição com importante função nas CTH primitivas, HOXB4 (Buske et al., 2002). O fator de transcrição HOXB4 faz parte da família dos genes homeobox (HOX), os quais regulam o desenvolvimento e a homeostase tecidual pós-natal (Giannola et al., 2000). Na fisiologia das células-tronco hematopoéticas, os genes Hox mantêm uma crítica relação das células-tronco para diferenciação específica em células sanguíneas ao longo da vida. Além disso, diversos estudos demonstram que a expressão dos genes HOX varia com a diferenciação das célulastronco (Giannola et al., 2000). O fator HOXB4 tem abundante expressão nas células hematopoéticas primitivas e sua expressão declina com a especificação durante o processo de diferenciação celular, isso ocorre porque o HOXB4 tem papel na regulação do balanço entre a auto-renovação e a diferenciação das células-tronco hematopoéticas, sendo responsável, principalmente, pela manutenção do fenótipo das células-tronco primitivas (Sauvageau et al., 1994; Giampaolo et al., 1994; Moretti et al., 1994; Giannola et al., 2000; Pineault et al., 2002; Haddad et al., 2008; Milson, 2009). Ainda, genes HOX apresentam funções no desenvolvimento dos linfócitos T normais, e na ativação de NK (Lawrence et al., 1996). Devido a esse papel fundamental na hematopoese, anormalidades no gene Hox levam a anormalidades de múltiplas linhagens de células hematopoéticas (Tsiftsoglou et al., 2009).

\subsection{Fatores de Transcrição}

\subsubsection{RELA, RELB, NFKB1 e NFKB2}

Os genes das diferentes subunidades que compõe os complexos transcricionais da família NF-кB (RelA, RelB, NF-KB1 e NF-KB2) possuem, em seus promotores, seqüências específicas para a ligação de complexos NF-אB (Panepucci et al., 2010) e consequentemente, 
constituem potenciais alvos diretos desta via (Liptay et al., 1994; Lombardi et al., 1995; Bren et al., 2001).

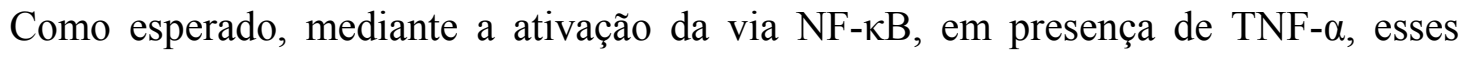
fatores têm seu nível transcricional elevado. Ainda, o pré-tratamento das células-tronco com a droga CHX implicou em um aumento ainda maior do nível de expressão, evidenciando um mecanismo de feedback negativo, mediado por proteínas sintetizadas pelas células CD34 ${ }^{+}$ durante o cocultivo; em linha com a indução de alvos transcricionais diretos de NF-kB, que codificam proteínas, como TNFAIP/A20 e IkB $\alpha$, que modulam a atividade dessa via (Werner et al., 2008).

Apesar da regulação desses fatores pela via de sinalização Notch não ter sido evidenciado na ausência de estímulos complementares, certa dependência da via de sinalização Notch pode ser inferida pela redução nos níveis transcricionais, observados na presença de TNF- $\alpha$ e com a inibição da síntese protéica pela CHX, mediante a inibição da via Notch pela droga DAPT, principalmente para NFKB1 e NFKB2. Em linha com o potencial papel de Notch na regulação destes fatores, Vilimas e colaboradores (2007) identificaram a indução transcricional direta de NFKB2 e RELB, pelo domínio intracelular de Notch1 (NICD) e, ainda, identificaram a ligação do NICD ao complexo IKK, com o aumento da atividade de fosforilação de $\operatorname{IkB} \alpha$ (com sua conseqüente degradação e de-repressão do complexo NF-kB). Nossos resultados corroboram este mecanismo e estão em linha com a observação inicial feita anteriormente por nosso grupo, da presença de sítios de ligação de CSL (parceiro do NICD na ativação transcricional) nos promotores de todas as subunidades

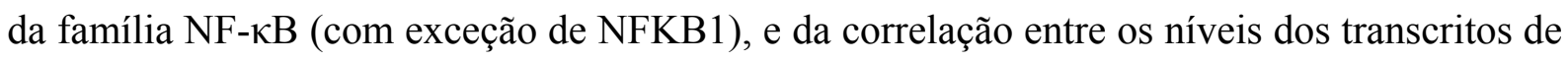
Notch1 e NFKB2 e RELB (Panepucci et al., 2010). 


\subsubsection{HES1}

Nossos resultados evidenciam a dependência da via Notch para a expressão HES1, de acordo com a literatura (Tomita 1999; Kageyama et al., 2000; Hoebeke, 2006; Challen et al., 2010).

Os resultados obtidos por nós indicam que em presença de TNF- $\alpha$ (na concentração de 0,25ng/ml), a expressão de HES1 apresenta uma variação maior, sofrendo aparentemente, um efeito negativo, porém, o efeito deste fator não fica claro. A literatura também mostra resultados divergentes; Johnston e colaboradores (2009) verificaram que o HES1 tem expressão reduzida em presença de TNF- $\alpha$, enquanto, outros (Aguilera et al., 2004; Espinosa et al., 2002) mostram um efeito positivo de TNF- $\alpha$ sobre a expressão de HES1. No modelo proposto por Aguilera e Espinosa, em condições sem estímulo, o inibidor da via NF-kB IkB $\alpha$ ligaria e recrutaria repressores transcricionais, como N-CoRs e HDACs, se associando a seqüências regulatórias de alvos transcricionais de Notch (como HES1), inibindo sua transcrição; em resposta ao $\mathrm{TNF}-\alpha$, as kinases IKKs atuariam sobre $\mathrm{IkB} \alpha$, causando a liberação do complexo N-CoRs e HDACs, o que resultaria na acetilação do promotor HES1 e no aumento da ativação transcricional desse gene. Ao contrário de nosso estudo, no entanto, os estudos acima foram feitos utilizando fibroblastos, alem de utilizarem uma concentração de TNF- $\alpha 10$ vezes maior $(25 \mathrm{ng} / \mathrm{ml})$ e avaliarem o efeito nos minutos iniciais após a adição de TNF- $\alpha$. Portanto, as diferenças observadas podem estar ligadas ao comportamento oscilatório da resposta transcricional da via NF-kB, mediado pelo feedback negativo das proteínas IkB $\alpha$ sintetizadas tardiamente. 

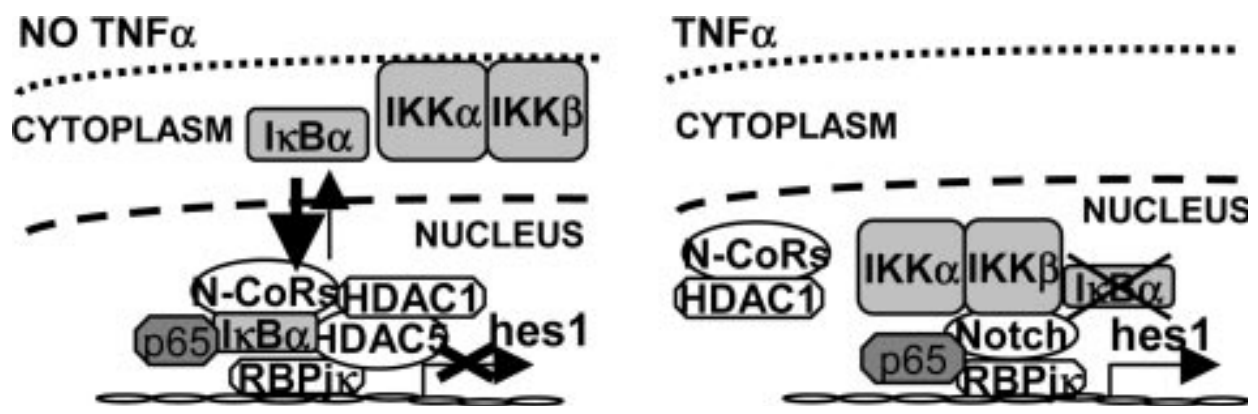

Figura 16. O modelo indica que as proteínas $\operatorname{IkB} \alpha$ são recrutadas pelo promotor de HES1, juntamente com elementos repressores, levando a repressão de sua transcrição. E que em presença de TNF- $\alpha$, há liberação do sistema, pois as IKKs são recrutadas para o promotor, resultando em liberação das IkBa, e, consequentemente, causando a ativação transcricional desse gene

Em relação ao tratamento com a droga $\mathrm{CHX}$ verificamos que esta promove aumento da taxa transcricional de HES1, e isso é coerente com a literatura (Kuroda et al., 1999; Schawanbeck 2008). O aumento transcricional promovido pelo uso da CHX estaria em linha com o feedback negativo resultante da expressão tardia das proteínas $\mathrm{IkB} \alpha$ (Schawanbeck, 2008; Chadwick et al., 2009). Esse mecanismo de feedback na regulação de HES1 implicaria na oscilação de sua expressão, o que também pode ser observado em nossos experimentos (variação do nível de transcrição) (Hirata et al., 2002; Fischer et al., 2007; Song et al., 2008; Chadwick et al., 2009; Kobayashi et al, 2010).

\subsubsection{HEY1}

De acordo com os nossos resultados, podemos notar que a regulação de HEY1 é, de fato, diretamente relacionada com a via de Notch, concordante com os dados de Curry e colaboradores (2006). Entretanto, contrastando com a regulação de HES1, o bloqueio da síntese protéica pelo pré-tratamento das CTH com cycloheximide resulta numa menor indução transcricional de HEY1, no cocultivo com as células OP9-DL1, indicando um efeito positivo de proteínas sintetizadas de novo. Além disso, TNF- $\alpha$ exerce um efeito positivo sobre a transcrição de HEY1, mesmo na presença de DAPT (e, portanto, de forma independente da via Notch), no entanto, este aumento não ocorre com a inibição da síntese protéica pela CHX 
(e, portanto, é dependente de proteínas sintetizadas de novo). Assim, a regulação transcricional de HEY1 pelo TNF- $\alpha$ não estaria ligada à modulação negativa de proteínas $\mathrm{IkB} \alpha$, sobre o complexo NICD/CSL, ao contrario do modelo proposto para HES1 (Aguilera et al., 2004; Espinosa et al., 2002).

\subsubsection{GATA3}

De acordo com trabalhos já publicados, a expressão de GATA3 sofre aumento ao longo do processo de diferenciação dos linfócitos T (Chari et al., 2008; Ho et al., 2009).

Resultados obtidos anteriormente por nosso grupo; entre eles, a alta correlação entre os níveis transcricionais de NOTCH1 e GATA3 e a presença de sítios de ligação para CSL no promotor da isoforma GATA3a indicavam a possível regulação de GATA3 pela via Notch (Panepucci et al., 2010). Resultados obtidos por outros grupos identificaram a regulação direta da isoforma GATA3a pelo complexo transcricional CSL/NICD, no entanto, durante a diferenciação de linfócitos T naive em linfócitos Th2 (Amsen et al., 2007; Fang et al., 2007; Kubo, 2007; Ho et al., 2009). Nossos resultados evidenciam que a transcrição de GATA3 é dependente da via de sinalização Notch, também em CTH, e de forma direta. Interessantemente, a dependência da via Notch (verificada pelo efeito negativo da droga DAPT sobre a indução transcricional) só ficou evidenciada na presença concomitante do estimulo proporcionado pelo TNF- $\alpha$, tornando-se estatisticamente significativa na presença adicional da CHX. Nestas condições, a indução transcricional proporcionada pelo TNF- $\alpha$ é completamente eliminada com a inibição da via Notch (CHX vs CHX TNF vs CHX TNF DAPT, gráficos 17 e 18), evidenciando que o TNF- $\alpha$ atua diretamente sobre a via Notch (por mecanismos que independem da síntese protéica de novo), modulando positivamente a transcrição de GATA3. 
Interessantemente, GATA3 apresenta uma transcrição basal aumentada no cocultivo com a linhagem OP9-DL1 (cerca de 1,5 x, em comparação às OP9), que não depende da via Notch (mantendo-se na presença de DAPT). Esta expressão basal independente da via Notch é elevada com o bloqueio da síntese protéica pela $\mathrm{CHX}$ (cerca de $3 \mathrm{x}$, em comparação às OP9) indicando o papel negativo de proteínas constitutivamente expressas nas $\mathrm{CTH}$. Ainda, comparado ao observado nas CTH cocultivadas com a linhagem OP9, o TNF- $\alpha$ causa um aumento nos níveis de GATA3, de cerca de 6x nas CTH sem a inibição da via Notch, e de cerca de $4 \mathrm{x}$ com a inibição desta via por DAPT. Estes resultados indicam que TNF- $\alpha$ poderia regular os níveis basais de GATA3 na ausência de sinalização da via Notch e, ainda, modular a transcrição induzida pela ativação desta via. O mecanismo proposto acima, explicaria os resultados obtidos por Smits e colaboradores, que relataram a indução transcricional de GATA3 em CTH mediante o tratamento com TNF- $\alpha(10 \mathrm{ng} / \mathrm{ml})$ durante 60 horas, sem, no entanto, encontrar variações nos níveis transcricionais de receptores Notch ou do alvo HES1 (Smits et al., 2007).

Nossos resultados, quando confrontados com outros obtidos utilizando o mesmo sistema de cocultivo, apresentam algumas diferenças relevantes. Enquanto Awong e colaboradores (2009) identificaram um aumento na expressão de GATA3 de 6x somente no sexto dia de cocultivo (aumentando gradativamente até 10x no $14^{\circ}$ dia avaliado), na presença de TNF- $\alpha$ na reduzida concentração utilizada por nós, esta indução já pode ser observada com apenas 12 horas de cocultivo. Em outro estudo, feito por Van de Walle e colaboradores (2009), a expressão de GATA3 não apresentou variação significativa após 40 horas de cocultivo com a linhagem OP9-DL1 e tampouco variou com diferentes concentrações do inibidor da via Notch (GSI), provavelmente devido ao curto período avaliado e à ausência do co-estímulo do TNF- $\alpha$. 


\subsubsection{HOXB4}

Em estudos prévios deste grupo, uma alta correlação entre os níveis transcricionais dos fatores de transcrição HOXB4 e USF1 foi identificada, o que indicaria uma possível regulação de HOXB4 por USF1 (Panepucci et al., 2010). De fato, a literatura indicava que a expressão de HOXB4 pode ser regulada nas CTH, por um complexo formado pelos fatores transcricionais USF1/2 e NF-Y (Giannola et al., 2000; Zhu et al., 2003). No entanto, a alta correlação observada entre os níveis transcricionais dos fatores de transcrição HOXB4 e NOTCH1, nos levaram a explorar a uma possível regulação de HOXB4 por Notch1.

Nossos resultados demonstram que, de fato, a transcrição de HOXB4 é induzida pela ativação da via Notch (nos cocultivos com OP9-DL1) e que a inibição por DAPT impede esta indução; no entanto, mediante o bloqueio da síntese protéica pela $\mathrm{CHX}$, a inibição da via Notch por DAPT não impede a transcrição de HOXB4, que ocorre a níveis equiparáveis aos observados mediante a ativação da via Notch (Gráfico 23). Estes resultados implicam que a regulação transcricional de HOXB4 (mediada pela via Notch) não se daria necessariamente de forma direta, pela ligação do complexo NICD/CSL à região promotora de HOXB4 (e sua conseqüente ativação transcricional), mas, de forma indireta, uma vez que a transcrição ocorre mesmo na ausência da ativação da via Notch.

Em um modelo compatível com os resultados observados por nós, outro fator transcricional seria responsável pela transcrição de HOXB4. Ainda, este fator estaria presente na $\mathrm{CTH}$, sendo mantido num estado latente pela ação de uma proteína inibitória expressa constitutivamente e provavelmente com um rápido turnover. Assim, o bloqueio da síntese protéica levaria à redução nos níveis da suposta proteína inibitória, liberando a transcrição de HOXB4. Neste modelo, a regulação "Notch-dependente" poderia ser explicada por um mecanismo indireto envolvendo o controle da proteína inibitória. Assim, com a ativação da via Notch, o complexo NICD/CSL poderia bloquear a transcrição da própria proteína 
inibitória, ou ainda, ativar a transcrição de uma proteína responsável pelo seqüestro da proteína inibitória, ou ainda, ativar a transcrição de um microRNA que controlasse a tradução da mesma. Em qualquer um dos mecanismos, a ativação da via Notch teria como conseqüência, a redução nos níveis da suposta proteína inibitória, liberando a transcrição de HOXB4. Inversamente, com a inibição da via Notch (por DAPT) esta regulação não ocorreria e a proteína inibitória continuaria sendo produzida. Em linha com nossos resultados, o bloqueio da síntese protéica pela $\mathrm{CHX}$ teria um efeito equivalente à ativação de algum destes mecanismos pela via Notch, explicando a transcrição de HOXB4, mesmo na presença de DAPT.

O controle transcricional indireto pela via Notch, como o proposto acima, seria compatível com a cinética retardada observada na expressão de HOXB4 ao longo do período avaliado, com a ativação mais tardia (com pico em 36h, gráfico 17), em comparação com a indução precoce de alvos diretos do complexo CSL/NICD, como HES1 e HEY1.

Além do complexo formado pelos fatores transcricionais USF1/2 e NF-Y (Giannola et al., 2000; Zhu et al., 2003), outro candidato ao controle transcricional de HOXB4 seria a $\beta$ catenina (Reya et al., 2003). No entanto, a ativação transcricional pela via canônica Wnt/ $\beta$ catenina, resulta da inibição da proteína GSK3$\beta$ (após a ligação de fatores Wnt solúveis a receptores Frizzled), que deixa de induzir a degradação da $\beta$-catenina (por sua fosforilação), levando ao seu acúmulo e translocação para o núcleo, onde se liga ao complexo TCF-LEF ativando a transcrição (Katoh \& Katoh, 2007; Mikels \& Nusse, 2006; Reya \& Clevers, 2005). No entanto, este mecanismo implicaria a necessidade de síntese protéica da $\beta$-catenina para a ativação transcricional de HOXB4, o que não se encaixa com a indução mediante o bloqueio da síntese nas CTH pela CHX. 


\subsubsection{USF1}

Como mencionado acima, o fator USF1 poderia ser o responsável pela ativação transcricional de HOXB4, resultante da ativação da via Notch nas CTH (Zhu et al., 2003; Giannola et al., 2000). Os fatores de transcrição da família USF têm sido descritos como participantes da regulação gênica, da resposta imune, do ciclo celular e do controle da proliferação (Corre et al., 2005).

Como não observamos diferenças significativas na expressão deste fator mediante a ativação da via Notch, na presença ou ausência de TNF, concluímos que nas condições avaliadas, o controle da expressão de HOXB4, não se daria por variações nos níveis de USF1. Assim, se o controle transcricional de HOXB4, mediante a ativação da via Notch, se deva ao complexo contendo USF1, este controle deve ocorrer pela modulação direta de sua atividade transcricional (pelo controle da proteína inibitória), e não pela síntese secundária deste fator levando ao aumento de seus níveis. No entanto, isto não exclui a possibilidade de que em condições basais de $\mathrm{CTH}$ presentes na $\mathrm{MO}$ ou no SCU, como nas avaliadas anteriormente por este grupo (Panepucci, 2010), os níveis de USF1 possam ser responsáveis pelos níveis elevados de HOXB4.

\subsubsection{RUNX1}

O fator transcricional RUNX1, também conhecido por AML1 (leucemia mieloide aguda 1), é essencial para a regulação da hematopoese, participando na formação, proliferação e quiescência das CTH (Friedman 2009), além de apresentar papel na diferenciação e função de linfócitos T (Egawa et al., 2007; Ono et al., 2007; Hu et al., 2007). Os fatores da família RUNX são expressos no timo e possuem atividade durante o desenvolvimento de células $\mathrm{T}$ (Rothenberg et al., 2005) e camundongos deficientes em RUNX1 possuem reduzido número de progenitores linfóides, e desenvolvimento anormal de células T (Friedman 2009). 
Apesar da ligação entre as vias Notch e o fator Runx1 em CPH, identificada pela ativação da via de sinalização Notch, mediante a superexpressão de RUNX1 (Challen et al.,

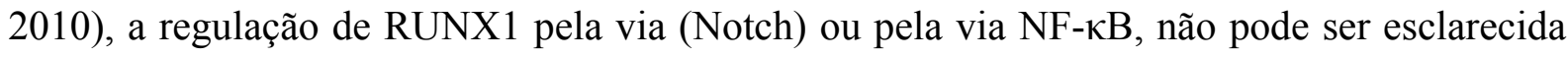
através do presente trabalho, uma vez que não houve variação de transcrição de RUNX1 entre o cocultivo realizado com as células OP9-GFP e OP9-DL1, isoladamente ou em presença de outros tratamentos. De acordo com Chari e colaboradores (2008) uma elevada expressão de RUNX1 é verificada em linfócitos duplo positivos $\mathrm{CD}^{+} \mathrm{CD} 8^{+}$, enquanto que nos duplo negativos, a expressão deste fator transcricional é bastante reduzida. Em nosso trabalho como avaliamos nas primeiras horas do processo de diferenciação celular, não possuíamos células duplo positivas, mas somente duplo negativas, em linha com os resultados de Chari.

\subsection{Diferenciação Celular}

De acordo com Jaleco e colaboradores (2001), células precursoras hematopoéticas cultivadas com o ligante de Notch (DL1), apresentam um bloqueio completo da diferenciação em linhagens de células B, às custas da promoção de populações celulares com características de precursores de células T e NK.

$\mathrm{O}$ processo de diferenciação celular linfocítica $\mathrm{T}$, a partir das células-tronco hematopoéticas $\mathrm{CD}^{+} 4^{+}$, não depende apenas da via de sinalização Notch, mas também das citocinas IL-7 e Flt3-L. Assim, neste trabalho, bem como nos demais trabalhos da literatura utilizando este sistema de cocultivo, as citocinas IL-7 e Flt3-L foram utilizadas, tanto nos cocultivos com a linhagem OP9-DL1, como nos cocultivos controle com a linhagem OP9GFP. Estas citocinas têm papel tanto na proliferação quanto na diferenciação celular. A IL-7 é um fator de crescimento, responsável pela proliferação, sobrevivência, diferenciação e desenvolvimento de células T, enquanto que a Flt3-L é um fator de crescimento, que ocasiona a proliferação, sem afetar a diferenciação celular (Wang, 2006c). 
Nossos resultados, em relação ao processo de diferenciação celular, corroboraram com as informações já descritas na literatura. As CTH CD34 $4^{+}$passaram a expressar o marcador CD7 já com 12 dias de cocultura com as células estromais OP9-DL1 (células transduzidas com o ligante de Notch, Delta-like1). A expressão desse marcador, como é o esperado, aumenta com o tempo de cocultivo. Além disso, ocorre o aparecimento do marcador CD1a, que surge em grande proporção com 21 dias de cocultura com as OP9-DL1.

De acordo com Awong et al. (2009) e La Motte-Mohs et al. (2005) a expressão de CD7 é considerada como o primeiro marcador de superfície que aparece no inicio da linfopoiese $\mathrm{T}$, e que a transição de $\mathrm{CD} 34^{+} \mathrm{CD} 7^{+} \mathrm{CD} 1 \mathrm{a}^{-}$para $\mathrm{CD} 34^{+} \mathrm{CD} 7^{+} \mathrm{CD} 1 \mathrm{a}^{+}$para timócitos iniciais é associado com o comprometimento para células T. A única diferença entre esses trabalhos e o nosso é que o surgimento dos marcadores, tanto do $\mathrm{CD}^{+}$quanto do $\mathrm{CD} 1 \mathrm{a}^{+}$ ocorre anteriormente ao nosso.

No trabalho realizado por La Motte-Mohs e colaboradores (2005) observam o aparecimento de CD7 apenas com 8 dias de cocultura, enquanto que o aparecimento de CD1a ocorreu em torno do $12^{\circ}$ dia, período no qual há mais de $60 \%$ de células CD7, e apenas uma pequena quantidade dessas apresenta o marcador do comprometimento celular (CD1a), menos de $10 \%$, isso em cocultivo das $\mathrm{CTH} \mathrm{CD}^{+} 4^{+} \mathrm{CD} 38^{-}$com as OP9-DL1, enquanto, que o cocultivo com as OP9-GFP gera um pequeno número de células CD7 (não ultrapassando $30 \%$ ) e de CD1a (não ultrapassando 10\%), o que também ocorreu em nosso trabalho. A porcentagem máxima de CD7 ocorreu com 52 dias, porém, este já era bastante grande desde o $16^{\circ}$ dias. Enquanto que em relação a CD1a apenas após $36^{\circ}$ dias de cocultivo mais de $50 \%$ das células passam a expressá-los, o que indica os mesmos padrões de expressão encontrados em nosso estudo, evidenciando que o surgimento do marcador CD1a ocorre quando grande porcentagem das células já expressam o CD7, considerado como marcador comum para análise temporal da diferenciação de células T (Bloom et al., 2006). 
Awong e colaboradores (2009) mostraram que em cocultivo das células murinas OP9DL1 com as CTH CD34 $4^{+} \mathrm{CD} 38^{-/ 10}$ leva ao aparecimento do marcador $\mathrm{CD}^{+}$já no quarto dia de cocultivo, que a porcentagem de células $\mathrm{CD}^{+}$aumenta rapidamente ao longo do tempo de cocultivo, e que o aparecimento de células $\mathrm{CD} \mathrm{a}^{+}$começaram a ser detectadas com 10 dias, e correspondem a apenas $15 \%$ das células $\mathrm{CD}^{+}$. Observam ainda, que as $\mathrm{CD} \mathrm{a}^{+}$chegam a atingir $90 \%$ das células $\mathrm{CD}^{+}$, mas isso apenas no $48^{\circ}$ dias de cocultivo.

Podemos extrapolar nossos resultados, e afirmar que se mantivéssemos o cocultivo por mais tempo observaríamos, provavelmente, o surgimento de células $\mathrm{CD}^{+}$e $\mathrm{CD} 8^{+}$, ou seja, de linfócitos maduros como nos experimentos realizados por Awong (2009) e La Motte-Mohs (2005). A grande maioria dos trabalhos publicados avaliam a expressão desses dois marcadores já no $24^{\circ}$ dia de cocultura, porém isso não foi possível em nosso trabalho, já que partimos de uma população de células-tronco hematopoéticas mais heterogênea $\left(\mathrm{CD} 34^{+}\right)$ quando comparadas as células empregadas nos demais trabalhos, isso porque eles utilizam sorting para isolar as $\mathrm{CTH} \mathrm{CD} 34^{+} \mathrm{CD} 38^{-}$, e essa população por não possuir grande quantidade de progenitores mielóides apresenta cinco vezes mais potencial para originar células $\mathrm{T}$ (Martin et al., 2008; Plum 2008; Awong et al., 2009; La Motte-Moths et al., 2005).

Visando estabelecer o efeito do pré-tratamento das CTH, por 12 horas, com TNF- $\alpha$ na concentração utilizada neste trabalho $(0,25 \mathrm{ng} / \mathrm{ml})$, avaliamos o possível efeito sobre a diferenciação T linfocítica utilizando os mesmos marcadores descritos acima, no entanto, não houve diferenças significativas no período de tempo observado para as populações avaliadas (Gráfico 2). A concentração de $0,25 \mathrm{ng} / \mathrm{ml}$ de TNF- $\alpha$ foi escolhida visando avaliar o efeito deste fator em condições mais próximas às fisiológicas, uma vez que os efeitos biológicos deste fator, em condições não patológicas, ocorrem em concentrações abaixo de cerca de 1ng/ml (Tartaglia , 1993; Corredor, 2002). O efeito do TNF- $\alpha$ sobre a linfopoese, descrito em outros trabalhos, não podem ser diretamente comparados ao nosso. A exemplo, os resultados 
obtidos por Smits e colaboradores, relataram o aumento de linfócitos duplo-positivos em culturas FTOC, a partir de CTH CD34+CD38-, e mediante um pré-tratamento com TNF- $\alpha$ $(10 \mathrm{ng} / \mathrm{ml})$ durante 60 horas (Smits et al., 2007). No entanto, neste mesmo trabalho, o pretratamento por 12 horas, com uma concentração de $1 \mathrm{ng} / \mathrm{ml}$ de TNF- $\alpha$, foi suficiente para evidenciar um efeito positivo sobre a linfopoese $\mathrm{T}$; assim, podemos considerar que nosso modelo experimental é capaz de reproduzir os efeitos benéficos do TNF- $\alpha$, sobre o controle transcricional mediado pela via Notch, mesmo sem termos identificado efeitos com marcadores utilizados e no período de tempo avaliado.

Em suma, a avaliação de marcadores de superfície, expressos especificamente em células durante o comprometimento com a linhagem linfocítica $\mathrm{T}$, nos permitiu concluir que, nas condições experimentais utilizadas neste trabalho, as células-tronco hematopoéticas CD34+ de sangue de cordão umbilical foram induzidas à diferenciação em células $\mathrm{T}$ com sucesso. O processo de diferenciação das CTH ocorreu nos cocultivos com as células estromais expressando o ligante de Notch, Delta-like 1 (e na presença das citocinas IL-7 e Flt3-L), mas não quando cocultivadas com as células OP9-GFP (nosso controle).

Estes resultados validam, portanto, as condições experimentais utilizadas por nós visando a avaliação dos mecanismos de regulação transcricional, ocorrendo no início do processo de comprometimento das $\mathrm{CTH}$ com a linhagem $\mathrm{T}$ linfocítica, mediante ativação da via Notch, bem como o papel de TNF- $\alpha$ na modulação deste processo.

\subsection{Limitações da Abordagem Experimental Utilizada}

Apesar de conseguirmos inferir a dependência da via Notch para a transcrição de alguns fatores, a abordagem experimental utilizada por nós, apresenta certas limitações, algumas delas, apontadas abaixo. 
Observamos uma variação experimental considerável para todos os transcritos avaliados neste trabalho, mesmo quando submetidos a condições bastante semelhantes, ou seja, empregando células estromais em mesma linhagem e em mesma quantidade, cultivo sob as mesmas condições e mesmo período, com a mesma quantidade de $\mathrm{CTH} \mathrm{CD}_{3} 4^{+}$e com os mesmos tratamentos. Isso, de acordo com a literatura, pode ser devido a variação na densidade do ligante de Notch (Dallas et al., 2005).

Dallas e colaboradores mostraram que menores densidades de Delta-like1 induzem sinalização Notch suficiente para o aumento do número de precursores de células B, enquanto, que grandes densidades desse ligante elevam o número de células T. Além disso, a curta exposição de Notch ao ligante Delta-Like 1 mostrou-se suficiente para induzir a diferenciação de células T e para aumentar o potencial de células T de CD34+ (Lefort, 2006).

A diferença do nível de expressão dos transcritos também pode ser atribuída a diferenças de amostra para amostra das $\mathrm{CTH}$, outro motivo poderia ser que a intensa sinalização de Delta-like 1 induz a apoptose de células $\mathrm{CD}^{+} 4^{+}$e reduz a diferenciação mieloide, enquanto não afeta o desenvolvimento de células T (Delaney et al., 2005), desta forma, a apoptose celular das $\mathrm{CTH} \mathrm{CD} 34^{+}$poderia ser responsável pela variação nos níveis de expressão dos transcritos.

Em alguns experimentos deste trabalho, a variação na intensidade da sinalização de DL1 pode ter resultado da obtenção de bolsas de SCU em dias posteriores ao programado, isso porque a montagem de placas de cocultivo (plaqueamento das células estromais OP9GFP e OP9-DL1) ocorria três dias antes do inicio do processo de separação imunomagnética das células $\mathrm{CD}^{+} 4^{+}$. A falta de bolsas no dia programado e seu recebimento no dia seguinte resultavam em cocultivos com um maior número de células estromais, e consequentemente com uma maior densidade de ligante DL1. 
De acordo com Fernandez e colaboradores (2008), o tratamento de células estromais com TNF- $\alpha$ numa concentração de $10 \mathrm{ng} / \mathrm{ml}$ e por $24 \mathrm{~h}$ pode modular positivamente o nível de expressão de ligantes de Notch (em específico Jagged 2). Apesar de termos utilizado uma concentração de TNF- $\alpha 40$ vezes menor e por metade do tempo, não podemos descartar a possibilidade de que as células OP9-DL1 tenham os níveis de ligantes de Notch (ou qualquer outro fator) aumentados no período avaliado. O desenho experimental utilizado por nós não permite excluir esta possibilidade, uma vez que a inibição de síntese protéica foi feita exclusivamente nas $\mathrm{CTH}$, deixando as células OP9-DL1 livres para expressarem proteínas sintetizadas de novo, durante o período de incubação com o TNF- $\alpha$. Ainda, enquanto a modulação da expressão dos transcritos nas CTH tratadas por CHX pelo TNF- $\alpha$, na presença concomitante do inibidor da via Notch (DAPT), não possa ser atribuída à sinalização de ligantes de Notch expressos pelas células OP9-DL1, ela pode, ainda, resultar da produção aumentada de outros fatores pelas células OP9-DL1. Assim, avaliação de efeitos indiretos, mediados por proteínas sintetizadas pelas células OP9-DL1, dependeria de avaliações adicionais com o bloqueio da síntese em todas as células em cocultivo.

Apesar das dificuldades acima, conseguimos analisar nossos resultados e fazer importantes inferências sobre as vias de sinalização Notch e NF-אB durante o processo de diferenciação linfocítica $\mathrm{T}$ a partir de células-tronco hematopoéticas humanas sobre cocultura com as células OP9. Além de indicar a ação dessas vias de sinalização sobre a transcrição de diferentes fatores. 
6. CONCLUSÕES 
As principais observações obtidas por nós neste trabalho estão destacadas a seguir:

- Durante o cocultivo com células OP9-DL1, proteínas sintetizadas de novo atuam positivamente na transcrição de HEY1, principalmente através da modulação direta da sinalização da via Notch. Por outro lado, o TNF- $\alpha$ induz a síntese de proteínas com efeito positivo sobre a transcrição de HEY1, atuando independentemente da via Notch.

- Durante o cocultivo com células OP9-DL1, proteínas sintetizadas de novo atuam negativamente sobre a transcrição de HES1, por mecanismos independentes da via Notch. O TNF- $\alpha$ exerce um efeito negativo sobre a transcrição de HES1, independente da via Notch, e mediado por proteínas sintetizadas de novo.

- A transcrição de GATA3 é modulada positivamente por TNF- $\alpha$, através de mecanismos atuando tanto de forma independente, bem como diretamente sobre a via Notch, Estes mecanismos independem da síntese de novo de proteínas, as quais atuam negativamente sobre a transcrição de GATA3.

- A transcrição de HOXB4 é regulada positivamente pela ativação da via Notch, não diretamente (como alvo do complexo NICD/CSL), mas, indiretamente, provavelmente pela de-repressão de outro fator transcricional diretamente envolvido na transcrição de HOXB4. Ainda, TNF- $\alpha$ atua positivamente na transcrição.

Nossos resultados revelam que a expressão de GATA3, mediante a ativação da via Notch (por DL1), ocorre muito antes do relatado na literatura, implicando num papel precoce no controle dos eventos iniciais envolvidos no comprometimento das $\mathrm{CTH}$ em linfócitos T. Ainda, a modulação da indução transcricional de diferentes alvos de Notch (como HES1, HEY1 e GATA3) por uma concentração fisiologicamente relevante de TNF- $\alpha$ (muito inferior às usualmente utilizadas nos ensaios in vitro relatados na literatura), evidencia a importância deste fator como coadjuvante nos processos ligados à auto-renovação e ao comprometimento e à diferenciação T linfocítica. Ainda, dado que as proteínas de HES e HEY interagem com 
fatores GATA, modulando sua atividade transcricional (Fischer et al., 2007); os diferentes mecanismos de controle transcricional atuando sobre a transcrição destes fatores, atuariam de forma a orquestrar a atividade destes fatores nos diferentes processos biológicos em que atuam.

Finalmente, neste trabalho, nós estabelecemos de maneira inédita, o papel da via Notch, na regulação transcricional do fator HOXB4, estabelecendo uma ligação direta da via Notch com os processos de auto-renovação controlados por HOXB4. A identificação da relação entre estes fatores tem implicações diretas no entendimento dos mecanismos controlando a proliferação de progenitores hematopoéticos, tanto na emergência das célulastronco no embrião (a partir do endotélio hemogênico), como nos passos iniciais de colonização do timo, com a proliferação dos progenitores e seu comprometimento frente à ativação da via Notch. Finalmente, a interação entre a via Notch e o fator HOXB4, bem como do papel de TNF nesta relação, têm implicações diretas no estudo de situações como o transplante de $\mathrm{CTH}$, assim como no estudo de mecanismos alterados em situações patológicas, como as leucemias. 
7. REFERÊNCIAS BIBLIOGRÁFICAS 
Aguilera, C.; Hoya-Arias, R.; Haegeman, G.; Espinosa, L.; Bigas, A. (2004) Recruitment of I $\kappa \mathrm{B} \alpha$ to the hes 1 promoter is associated with transcriptional repression. PNAS, 101 (47), 16537-16542.

Amsen, D.; Antov, A.; Jankovic, D.; Sher, A.; Radtke, F.; Souabni, A.; Busslinger, M.; McCright, B.; Gridley, T.; Flavell, R.A. (2007) Direct regulation of Gata3 expression determines the $\mathrm{T}$ helper differentiation potential of Notch. Immunity., 27, 89-99.

Ang, H.L.; Tergaonkar, V. (2007) Notch and NFкB signaling pathways: do they collaborate in normal vertebrate brain development and function? BioEssays, 29, 1039-1047.

Artavanis-Tsakonas, S.; Rand, M.D.; Lake, R.J. (1999) Notch signaling: cell fate control and signal integration in development. Science, 284, 770-776.

Awong, G.; Herer, E.; Surth, C.D.; Dick, J.E.; La Motte-Mohs, R.N.; Züñiga-Pflücker, J.C. (2009) Characterization in vitro and engraftment potential in vivo of human progenitor T cells generated from hematopoietic stem cells. Blood, 114, 972-982.

Awong, G.; La Motte-Mohs, R.N.; Zúñiga-Pflücker, J.C. (2008). In vitro human T cell development directed by Notch-Ligand interactions. Methods Mol. Biol. 430, 135142.

Bachmann, M.; Dragoi, C.; Poleganov, M.A.; Pfeilschifter, J.; Mühl, H. (2007) Interleukin-18 directly activates T-bet expression and function via p38 mitogen-activated protein kinase and nuclear factor-KB in acute myeloid leukemia-derived predendritic KG-1 cells. Mol. Câncer Ther., 6 (2), 723-731.

Baum, C.M.; Weissman, I.L.; Tsukamoto, A.S.; Buckle, A.M.; Peault, B. (1992) Isolation of a candidate human hematopoietic stem cell population. Proc Natl acad Sci USA, 89, 2804-2808.

Beck, R.C.; Padival, M.; Yeh, d.; Ralston, J.; cooke, K.R.; Lowe, J.B. (2009) The Notch ligands Jagged2, Delta1, and Delta4 induce differentiation and expansion of functional human NK cells from $\mathrm{CD}_{3} 4^{+}$cord blood hematopoietic progenitor cells. Biol. Blood Marrow Transplant 15, 1026-1037.

Beinke, S.; Ley, S.C. (2004) Functions of NF-kappaB1 and NF-kappaB2 in immune cell biology. Biochem.J., 382, 393-409.

Bhattacharya, A.; Slatter, M.A.; Chapman, C.E.; Barge, D.; Jackson, A.; Flood, T.J.; Abinun, M.; Cant, A.J.; Gernnery, A.R. (2005) Single centre experience of umbilical cord stem cell transplantation for primary immunodeficiency. Bone Marrow Transplant., 36, 295-299. 
Bigas, A.; Robert-Moreno, A.; Espinosa, L. (2010) The Notch pathway in the developing hematopoietic system. Int. J. Dev. Biol., (54) 1175-1188.

Blank, U.; Karlsson, G.; Karlsson, S. (2008) Signaling pathways governing stem-cell fate. Blood, 111(2), 492-503.

Blom B, Spits H. (2006) Development of human lymphoid cells. Annu Rev Immunol. 24, $287-$ 320.

Bonizzi, G.; Karin, M. (2004) The two NFkB activation pathways and their role in innate and adaptive immunity. Trends Immunol., 25, 280-288.

Borggrefe, T.; Oswald, F. (2009) The Notch signaling pathway: Transcriptional regulation at Notch target genes. Cell. Mol. Life Sci., 66, 1631-1646.

Bren, G.D.; Solan, N.J.; Miyoshi, H.; Pennington, K.N.; Pobst, L.J.; Paya, C.V. (2001) Transcription of the RelB gene is regulated by NF-kappaB. Oncogene, 20, 77227733.

Buske, C.; Feuring-Buske, M.; Abramovich, C.; Spiekermann, K.; Eaves, C.J.; Coulombel, L.; Sauvageau, G.; Hogge, D.E.; Humphries, R.K. (2002) Deregulated expression of HOXB4 enhances the primitive growth activity of human hematopoietic cells. Blood, 100, $862-868$.

Chadwick, N.; Zeef, L.; Portillo, V.; Fennessy, C.; Warrander, F.; Hoyle, S.; Buckle, A.M. (2009) Identification of novel Notch target genes in T cell leukaemia. Molecular Cancer, 8: 35 .

Chadwick, N.; Nostro, M.C.; Baron, M.; Mottram, R.; Brady, G.; Buckle, A.M. (2006) Notch signaling induces apoptosis in primary human $\mathrm{CD} 34^{+}$hematopoietic progenitor cells. Stem Cells, 25, 203-210.

Challen, G.A.; Goodell, M.A. (2010) Runx 1 isoforms show differential expression patterns during hematopoietic development but have similar functional effects in adult hematopoietic stem cells. Experimental Hematology, 38, 403-416.

Chari,S.; Winandy, S. (2008) Ikaros regulates Notch target gene expression in developing thymocytes. The Journal of Immunology, 181, 6265-6274.

Chen, L.; Fischle, W.; verdin, E.; Greene, W.C. (2001) Duration of nuclear NF-KB action regulated by reversible acetylation. Science, 293, 1653-1657. 
Cheng, P.; Zlobin, A.; Volgina, V.; Gottipati, S.; Osborne, B.; Simel, E.J.; Miele, L.; Gabrilovich, D.I. (2001) Notch-1 regulates NF-kappaB activity in hemopoietic progenitor cells. J.Immunol., 167, 4458-4467.

Chiba S. (2006) Notch signaling in stem cell systems. Stem Cells, 24, 2437-2447.

Civin, C.I.; Gore, S.D. (1993) Antigenic analysis of hematopoiesis: a review. J Hematother, 2, 137-144.

Civin, C.I. (1990) Human monomyeloid cell membrane antigens. Exp. Hematol. 18, 461-467.

Cohen, Y.; Nagler, A. (2004) Umbilical cord blood transplantation - how when and for whom? Blood Rev. 18, 167-179.

Corre, S.; Galibert, M.D. (2005) Upstream stimulating factors: highly versatile stressresponsive transcription factors. Pigment Cell Res., 18 (5), 337-348.

Corredor, J.; Yan, F.; Shen, C.C.; Tong, W.; John, S.K.; Wilson, G.; Whitehead, R.; Polk, D.B. (2003) Tumor necrosis factor regulates intestinal epithelial cell migration by receptor-dependent mechanisms. Am J Physiol Cell Physiol., 284(4), C953-61.

Curry, C.L.; Reed, L.L.; Nickoloff, B.J.; Miele, L. Foreman, K.E. (2006) Notch-independent regulation of Hes-1 expresion by c-Jun N-terminal kinase signaling in human endothelial cells. Laboratory Investigation, 86, 842-852.

Dai, G.; Sakamoto, H.; Shimoda, Y.; Fujimoto, T.; Nishikawa, S.; Ogawa, M. (2006) Overexpression of c-Myb increases the frequency of hemogenic precursors in the endothelial cell population. Genes Cells, 11, 859-870.

Dallas, M.H.; Varnum-Finney, B.; Delaney, C.; Kato, K.; Bernstein, I.D. (2005) Density of the Notch ligand Delta 1 determines generation of $\mathrm{B}$ and $\mathrm{T}$ cell precursors from hematopoietic stem cells. The Journal of Experimental Medicine, 201 (9), 13611366.

de Smedt, M.; Hoebeke, I.; Plum, J. (2004) Human bone marrow CD34 ${ }^{+}$progenitor cells mature to T cells on OP9-DL1 stromal cell line without thymus microenvironment. Blood Cells Mol.Dis., 33, 227-232.

de Smedt, M.; Reynvoet, K.; Kerre, T.; Taghon, T.; Verhasselt, B.; Vandekerckhove, B.; Leclercq, G.; Plum, J. (2002) Active form of Notch imposes T cell fate in human progenitor cells. J.Immunol., 169, 3021-3029. 
de Wynter, E.A.; Buck, D.; Hart, C.; Heywood, R.; Coutinho, L.H.; Clayton, A.; Rafferty, J.A.; Burt, D.; Guenechea, G.; Bueren, J.A.; Gagen, D.; Fairbairn, L.J.; Lord, B.I.; Testa, N.G. (1998) CD $34^{+} \mathrm{AC} 133^{+}$cells isolated from cord blood are highly enriched in long-term culture-initiating cells, NOD/SCID-repopulating cells and dendritic cell progenitors. Stem Cells, 16, 387-396.

de Wynter, E.A.; Nadali, G.; Coutinho, L.H.; esta, N.G. (1996) Extensive amplification of single cells from CD34+ subpopulations in umbilical cord blood and identification of long-term culture-initiating cells present in two subsets. Stem Cell, 14(5), 566-576.

Deftos, M.L.; Bevan, M.J. (2000) Notch signaling in T cell development. Current Opinion in Immunology, 12, 166-172.

Dejardin, E. (2006) The alternative NF-kB pathway from biochemistry to biology: Pitfals and promises for future drug development. Biochemical pharmacology 72, 1161-1179.

Delaney, C.; Varnum-Finney, B.; Aoyama, K. (2005) Dose-depentent effects of the Notch ligand Delta 1 on ex vivo differentiation and in vivo marrow repopulating ability of cord blood cells. Blood, 106, 2693-2699.

Dontje, W.; Schotte, R.; Cupedo, T.; Nagasawa, M.; Scheeren, F.; Gimeno, R.; Spits, H.; Blom, B. (2006) Delta-like1-induced Notch1 signaling regulates the human plasmacytoid dendritic cell versus T-cell lineage decicion through control of GATA3 and Spi-B. Immunobiology, 107 (6), 2446-2451.

Dorsam, S.T.; Ferrell, C.M.; Dorsam, G.P.; Derynck, M.K.; Vijapurkar, U.; Khodabakhsh, D.; Pau, B.; Bernstein, H.; Haqq, C.M.; Largman, C.; Lawrence, H.J. (2004) The transcriptome of the leukemogenic homeoprotein HOXA9 in human hematopoietic cells. Blood, 103, 1676-1684.

Dudley, D.D.; Wang, H.C.; Sun, X.H. (2009) Hes1 potentiates T cell lymphomagenesis by up-regulating a subset of Notch target genes. PLOS ONE 4(8), e6678. doi: 10,1371/journal.pone.0006678.

Duncan, A.W.; Rattis, F.M.; DiMascio, L.N.; Congdon, K.L.; Pazianos, G.; Zhao, C.; Yoon, K.; Cook, J.M.; Willert, K.; Gaiano, N.; Reya, T. (2005) Integration of Notch and Wnt signaling in hematopoietic stem cell maintenance. Nature Immunology, 6(3), 314-322.

Dzierzak, E. (1999) Embryonic beginnings of definitive hematopoietic stem cells. Ann.N.Y.Acad.Sci., 872, 256-262. 
Egawa, T.; Tillman, R.E.; Naoe, Y.; Taniuchi, I.; Littman, D.R. (2007) The role of the Runx transcription factors in thymocyte differentiation and in homeostasis of naive $\mathrm{T}$ cells. J.Exp.Med., 204, 1945-1957.

Espinosa, L.; Santos, S.; Inglés-Esteve, J.; Münoz-Canoves, P.; Bigas, A. (2002). P65-NF-кB synergizes with Notch to activate transcription by triggering cytoplasmic translocation of the nuclear receptor corepressor N-Cor. Journal of Cell Science 115, 1295-1303.

Fang, T.C.; Yashiro-Ohtani, Y.; Del, B.C.; Knoblock, D.M.; Blacklow, S.C.; Pear, W.S. (2007) Notch directly regulates Gata3 expression during $\mathrm{T}$ helper 2 cell differentiation. Immunity., 27, 100-110.

Farnie, G.; Clarke, R.B. (2007) Mammary Stem Cells and Breast Cancer - role of Notch Signalling. Stem Cell Rev. 3, 169-175.

Fernandez, L.; Rodriguez, S.; Huang, H.; Chora, A.; Fernandes, J.; Mumaw, C.; Cruz, E.; Pollok, K.; Cristina, F.; Price, J.; Ferkowicz, M.J.; Scadden, D.T.; Clauss, M.; Cardoso, A.A.; Carlesso, N. (2008) Tumor necrosis factor- $\alpha$ and endothelial cells modulate Notch signaling in boné marrow microenvironment durinf inflammation. Experimental Hematology, 36, 545-558.

Ferrell, C.M.; Dorsam, S.T.; Ohta, H.; Humphries, R.K.; Derynck, M.K.; Haqq, C.; Largman, C.; Lawrence,H.J. (2005) Activation of stem-cell specific genes by HOXA9 and HOXA10 homeodomain proteins in CD $34^{+}$human cord blood cells. Stem Cells, 23, 644-655.

Fischer, A.; Gessler, M. (2007) Delta-Notch-and then? Protein interactions and propsed modes of repression by Hes and Hey bHLH factors. Nucleic Acids Research, 35 (14), 4583-4596.

Frassoni, F.; Podesta, M.; Maccario, R.; Giorgiani, G.; Rossi, G.; Zecca, M.; Bacigalupo, A.; Piaggio, G.; Locatelli, F. (2003) Cord blood transplantation provides better reconstitution of hematopoietic reservoir compared with bone marrow transplantation. Blood, 102, 1138-1141.

Frey, M.A.; Guess, C.; Allison, J.; Kurtzberg (2009) Umbilical cord stem cell transplantation. Seminars in Oncology Nursing, 15 (2), 115-119.

Friedman, A.D. (2009) Cell cycle and developmental control of hemtopoiesis by Runx1. Journal of Cellular Physiology, 219, 520-524. 
Gao, J.; Yan, X.L.; Li, R.; Liu, Y.; He, W.; Sun, S.; Zhang, Y.; Liu, B.; Xiong, J.; Mao, N. (2010) Characterization of OP9 as authentic mesenchymal stem cell line. J. Genet. Genomics, 37, 475-482.

Ghosh, S.; May, M.J.; Kopp, E.B. (1998) NFkB and Rel proteins: evoluntionary conserved mediators of immune responses. Annu. Rev. Immunol., 16, 225-260.

Giampaolo, A., Sterpetti, P.; Bulgarini, D.; Samoggia, P.; Pelosi, E.; Valtieri, M.; Peschle, C. (1994) Key functional role and lineage-specific expression of selected HoxB genes in purified hematopoietic progenitor differentiation. Blood. 84,3637-3647.

Giannola, D.M.; Shlomchik, W.D.; Jegathesan, M.; Liebowitz, D.; Abrams, C.S.; Kadesch, T.; Dancis, A.; Emerson, S.G. (2000) Hematopoietic expression of HOXB4 is regulated in normal and leukemic stem cells through transcriptional activation of the HOXB4 promoter by upstream stimulating factor (USF)-1 and USF-2. J.Exp.Med., 192, 1479-1490.

Giraldo, E.; Martin-Cordero, L.;Hinchado, M.D.; Garcia, J.J.; Ortega, E. (2009) Role of phosphatidylinositol-3-kinase (PI3K), extracellular signal-regulated kinase (ERK) and nuclear transcription factor kappa $\mathrm{b}(\mathrm{NF}-\mathrm{kb})$ on neutrophil phagocytic process of Candida albicans. Mol Cell Biochem, 333 (1-2), 115-120.

Gluckman, E.; Rocha, V.; Boyer-Chammard, A.; Locatelli, F.; Arcesse, W.; Pasquini, R.; Ortega, J.; Souillet, G.; Ferreira, E.; Laporte, J.P.; Fernandez, M.; Chastang, C. (1997) Outcome of cord-blood transplantation from related and unrelated donors. Eurocord transplantat group and the European blood and marrow transplantation group. N. Engl. J. Med. 337, 373-381.

Gluckman, E.; Broxmeyer, H.E.; Auerbach, A.D.; Friedman, H.S.; Douglas, G.W.; Devergie, A. Esperou, H.; Thierry, D.; Socie, G.; Lehn, P.; Cooper, S.; English, D.; Kurtzberg, J.; Bard, J.; Boyse, E.A. (1989) Hematopoietic Reconstitution in a Patient with Fanconis Anemia by Means of Umbilical-Cord Blood from An Hla-Identical Sibling. New England Journal of Medicine, 321 (17), 1174-1178.

Gomes, T.; Pranke, P. (2008) Comparação Comparison between preterm and full-term newborn umbilical cord blood stem cells: a review. RBAC, $\mathbf{4 0}$ (1), 25-30.

Gravano, D.M.; Manilay, J.O. (2010) Inhibition of proteolysis of Delta-like-1 does not promote or reduce T-cell development potential. Immunology and Cell Biology, $\mathbf{8 8}$ (7), 1-8.

Guan, E.; Wang, J.; Laborda, J.; Norcross, M.; Baeuerle, P.A.; Hoffman, T. (1996) T cell leukemia-associated human Notch/translocation-associated Notch homologue has I 
kappa B-like activity and physically interacts with nuclear factor-kappa B proteins in T cells. J. Exp. Med., 183 (5): 2025-32.

Gunsilius, E.; Gastl, G.; Petzer, A.L. (2001) Hematopoietic stem cells. Biomed Pharmacother 55, 186-194.

Haddad, R.; Pflumio, F.; Vigon, I.; Visentin, G.; Auvray, C.; Fichelson, S.; Amsellem, S. (2008) The HOXB4 Homeoprotein Differentially Promotes ex vivo Expansion of Early Human Lymphoid Progenitors. Stem Cells. 26(2), 312-322.

Hare, K.J.; Jenkinson, E.J.; Anderson, G. (1999) In vitro models of T cell development. Seminars in Immunology 11, 3-12

Haspel, R.L.; Miller, K.B. (2008) Hematopoietic stem cells: source matters. Curr Stem Cell Res Ther, 3, 229-236.

Healy, L.; May, G.; Gale, K.; Grosveld, F.; Enver, T. (1995) The stem cell antigen CD34 functions as a regulator of hemopoietic cell adhesion. Proc Natl Acad Sci USA 92, 12240-12244.

Hirai, H.; Samokhvalov, I.M.; Fujimoto, T.; Nishikawa, S.; Imanishi, J.; Nishikawa, S. (2005) Involvement of Runx 1 in the down-regulation of fetal liver kinase-1 expression during transition of endothelial cells to hematopoietic cells. Blood, 106, 1948-1955.

Hirata, H.; Yoshiura, S.; Ohtsuka, T.; Bessho, Y.; Harada, T.; Yoshikawa, K.; Kageyama, R. (2002) Oscillatory Expression of the bHLH Factor Hes1 Regulated by a Negative Feedback Loop. Science, 298, 840-842.

Ho, I.; Tai, T.; Pai, S. (2009). Gata3 and the T-cell linage: essential functions before and after t-helper-2-cell differentiation. Nature Reviews Immunol. 9, 125-135.

Ho, I.C.; Pai, S.Y. (2007) GATA-3 - not just for Th2 cells anymore. Cell Mol.Immunol., 4, 15-29.

Hoebeke, I.; de Smedt, M.; van de Walle, I.; Reynvoet, K.; de Smet, G.; Plum, J.; Lectercq (2006) Overexpression of HES-1 is not sufficient to impose T-cell differentiation on human hematopoietic stem cells. Immunobiology, 107 (7), 2879-2881.

Hoffmann, A.; Natoli, G.; Ghosh, G. (2006) Transcriptional regulation via the NFkB signaling module. Oncogene, 25, 6706-6716. 
Hosoya, T.; Kuroha, T.; Mariguchi, T.; Cummings, D.; Maillard, I.; Lim, K.C.; Engel, J.D. (2009) GATA-3 is requerid for early T lineage progenitor development. JEM, 206 (13), 2987-3000.

Hozumi, K.; Negishi, N.; Suzuki, D.; Abe, N.; Sotomaru, Y.; Tamaoki, N.; Mailhos, C.; IshHorowicz, D.; habu, S.; Owen, M. (2004) Delta-like 1 is necessary for the generation of marginal zone B cells but not $\mathrm{T}$ cells in vivo. Nat. immunol., 5, 638-644.

Hu, H.; Djuretic, I.; Sundrud, M.S.; Rao, A. (2007) Transcriptional partners in regulatory T cells: Foxp3, Runx and NFAT. Trends Immunol., 28, 329-332.

Iso, T.; Kedes, L.; Hamamori, Y. (2003) Hes and Herp families: Multiple effectores of the Notch signaling pathway. Journal of cellular physiology, 194, 237-255.

Iso, T.; Sartorelli, V.; Poizat, C.; Iezzi, S.; Wu, H.Y.; Chung, G.; Kedes, L.; Hamamori, Y. (2001) Herp, a novel heterodimer partner of hes/e(spl) in notch signaling. Mol Cell Biol., 21, 6080-6089.

Jaffredo, T.; Bollerot, K.; Sugiyama, D.; Gautier, R.; Drevon, C. (2005) Tracing the hemangioblast during embryogenesis: developmental relationships between endothelial and hematopoietic cells. Int.J.Dev.Biol., 49, 269-277.

Jaleco, A.C.; Neves, H.; Hooijberg, E.; Gameiro, P.; Clode, N.; Haury, M.; Henrique, D.; Parreira, L. (2001) Differential effects of Notch ligands Delta-1 and Jagged-1 in human lymphoid differentiation. J Exp Med., 194 (7), 991-1002.

Johnston, D.A.; Dong, B.; Hughes, C.C.W. (2009). TNF induction of jagged-1 in endothelial cells in NF-кB-dependent. Gene, 435, 36-44.

Kageyama, R.; Ohtsuka, T.; Tomita, K. (2000) The bHLH gene Hes1 regulates differentiation of multiple cell types. Mol Cells., 29(1),1-7.

Katoh, M.; Katoh, M. (2007) WNT signaling pathway and stem cell signaling network. Clin. Cancer Res. 13, 4042-4045.

Kekarainen, T.; Mannelin, S.; Laine, J.; Jaatinen, T. (2006) Optimization of immunomagnetic separation for cord blood-derived hematopoietic stem cell. BCM Cell Biology.7:30

Kutlesa, S.; Zayas, J.; Valle, A.; Levy, R.B.; Jurecic, R. (2009) T-cell differentiantion of multipotent hematopoietic cell line EML in the OP9-DL1 coculture system. Experimental Hematology 37, 909-923. 
Kobayashi, T.; Kageyama, R. (2010) Hes1 regulates embryonic stem cell differentiation by suppressing Notch signaling. Genes to Cells, 15 (7), 689-698.

Kubo, M. (2007) Notch: filling a hole in T helper 2 cell differentiation. Immunity., 27, 3-5.

Kumano, K.S.; Chiba, A.; Kunisato, M.S.; Saito, T.; Nakagami-Yamaguchi, E.; Yamaguchi, T.; Masuda, S.; Shimizu, K.; Takahashi, T.; Ogawa, Y.; Hamada, H.; Hirai. (2003) Notch1 but not Notch2 is essential for generating hematopoietic stem cells from endothelial cells. Immunity, 18, 699-711.

Kurita, R.; Sasaki, E.; Yokoo, T.; Hiroyama, T.; Takasugi, K.; Imoto, H.; Izawa, K.; Dong, Y.; Hashiguchi, T.; Soda, Y.; Maeda, T.; Suehiro, Y.; Tanioka, Y.; Nakazaki, Y.; Tani, K. (2006) Tall/Scl gene transduction using a lentiviral vector stimulates highly efficient hematopoietic cell differentiation from common marmoset (Callithrix jacchus) embryonic stem cells. Stem Cells, 24, 2014-2022.

Kuroda, K.; Tani, S.; Tamura, K.; Minoguchi, S.; Kurooka, H.; Honjo, T. (1999) Deltainduced Notch signaling mediated by RBP-J inhibits MyoD expression and myogenesis. The journal of biological chemistry, 274 (11), 7238-7244.

Kyba, M.; Perlingeiro, R.C.; Daley, G.Q. (2002) HoxB4 confers definitive lymphoid-myeloid engraftment potential on embryonic stem cell and yolk sac hematopoietic progenitors. Cell, 109, 29-37.

La Motte-Mohs, R.N.; Herer, E.; Zuniga-Pflucker, J.C. (2005) Induction of T-cell development from human cord blood hematopoietic stem cells by Delta-like 1 in vitro. Blood, 105, 1431-1439.

Lahmar, M.; Catelain, C.; Poirault, S.; Dorsch, M.; Villeval, J.L.; Vainchenker, W.; Albagli, O.; Lauret, E. (2008) Distinct effects of the soluble versus membrane-bound forms of the Notch ligand delta-4 on human $\mathrm{CD} 34^{+} \mathrm{CD} 38^{\text {low }}$ cell expansion and differentiation. Stem cells 26, 621-629.

Laughlin, M.J.; Barker, J.; Bambach, B.; Koc, O.N.; Rizzieri, D.A.; Wagner, J.E.; Gerson, S.L.; Lazarus, H.M.; Cairo, M.; Stevens, C.E.; Rubinsteins, P.; Kurtzberg, J. (2001) Hematopoietic engraftment and survival in adult recipients of umbilical cord blood from unrelated donor. $N$ Engl J Med., 344, 1815-1822.

Lawrence, H.J.; Sauvageau, G.; Humphries, R.K.; Largman, C. (1996) The role of HOX homeobox genes in normal and leukemic hematopoiesis. Stem Cells, 14, 281-291.

Lee, J.H.; Suk, J.; Park, J.; Kim, S.B.; Kwak, S.S.; Kim, J.W.; Lee, C.H.; Byun, B.; Ahn, J.K.; Joe, C.O. (2009) Notch signal activates hypoxia pathway through hes1-dependent 
src/signal transducers and activators of transcription 3 pathway. Mol. Cancer res. 7(10), 1663-1671.

Lefort, N.; Benne, C.; Lelière, J.D.; dorival, c.; Balbo, M.; Sakano, S.; Coulombel, L.; Lévy, Y. (2006) short exposure to Notch ligand Delta-4 is sufficient to induce T-cell differentiation program and to increase the $\mathrm{T}$ cell potential of pimary human CD34 cells. Experimental Hematology, 34, 1720-1729.

Lehar, S.M.; Bevan, M.J. (2002) T cell development in culture. Immunity, 17, 689-692.

Li, X.; Stark, G.R. (2002) NF-KB-dependet signaling pathways. Experiemntal Hematology, 30 (2), 285-296

Liptay,S.; Schmid,R.M.; Nabel,E.G.; Nabel,G.J. (1994) Transcriptional regulation of NFkappa B2: evidence for kappa B-mediated positive and negative autoregulation. Mol.Cell Biol., 14, 7695-7703.

Lombardi,L.; Ciana,P.; Cappellini,C.; Trecca,D.; Guerrini,L.; Migliazza,A.; Maiolo,A.T.; Neri,A. (1995) Structural and functional characterization of the promoter regions of the NFKB2 gene. Nucleic Acids Res., 23, 2328-2336.

Magri, M.; Yatim, A.; Benne, C.; Balbo, M.; Henry, A.; Serraf, A.; Sakano, S.; Gazzolo, L.; Lévy, Y.; Lelièvre, J.D. (2009) Notch ligands potentiate IL-7-driven proliferation and survival of human thymocyte precursors. European Journal of Immunology, 39, 1231-1240.

Maier, M.M.; Gessler, M. (2000) Comparative analysis of the Human and Mouse Hey1 promoter: Hey genes are new Notch target genes. Biochemical and Biophysical Research Communications, 275, 652-660.

Martin, C.H.; Woll, P.S.; Ni, Z.; Zúñiga-Pflücker, J.C.; Kaufman, D.S. (2008) Differences in lymphocyte developmental potential between human embryonic stem cell and umbilical cord blood-derived hematopoietic progenitor cells. Hematopoiesis and Stem Cells, 112 (7), 2730-3029.

Mikels, A.J.; Nusse, R. (2006) Wnts as ligands: processing, secretion and reception. Oncogene, 25, 7461-7468.

Milson, M.D.; Schiedlmeier, B.; Bailey, J.; Kim, M.O.; Li, D.; Jansen, M.; Ali, A.M.; Kirby, M.; Baum, C.; Fairbairn, L.J.; Williams, D.A. (2009) Ectopic HOXB4 overcomes the inhibitory effect of tumor necrosis factor- $\alpha$ on Fanconi anemia hematopoietic stem and progenitor cells. Hematopoiesisi and Stem Cells, 21, 5111-5120. 
Mitsiadis, T.A.; Barrandon, O.; Rochat, A.; Barrandon, Y.; de Bari, C. (2007) Stem cell niches in mammals. Exp. Cell Research 313, 3377-3385.

Moretti, P.; Simmons, P.; Thomas, P. (1994) Identification of homeobox genes expressed in human haemopoietic progenitor cells. Gene. 144, 213-219.

Moynagh, P.N. (2005) The NFkB pathway. J Cell Sci., 118, 4389-4392.

Nakata, S.; Matsumura, I.; Tanaka, H.; Ezoe, S.; Satoh, Y.; Ishikawa, J.; Era, T.; Kanakura, Y. (2004) NF-kappaB family proteins participate in multiple steps of hematopoiesis through elimination of reactive oxygen species. J.Biol.Chem., 279, 55578-55586.

Nakazawa, M.; Ishii, H.; Nakamura, H.; Yoshino, S.I.; Fukamizu, A.; Nishioka, K.; Nakajima, T. (2001) NFkappaB2 (p52) promoter activation via Notch signaling pathway in rheumatoid synoviocytes. Int.J.Mol.Med., 7, 31-35.

O’Neil, J.; Grim, J.; strack, P.; Rao, S.; Tibbitts, D.; Winter, C.; Hardwick, J.; Welcker, M.; Meijerink, J.P.; Pieters, R.; Draetta, G.; Sears, R.; Clurman, B.E.; Look, A.T. (2007) FBW7 mutations in leukemic cells mediate $\mathrm{NOTCH}$ pathway activation and resistance to $\gamma$-secretase inhibitors. JEM, 204 (8), 1813-1824.

Ohkita, M.; Takaoka, m.; Shiota, Y.; Nojiri, R.; Sugii, M.; Matsumira, Y. (2002) A nuclear factos- $\kappa \mathrm{B}$ inhibitor BAY 11-7082 suppresses endothelin-1 production in cultured vascular endothelial cells. Jpn. J. Pharmacol., 89, 81-84.

Ono, M.; Yaguchi, H.; Ohkura, N.; Kitabayashi, I.; Nagamura, Y.; Nomura, T.; Miyachi, Y.; Tsukada, T.; Sakaguchi, S. (2007) Foxp3 controls regulatory T-cell function by interacting with AML1/Runx1. Nature, 446, 685-689.

Oswald, F.; Liptay, S.; Adler, G.; Schmid, R.M. (1998) NF-kappaB2 is a putative target gene of activated Notch-1 via RBP-Jkappa. Mol.Cell Biol., 18, 2077-2088.

Pai, S.Y.; Truitt, M.L.; Ting, C.N.; Leiden, J.M.; Glimcher, L.H.; Ho, I.C. (2003) Critical roles for transcription factor GATA-3 in thymocyte development. Immunity., 19, 863-875.

Panepucci, R.A.; Oliveira, L.H.B.; Zanette, D.L.; Carrara, R.C.V.; araujo, A.G.; Orellana, M.D.; de Palma, P.V.B.; Menezes, C.C.B.O.; Covas, D.T.; Zago, M.A. (2010) Increased Levels of NOTCH1, NF-kB, and other interconnected transcription factors characterize primitive sets of hematopoietic stem cells. Stem cells and Development, 19 (3), 321-332. 
Panepucci, R.A.; Calado, R.T.; Rocha, V.; Proto-Siqueira, R.; Silva, W.A.Jr.; Zago, M.A. (2007) Higher expression of transcription targets and components of the nuclear factor-kappaB pathway is a distinctive feature of umbilical cord blood CD34 precursors. Stem Cells, 25, 189-196.

Patterson, L.J.; Gering, M.; Eckfeldt, C.E.; Green, A.R.; Verfaillie, C.M.; Ekker, S.C.; Patient, R. (2007) The transcription factors Scl and Lmo2 act together during development of the hemangioblast in zebrafish. Blood, 109, 2389-2398.

Petters, C.; Steward, C.G (2003) Hematopoietic cell transplantation for inherited metabolic diseases: a overeview of outcomes and practice guidelines. Bone marrow Transplant, 31, 229-239.

Pfaffl, M.W. (2001) A new mathematical model for relative quantification in real-time RTPCR. Nucleic Acids Res., 29, e45.

Pineault, N.; Helgason, C.D.; Lawrence, H.J.; Humphries, R.K. (2002) Differential expression of Hox, Meis1, and Pbx1 genes in primitive cells throughout murine hematopoietic ontogeny. Exp. Hematol 30(1), 49-57.

Ploemacher, R.E. (1997) Stem cells: characterization and measurement. Baillière's Clinical Haematology 10, 429-444.

Plum, J.; De Smedt, M.; Leclercq, G.; Taghon, T.; Kerre, T.; Vandekerckhove, B. (2008) Human intrathymic development: a selective approach. Semin Immunopathol 30, 411-423.

Pooter, R.; Zúñiga-Pflücker, J.C. (2007) T-cell potential and development in vitro: the OP9DL1 approach. Current Opinion in Immunology, 19, 163-168.

Pyatt, D.W.; Stillman, W.S.; Yang, Y.; Gross, S.; Zheng, J.H.; Irons, R.D. (1999) An essential role for NF-kappaB in human $\mathrm{CD}_{4}\left(^{+}\right)$bone marrow cell survival. Blood, 93, 33023308 .

Radtke, F.; Wilson, A.; Mancini, S.J.; MacDonald, H.R. (2004) Notch regulation of lymphocyte development and function. Nat Immunol., 5, 247-253.

Radtke, F.; Wilson, A.; Stark, g.; Bauer, M.; van Meerwijk, J.; MacDonald, H.R.; Aguet, M. (1999) Deficient $\mathrm{T}$ cell fate specification in mice with an induced inactivation on Notch1. Immunity, 10, 547-558. 
Ramdass, B.; Maliekal, T.T.; Lakshmi, S.; Rehman, M.; Rema, P.; Nair, P.; Mukherjee, G.; Reddy, B.K.; Krishna, S.; Radhakrishna, P.M. (2007) Coexpression of Notch1 and NF-kappaB signaling pathway components in human cervical cancer progression. Gynecol.Oncol., 104, 352-361.

Rao, S.S.; O’Neil, J.; Liberator, C.D.; Hardwick, J.S.; Dai, X.; Zhang, T.; tyminski, E.; Yuan, J.; Kohl, N.E.; Richon, V.M.; Van der Ploeg, L.H.T.; Carroll, P.M.; Draetta, G.F.; Look, A.T.; Strack, P.R.; Winter, C.G. (2009) Inhibition of NOTCH signaling by gamma secretase inhibitor engages the RB pathway and elicits cell cycle exit in $\mathrm{T}$ cell acute lymphoblastic leukemia cells. Cancer Res. 69 (7), 3060-3068.

Reya, T.; Clevers, H. (2005) Wnt signalling in stem cells and cancer. Nature, 434, 843-850.

Reya, T.; Duncan, A.W.; Ailles, L.; Domen, J.; Scherer, D.C.; Willert, K.; Hintz, L.; Nusse, R.; Weissman, I.L. (2003) A role for Wnt signalling in self-renewal of haematopoietic stem cells. Nature, 423, 409-414.

Reynaud, D.; Ravet, E.; Titeux, M.; Mazurier, F.; Renia, L.; Dubart-Kupperschmitt, A.; Romeo, P.H.; Pflumio, F. (2005) SCL/TAL1 expression level regulates human hematopoietic stem cell self-renewal and engraftment. Blood, 106, 2318-2328.

Riddell, S.R.; Applebeum, F.R. (2007) Graft-versus-host disease: a surge of developments. Plos Méd., 4 (7), 1174-1177.

Ring, W.L.; Riddick, C.A.; Baker, J.R.; Glass, C.K.; Bigby, T.D. (1997) Activated lymphocytes increase expression of 5-lipoxygenase and its activating protein in THP-1 cells. American Journal Physiology Cell Physiology, 273, 2057-2064.

Rocha, V.; Wagner, J.E.; Sobocinski, K.A.; Klein, J.P.; Zhang, M.J.; Horowitz, M.M.; Gluckman, E. (2000) Graft-versus-host disease in children who have received a cordblood or bone marrow transplant from a HLA-identical sibling. Eurocord and International Bone Marrow Transplant Registry Working Committee on alternative Donor and Stem Cell Sources. N Engl J Med., 342 (25): 1846-1854.

Rothenberg, E.V.; Taghon, T. (2005) Molecular Genetics of T Cell Development. Annu. Rev. Immunol. 23, 601-649.

Sakata, D.; Taniguchi, H.; Yasuda, S.; Adachi-Morishima, A.; Hamazaki, Y.; Nakayama, R.; Miki, T.; Minato, N.; Narumiya, S. (2007) Impaired T lymphocyte trafficking in mice deficient in an actin-nucleating protein, mDia. JEM, 204 (9), 2031-2138.

Satterthwaite, A.B.; Borson, R.; Tenen, D.G. (1990) Regulation of the gene for CD34, a human hematopoietic stem cell antigen, in KG-1 cells. Blood, 75, 2299-2304. 
Sauvageau, G.; Lansdorp, P.M.; Eaves, C.E.; Hogge, D.E.; Dragowska, W.H.; Reid, D.S.; Largman, C.; Lawrence, H.J.; Humphries, R.K. (1994) Differential expression of homeobox genes in functionally distinct $\mathrm{CD} 34^{+}$subpopulations of human bone marrow cells. Proc. Natl. Acad. Sci. USA. 91:12223-12227.

Schmitt, T.M.; Zúñiga-Pflücker, J.C. (2006) T-cell development, doing it in dish. Immunological Reviews, 209, 95-102.

Schmitt, T.M.; de Pooter, R.F.; Gronski, M.A.; Cho, S.K.; Ohashi, P.S.; Zuniga-Pflucker, J.C. (2004) Induction of T cell development and establishment of T cell competence from embryonic stem cells differentiated in vitro. Nat Immunol., 5, 410-417.

Schmitt, T.M.; Zuniga-Pflucker, J.C. (2002) Induction of $\mathrm{T}$ cell development from hematopoietic progenitor cells by delta-like-1 in vitro. Immunity., 17, 749-756.

Schawanbeck, R.; Schroeder, T.; Henning, K.; Kohlhof, H.; Rieber, N.; Erfurth, M.L.; just, U. (2008) Notch signaling in embryonic and adult myelopoiesis. Cells Tissues Organs, 188, 91-102.

Shin, H.M.; Minter, L.M.; Cho, O.H.; Gottipati, S.; Fauq, A.H.; Golde, T.E.; Sonenshein, G.E.; Osborne, B.A. (2006) Notch1 augments NF-kappaB activity by facilitating its nuclear retention. EMBO J., 25, 129-138.

Singer, A.; Adoro, S.; Park, J.H. (2008) Lineage fate and intensive debate: myths, models and mechanisms of CD4- versus CD8- lineage choice. Nature, 8, 788-801.

Singh, N.; Phillips, R.A.; Iscove, N.N.; Egan, S.E. (2000) Expression of notch receptors, notch ligands, and fringe genes in hematopoiesis. Exp Hematol. 28: 527-534.

Smits, K.; De, S.M.; Naessens, E.; De, S.G.; Stove, V.; Taghon, T.; Plum, J.; Verhasselt, B. (2007) Tumor necrosis factor promotes T-cell at the expense of B-cell lymphoid development from cultured human $\mathrm{CD} 34^{+}$cord blood cells. Exp.Hematol., 35, 12721278.

Song, L.L.; Peng, Y.; Yun, J.; Rizzo, P.; Chaturvedi, V.; weijzen, S.; Kast, W.M.; Stone, P.J.B.; Santos, L.; Loredo, A.; Lendahl, U.; Sonenshein, G.; Osborne, B.; Quin, J.Z.; Pannuti, A.; Nickoloft, B.J.; Miele, L. (2008) Notch-1 associates with IKK $\alpha$ and regulates IKK activity in cervical cancer cells. Oncogene, 27, 5833-5844.

Spits, H. (2002) Development of alphabeta T cells in the human thymus. Nat.Rev.Immunol., 2, $760-772$. 
Staal, F.J.T.; Luis, T.C. (2010) Wnt signaling in hematopoiesis: Crucial factors for selfrenewal, proliferation, and cell fate decisions. Journal of Cellular Biochemistry, 109, 844-849.

Stier, S.; Cheng, T.; dombkowski, D.; Carlesso, N.; Scadden, D.T. (2002) Notch 1 activation increases hematopoietic stem cell self-renewal in vivo and favors lymphoid over myeloid linage outcome. Hematopoiesis, 99 (7), 2369-2378.

Suh, J.; Rabson, A.B. (2004) NF-KB activation in human prostate cancer: important mediador or epiphenomenon? J Cell Biochem, 91 (1), 100-117.

Sutherland, D.R.; Keating, A. (1992) The CD34 antigen: structure, biology and potential clinical applications. J Hematother, 1, 115-129

Talvensaari, K.; Clave, E.; Douay, C.; Rabian, C.; Garderet, L.; Busson, M.; Garnier, F.; Douek, D.; Gluckman, E.; Charron, D.; Toubert, A. (2002) A broad T-cell repertoire diversity and an efficient thymic function indicate a favorable long-term immune reconstitution after cord blood stem cell transplantation. Blood, 99, 1458-1464.

Tartaglia, L.A.; Pennica, D.; Goeddel, D.V. (1993) Ligand passing: the 75-kDa tumor necrosis factor (TNF) receptor recruits TNF for signaling by the 55-kDa TNF receptor. J Biol Chem., 268(25), 18542-18548.

Ting, C.N.; Olson, M.C.; Barton, K.P.; Leiden, J. M. (1996) Transcription factor Gata-3 is required for development of the T-cell lineage. Nature, 384, 474-478.

Tomita, K.; Hattori, M.; Nakamura, E.; Nakanishi, S.; Minato, N.; Kageyama, R. (1999) The bHLH gene HES1 is essential for expansion of early T cell precursors. Gene Dev, 13, 1203-1210.

Tsiftsoglou, A.; Bonovolias, I.D.; Tsiftsoglou, S.A. (2009) Multilevel targeting of hematopoietic stem cell self-renewal, differentiation and apoptosis for leukemia therapy. Pharmacology Therapeutics, 122, 264-280.

Tsuzuki, S.; Hong, D.; Gupta, R.; Matsuo, K.; Seto, M.; Enver, T. (2007) Isoform-specific potentiation of stem and progenitor cell engraftment by AML1/RUNX1. PLoS.Med., 4, e172.

van de Walle, I.; Smet, G.D.; Smedt, M.D.; Vandekerckhove, B.; Leclercq, G.; Plum, J.; Taghon, T. (2009) An early decrease in Notch activation is required for human TCR$\alpha \beta$ linage differentiation at the expense of TCR- $\gamma \delta$ T cells. Immunology, 26 (113), 2988-2998. 
Vilimas, T.; Mascarenhas, J.; Palomero, T.; Mandal, M.; Buonamici, S.; Meng, F.; Thompson, B.; Spauling, C.; Macaroum, S.; Alegre, M.L.; Kee, B.L.; Ferrando, A.; Miele, L.; Aifantis, I. (2007) Targeting the NF-kB signaling pathway in Notch1induced T-cell leukemia. Nature Medicine, 13 (1), 70-77.

Wagner, J.E.; Rosenthal, J.; Sweetman, R.; Shu, X.O.; Davies, S.M.; Ramsay, N.K.; McGlave, P.B.; Sneder, L.; Cairo, M.S. (1996) Sucessful transplantation of HLAmatched and HLA-mismatched umbilical cord blood from unrelated donors: analysis of engrafment and acute graft-versus-host disease. Blood 88, 795-802.

Wagner, W.; Ansorge, A.; Wirkner, U.; Eckstein, V.; Schwager, C.; Blake, J.; Miesala, K.; Selig, J.; Saffrich, R.; Ansorge, W.; Ho, A.D. (2004) Molecular evidence for stem cell function of the slow-dividing fraction among human hematopoietic progenitor cells by genome-wide analysis. Blood, 104, 675-686.

Walker, L.; Carlson, A.; Tan-Pertel, H.T.; Weinmaster, G.; Gasson, J. (2001) The Notch receptor and its ligands are selectively expressed during hematopoietic development in the mouse. Stem cells. 19, 543-552.

Wang, H.; Pierce, J.; Spangrude, G. (2006c) Distinct roles of IL-7 and stem cell factos in the OP9-DL1 T cell differentiation culture system. Exp. Hematol. 34 (12), 1730-1740.

Wang, Z.; Zhang, Y.; Banerjee, S.; Li, Y.; Sarkar, F.H. (2006b) Inhibition of nuclear factor kappab activity by genistein is mediated via Notch-1 signaling pathway in pancreatic cancer cells. Int.J.Cancer, 118, 1930-1936.

Wang, Z.; Banerjee, S.; Li, Y.; Rahman, K.M.; Zhang, Y.; Sarkar, F.H. (2006a) Downregulation of notch-1 inhibits invasion by inactivation of nuclear factor-kappaB, vascular endothelial growth factor, and matrix metalloproteinase-9 in pancreatic cancer cells. Cancer Res., 66, 2778-2784.

Weerkamp, F.; van Dongen, J.J.M.; Staal, F.J.T. (2006) Notch and Wnt signaling in Tlymphocyte development and acute lymphoblastic leukemia. Leukemia, 20, 11971205.

Werner, S.L.; Kearns, J.D.; Zadorozhnaya, V.; Lynch, C.; O'Dea, E.; Boldin, M.P.; Ma, A.; Baltimore, D.; Hoffmann, A. (2008) Encoding NF-kappaB temporal control in response to TNF: distinct roles for the negative regulators IkappaBalpha and A20. Genes Dev., 22, 2093-2101.

Wilson, A.; Radtke, F. (2006) Multiple functions of Notch signaling in self-renewing organs and cancer. FEBS Lett 580, 2860-2868. 
Wognum, A.W.; Eaves, A.C.; Thomas, T.E. (2003) Identification and isolation of hematopoietic stem cells. Medical Research 34, 461-475.

Yamamoto, Y.; Gaynor, B.B. (2001) Therapeutic potential if inhibition of the NF-KB pathway in the treatment of inflammation and cancer. J Clin Invest., 107 (2), 135142.

Zago, M.A.; Covas, D.T. (2006). Células-Tronco: A nova fronteira da medicina. Atheneu SP.

Zhu, J.; Giannola, D.M.; Zhang, Y.; Rivera, A.J.; Emerson, S.G. (2003) NF-Y cooperates with USF1/2 to induce the hematopoietic expression of HOXB4. Blood, 102, 24202427.

Zúñiga-Pflücker, J.C. (2004) T-cell development made simple. Nature reviews, 4, 67-72. 
8. ANEXOS 
Anexo 1

\section{APROVAÇÃO DO COMITE DE ÉTICA}

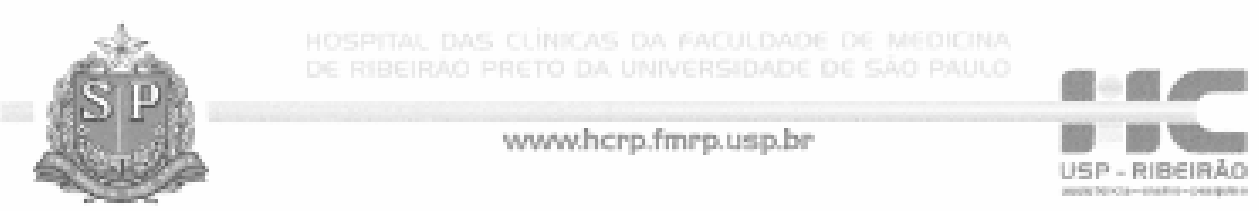

Ribeirāo Preto, 17 de abril de 2009

Oficio $\mathrm{n}^{\circ} 1222 / 2009$

$\mathrm{CEP} / \mathrm{MGV}$

Prezados Senhores,

O trabalho intitulado "PAPEL DE NF-KB E NOTCH NA REGULAÇĀO DE FATORES DE TRANSCRIÇĀO DURANTE A DIFERENCIAÇÃo IN VITRO DE CÉLULAS T A PARTIR DE CÉlULAS PROGENITORAS HEMTOPOÊTICAS CD34+" foi analisado pelo Comitê de Ética em Pesquisa, em sua $284^{n}$ Reuniāo Ordinảia realizada em 13/04/2009 e enquadrado na categoria: APROVADO, bem como o Termo de Consentimento Livre e Esclarecido, de acordo com o Processo HCRP $\mathrm{n}^{\circ} 1405 / 2009$.

Este Comite segue integralmente a Conferéncia Internacional de Harmonizaçao de Boas Práticas Clinicas (IGH-GCP), bem como a Resoluçāo no 196/ 96 CNS/MS.

Lembramos que devem ser apresentados a este CEP, O Relatório Parcial e o Relatório Final da pesquisa.

Atenciosamente.

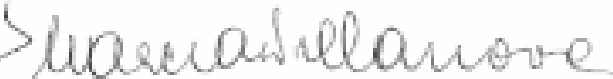

DR MARCIA GUTMARAES VILLANOVA

Vice-Coordenadora do Comitê de Ética em

Pesquisa do HCRP e da FMRP-USP

Ilustrissimos Senhores

JOSIANE LILIAN DOS SANTOS SCHIAVINATO

DR. RODRIGO ALEXANDRE PANEPUCCI (Orientador)

Fundaçâo Hemocentro de Ribeirão Preto

Comitte de Ética em Pesquisa HCRP \& FMRP-USP - Camous Univergitéric

FW/A - 0000 2733; IFB - 00002188 e Registro SISNEEICONEP $\pi^{*} 4$

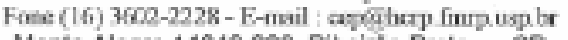

Morte Alegre 14040-600 Ribeirdo Preto SP 


\section{Anexo 2}

\section{TERMO DE CONSENTIMENTO LIVRE E ESCLARECIDO}

$\mathrm{Eu}$, abaixo assinado, tendo sido devidamente esclarecido sobre todas as condições que constam do documento "Esclarecimento ao Paciente", de que trata do Projeto de Pesquisa intitulado "Papel de NF-kB e Notch na regulação de fatores de transcrição durante a diferenciação in vitro de células $\mathrm{T}$ a partir de células progenitoras hematopoéticas CD34 ${ }^{+}$" que tem como pesquisadora responsável a Sra. Josiane Lilian dos Santos Schiavinato, especialmente no que diz respeito ao objetivo da pesquisa, aos procedimentos a que serei submetido, aos riscos e aos benefícios, bem como à ausência de despesas da minha parte, declaro que tenho pleno conhecimento dos direitos e das condições que me foram assegurados, a seguir relacionados:

a) A garantia de receber a resposta a qualquer pergunta ou esclarecimento de qualquer dúvida a respeito dos procedimentos, riscos, benefícios e de outras situações relacionado com a pesquisa e o tratamento a que serei submetido;

b) A liberdade de retirar o meu consentimento e deixar de participar do estudo, a qualquer momento, sem que isso traga prejuízo à continuidade do meu tratamento;

c) A segurança de que não serei identificado e que será mantido o caráter confidencial da informação relacionada à minha privacidade;

d) O compromisso de que me será prestada informação atualizada durante o estudo, ainda que esta possa afetar a minha vontade de continuar dele participando;

e) O compromisso de que serei devidamente acompanhado e assistido durante todo o período de minha participação no projeto, bem como de que será garantida a continuidade do meu tratamento, após a conclusão dos trabalhos de pesquisa.

Declaro ainda que concordo inteiramente com as condições que me foram apresentadas e que livremente manifesto a minha vontade em participar do referido projeto.

Ribeirão Preto, de de

Nome: Assinatura 


\section{Anexo 3}

SONDAS APPLIED BIOSYSTEM

\begin{tabular}{|l|l|}
\hline \multicolumn{1}{|c|}{ Símbolo do Gene } & \multicolumn{1}{c|}{ ID sonda } \\
\hline RELB & Hs00232399_m1 \\
\hline HES1 & Hs00172878_m1 \\
\hline HEY1 & Hs00232618_m1 \\
\hline NF-kB2 & Hs00174517_m1 \\
\hline GATA3 & Hs00231122_m1 \\
\hline RELA & Hs00153294_m1 \\
\hline HOXB4 & Hs00256884_m1 \\
\hline USF1 & Hs00273038_m1 \\
\hline NF-kB1 & Hs00765730_m1 \\
\hline RUNX1 & Hs00231079_m1 \\
\hline
\end{tabular}

